\title{
Data Report for the NRC/PNL Halden Assembly IFA-432: April 1978-May 1980
}

Prepared by E. R. Bradley, M. E. Cunningham, D. D. Lanning, R. E. Williford

Pacific Northwest Laboratory

Operated by

Battelle Memorial Institute

Prepared for

U.S. Nuclear Regulatory

Commission 


\section{NOTICE}

This report was prepared as an account of work sponsored by an agency of the United States Government. Neither the United States Government nor any agency thereof, or any of their employees, makes any warranty, expressed or implied, or assumes any legal liability or responsibility for any third party's use, or the results of such use, of any information, apparatus product or process disclosed in this report, or represents that its use by such third party would not infringe privately owned rights.

Available from

GPO Sales Program

Division of Technical Information and Document Control

U. S. Nuclear Regulatory Commission Washington, D. C. 20555

Printed copy price: $\$ 4.50$

and

National Technical Information Service Springfield, Virginia 22161 


\section{Data Report for the \\ NRC/PNL Halden Assembly IFA-432: April 1978-May 1980}

Manuscript Completed: February 1981

Date Published: April 1981

Prepared by

E. R. Bradley, M. E. Cunningharn, D. D. Lanning, R. E. Williford

Pacific Northwest Laboratory

Richland, WA 99352

\section{Prepared for} Division of Reactor Safety Research Office of Nuclear Regulatory Research U.S. Nuclear Regulatory Commission Washington, D.C. 20555

NRC FIN B2043 


$$
\text { • }
$$




\section{ACKNOWLEDGMENTS}

The authors wish to thank the Fuel Behavior Research Branch, Office of Reactor Safety Research, U.S. Nuclear Regulatory Commission (NRC), for their continued support and encouragement of the experimental program. We also thank the Halden Reactor staff and R. W. Miller, the NRC representative at Halden, for their efforts in recording and transmitting the experimental data. Special thanks are given to W. D. Bennett, who produced the many data plots, and to S. K. Edler for editing this report. 


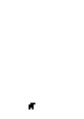




\section{ABSTRACT}

This report presents the in-reactor data collected from the U.S. Nuclear Regulatory Commission (NRC)/Pacific Northwest Laboratory (PNL) Halden test assembly IFA-432 for the period from April 1978 through May 1980. The irradiation test is part of an experimental program entitled "Experimental Support and Development of Single-Rod Fuel Codes" sponsored by the Fuel Behavior Research Branch of the NRC. The purpose of this program is to reduce the uncertainties of predicting the thermal and mechanical behavior of an operating nuclear fuel rod.

Fuel centerline temperatures, cladding elongation, internal fuel rod pressures, and local powers at the thermocouple (TC) positions are shown as a function of time. The local powers were derived from neutron detector readings while the other variables were measured directly.

Detailed analysis of the data is not made, but topical reports discussing certain aspects of the data are referenced. Descriptions of the assembly, instrumentation and calibration, and data processing methods are also presented. 



\section{SUMMARY}

The U.S. Nuclear Regulatory Commission (NRC)/Pacif ic Northwest Laboratory (PNL) Halden test assembly IFA-432 has operated since December 1975 and has reached peak burnups in excess of $2560 \mathrm{GJ} / \mathrm{kgU}(29,600 \mathrm{MWd} / \mathrm{MTM})$ as of May 1980. Data are currently being obtained from six neutron detectors, four fuel thermocouples (TCS), three cladding extensometers, and two pressure transducers. These data are providing valuable information regarding fuel performance at high burnups. The assembly will be removed from the reactor in mid-1981 with projected peak burnups in excess of $3000 \mathrm{GJ} / \mathrm{kgU}(35,000 \mathrm{MWd} / \mathrm{MTM})$.

This report presents in-reactor data collected from IFA-432 for the period from April 1978 through May 1980. Data collected prior to April 1978 were presented in a previous report (Hann et al. 1978b). Fuel temperatures, power levels, and elongation data are presented in the form of plots of the variables versus time while internal pressure data and calculated burnups are tabulated.

Descriptions of the test rationale, assembly and rod designs, test facility, instrument array and calibration, and data processing methods are included. Topical reports discussing specific aspects of the data analys is are referenced. 



\section{CONTENTS}

ACKNOWLEDGMENTS $\quad \cdot \quad \cdot \quad \cdot \quad \cdot \quad \cdot \quad \cdot \quad \cdot \quad \cdot \quad \cdot \quad \cdot \quad \cdot \quad$ •

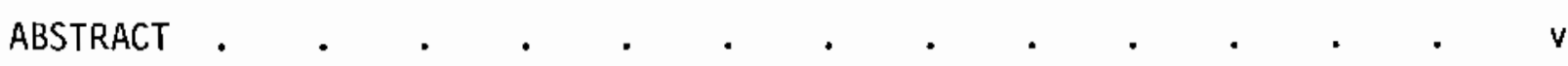
SUMMARY

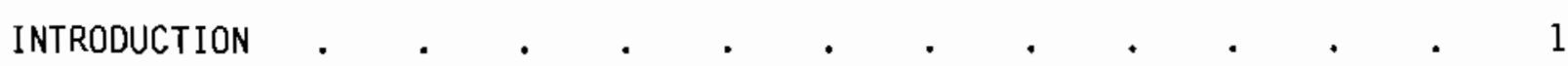

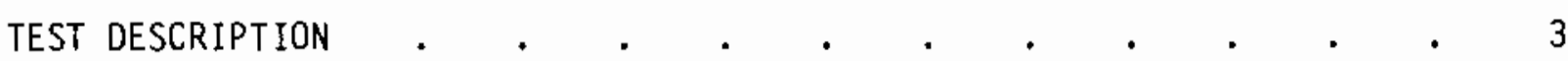
CROSS-CORRELATION EFFORTS . . . . . . . . . . . . 3 TEST FACILITY • • . . . . . . . . . 8

FUEL AND Cladding PREChaRACTERIZATION $\quad . \quad . \quad . \quad . \quad . \quad . \quad 8$ DATA PRESENTATION POWER HISTORIES . . . . . . . . . . . . 13

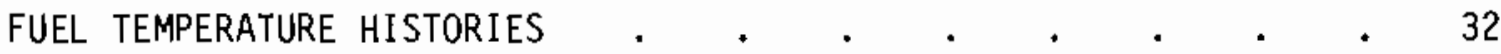
CLADOING ELONGATION HISTORIES . • . . . . . . . 44 ROD INTERNAL PRESSURE HISTORIES . . . . . . . . 54 BURNUP . . . . . . . . . . . . . 62

REFERENCES . . . . . . . . . . . . . . . . 65 APPENDIX A - FUEL ROD AND FUEL COLUMN SCHEMATICS FOR IFA-432 • . A.1 APPENDIX B - DATA PROCESSING APPENDIX C - INSTRUMENT DESCRIPTIONS AND CALIBRATION.$\quad \cdot \quad \cdot \quad$ • C.1

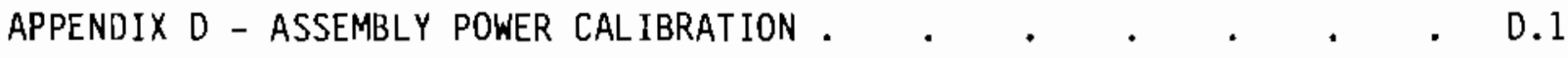




\section{FIGURES}

1 Arrangerient of Temperature Sensors, Neutron Detectors, and Fuel Relative to Reference Axial Thermal Flux Profile . . . 6

2 Schematic of Instrumented Fuel Assembly (IFA)-432 . . . . . 7

3 IFA-431 and IFA-432 Arrangements in the Flow Channel . . . 10

4 Local Linear Heat Ratings at Upper Thermocouple Locations for Rods 1, 2, and 3 of IFA-432 from Apri1 24, 1978, to June 18,1978 . $. \quad . \quad . \quad . \quad . \quad . \quad . \quad . \quad . \quad . \quad 14$

5 Local Linear Heat Ratings at Lower Thermocouple locations for Rods 1, 2 and 3 of IFA-432 from Apri1 24, 1978, to June 18,1978 . $. \quad . \quad . \quad . \quad . \quad . \quad . \quad . \quad 14$

6 Local Linear Heat Ratings at Upper Thermocouple Locations for Rods 5, 6, and 8 of IFA-432 from April 24, 1978, to June 18,1978

7 Local Linear Heat Ratings at Lower Thermocouple Locations for Rods 5, 6, and 8 of IFA-432 from Aprii 24, 1978, to June 18,1978 . $. \quad . \quad . \quad . \quad . \quad . \quad . \quad . \quad 15$

8 Local Linear Heat Ratings at Upper Thermocouple Locations for Rods 1, 2, and 3 of IFA-432 from July 13, 1978, to August 31, 1978

9 Local Linear Heat Ratings at Lower Thermocouple Locations for Rods 1, 2, and 3 of IFA-432 from July 13, 1978, to August 31,1978

10 Local Linear Heat Ratings at Upper Thermocouple Locations for Rods 5, 6, and 8 of IFA-432 from July 13, 1978, to August 31,1978

11 Local Linear Heat Ratings at Lower Thermocouple Locations for Rods 5, 6, and 8 of IFA-432 from July 13, 1978, to August 31,1978

12 Local Linear Heat Ratings at Upper Thermocouple Locations for Rods 1, 2, and 3 of IFA-432 from September 1, 1978,

13 Local Linear Heat Ratings at Lower Thermocouple Locations for Rods 1, 2, and 3 of IFA-432 from September 1, 1978, to October 7, 1978 
14 Local Linear Heat Ratings at Upper Thermocouple Locations

for Rods 5, 6, and 8 of IFA-432 from September 1, 1978, to

October 7, 1978

15 Local Linear Heat Ratings at Lower Thermocouple Locations

for Rods 5, 6, and 8 of IFA-432 from September 1, 1978, to

October 7,1978

16 Local Linear Heat Ratings at Upper Thermocouple Locations

for Rods 1, 2, and 3 of IFA-432 from November 28, 1978, to

January 26,1979

17 Local Linear Heat Ratings at Lower Thermocouple Locations

for Rods 1, 2, and 3 of IFA-432 from November 28, 1978, to

January 26, 1979

18 Local Linear Heat Ratings at Upper Thermocouple Locations

for Rods 5, 6, and 8 of IFA-432 from November 28, 1978, to January 26, 1979

19 Local Linear Heat Ratings at Lower Thermocouple Locations

for Rods 5, 6, and 8 of IFA-432 from November 28, 1978, to January 26, 1979

20 Local Linear Heat Ratings at Upper Thermocouple Locations

for Rods 1,2, and 3 of IFA-432 from Apri] 5, 1979, to

May 22, 1979

21 Local Linear Heat Ratings at Lower Thermocouple Locations

for Rods 1, 2, and 3 of IFA-432 from April 5, 1979, to

May 22, 1979

22 Local Linear Heat Ratings at Upper Thermocouple Locations

for Rods 5, 6, and 8 of IFA-432 from Apr 11 5, 1979, to

May 22, 1979

23 Local Linear Heat Ratings at Lower Thermocouple Locations

for Rods 5, 6, and 81 of IFA-432 from Apri1 5, 1979, to

May 22, 1979

24 Local Linear Heat Ratings at Upper Thermocouple Locations

for Rods 1, 2, and 3 of IFA-432 from July 10, 1979, to

August 23, 1979

25 Local Linear Heat Ratings at Lower Thermocouple Locations

for Rods 1, 2, and 3 of IFA-432 from July 10, 1979, to

August 23, 1979

26 Loca 1 Linear Heat Ratings at Upper Thermocouple Locations

for Rods 5, 6, and 8 of IFA-432 from July 10, 1979, to

August 23, 1979 
27 Local Linear Heat Ratings at Lower Thermocouple Locations for Rods 5, 6, and 8 of IFA-432 from July 10, 1979, to August 23,1979

28 Local Linear Heat Ratings at Upper Thermocouple Locations for Rods 1, 2, and 3 of IFA-432 from October 1, 1979, to November 30,1979

29 Local Linear Heat Ratings at Lower Thermocouple Locations for Rods 1, 2, and 3 of IFA-432 from October 1, 1979, to November 30, 1979

30 Local Linear Heat Ratings at Upper Thermocouple Locations for Rods 5, 6, and 8 of IFA-432 from 0ctober 1, 1979, to November 30,1979

31 Local Linear Heat Ratings at Lower Thermocouple Locations for Rods 5, 6, and 8 of IFA-432 from 0ctober 1, 1979, to November 30, 1979 . $\quad . \quad . \quad . \quad . \quad . \quad . \quad . \quad$. 27

32 Local Linear Heat Ratings at Upper Thermocouple Locations for Rods 1, 2, and 3 of IFA-432 from December 1, 1979, to January 6, 1980

33 Local Linear Heat Ratings at Lower Thermocouple Locations for Rods 1, 2, and 3 of IFA-432 from December 1, 1979, to January 6, 1980

34 Local Linear Heat Ratings at Upper Thermocouple Locations for Rods 5, 6, and 8 of IFA-432 from December 1, 1979, to January 6,1980

35 Local Linear Heat Ratings at Lower Thermocouple Locations for Rods 5, 6, and 8 of IFA-432 from December 1, 1979, to January 6,1980

36 Local Linear Heat Ratings at Upper Thermocouple Locations for Rods 1, 2, and 3 of IFA-432 from March 26, 1980, to May 24, 1980

37 Local Linear Heat Ratings at Lower Thermocouple Locations for Rods 1, 2, and 3 of IFA-432 from March 26, 1980, to May 24,1980

38 Local Linear Heat Ratings at Upper Thermocouple Locations for Rods 5, 6, and 9 of IFA-432 from March 26, 1980, to May 24,1980

39 Local Linear Heat Ratings at Lower Thermocouple Locations for Rods 5, 6, and 9 of IFA-432 from March 26, 1980, to May 24,1980 
40 Upper Thermocouple Readings for Rod 3 of IFA-432 from

April 24, 1978, to June 18,1978 . $. \quad . \quad . \quad . \quad . \quad . \quad 33$

41 Lower Thermocouple Readings for Rods 1, 2, and 3 of IFA-432

from April 24, 1978, to June 18, 1978 . . . . . . 33

42 Lower Thermocouple Readings for Rods 5 and 6 of IFA-432 from

Apri1 24, 1978, to June 18, 1978 . $. \quad . \quad . \quad . \quad . \quad . \quad 34$

43 Upper Thermocouple Readings for Rod 3 of IFA-432 from

July 13, 1978, to August 31,1978 . $\quad . \quad$. . . . $\quad$. 34

44 Lower Thermocouple Readings for Rods 1, 2, and 3 of IFA-432

from July 13,1978 , to August 31,1978 ....$\quad$. 35

45 Lower Thermocouple Readings for Rods 5 and 6 of IFA-432 from

Juiy 13,1978 , to August 31,1978 ..$\quad$. . . . 35

46 Upper Thermocouple Readings for Rod 3 of IFA-432 from

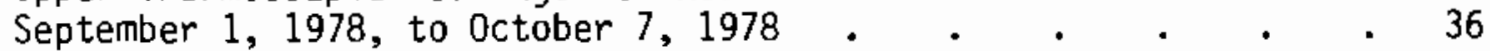

47 Lower Thermocouple Readings for Rods 1, 2, and 3 of IFA-432

from September 1, 1978, to October 7, 1978 . $\quad . \quad$. $\quad . \quad$. 36

48 Lower Thermocouple Readings for Rods 5 and 6 of IFA-432 from

September 1, 1978, to October 7, 1978 . $\quad$. $\quad . \quad$. $\quad$ • 37

49 Upper Thermocouple Readings for Rod 3 of IFA-432 from

November 28,1978 , to January 26,1979 . $\quad . \quad$. . . . 37

50 Lower Thermocouple Readings for Rods 1, 2, and 3 of IFA-432

from November 28,1978 , to January $26,1979 . \quad . \quad . \quad . \quad 38$

51 Lower Thermocouple Readings for Rods 5 and 6 of IFA-432 from November 28,1978 , to January $26,1979 . \quad$. $\quad . \quad$. . 38

52 Lower Thermocouple Readings for Rods 1, 2, and 3 of IFA-432

from April 5, 1979, to May 22, $1979 \quad$. $\quad . \quad . \quad . \quad . \quad . \quad 39$

53 Lower Thermocouple Readings for Rods 5 and 6 of 1FA-432 from April 5, 1979, to May 22, $1979 \quad$. $\quad . \quad . \quad . \quad . \quad . \quad . \quad 39$

54 Lower Thermocouple Readings for Rods 1, 2, and 3 of IFA-432

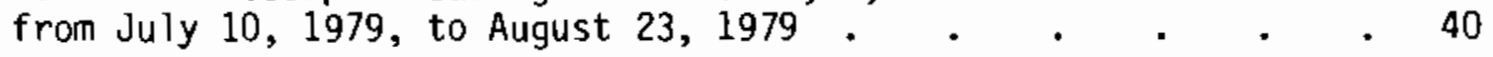

55 Lower Thermocouple Readings for Rods 5 and 6 of IFA-432 from July 10,1979 , to August $23,1979 . \quad \cdot \quad . \quad . \quad . \quad . \quad 40$

56 Lower Thermocouple Readings for Rods 1, 2, and 3 of IFA-432 from October 1, 1979, to November 30, 1979 
57 Lower Thermocouple Readings for Rod 5 of IFA-432 from

October 1,1979 , to November 30,1979 . $\quad$. $\quad$. . . . . 41

58 Lower Thermocouple Readings for Rods 1, 2, and 3 of IFA-432

from December 1, 1979, to January 6, 1980 . . . . . 42

59 Lower Thermocouple Readings for Rod 5 of IFA-432 from

December 1,1979 , to January 6,1980 . . . . . . 42

60 Lower Thermocouple Readings for Rods 1 and 3 of IFA-432 from

March 26, 1980, to May 24, 1980 . . . . . . . 43

61 Lower Thermocouple Readings for Rod 5 of IFA-432 from

March 26, 1980, to May 24, 1980 . . . . . . . 43

62 Cladding Elongation Sensor Readings for Rods 2 and 3 of

IFA-432 from April 24, 1978, to June 18, 1978 . . . . . 45

63 Cladding Elongation Sensor Readings for Rods 6 and 8 of

IFA-432 from Apri1 24, 1978, to June 18, 1978 . . . . 45

64 Cladding Elongation Sensor Readings for Rods 2 and 3 of

IFA-432 from July 13,1978 , to August 31,1978 . . . . 46

65 Cladding Elongation Sensor Readings for Rods 6 and 8 of

IFA-432 from July 13,1978 , to August 31,1978 . . . . 46

66 Cladding Elongation Sensor Readings for Rods 2 and 3 of

IFA-432 from September 1, 1978, to October 7, 1978 . . . 47

67 Cladding Elongation Sensor Readings for Rods 6 and 8 of IFA-432 from September 1, 1978, to October 7, 1978 . . . 47

68 Cladding Elongation Sensor Readings for Rods 2 and 3 of

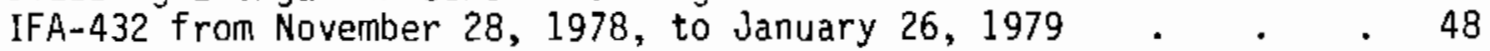

69 Cladding Elongation Sensor Readings for Rods 6 and 8 of IFA-432 from November 28,1978 , to January 26,1979 . . . . 48

70 Cladding Elongation Sensor Readings for Rod 2 of IFA-432 from April 5, 1979, to May 22, 1979 . . . . . . . 49

71 Cladding Elongation Sensor Readings for Rods 6 and 8 of IFA-432 from April 5, 1979, to May 22, 1979 . . . . . .

72 Cladding Elongation Sensor Readings for Rod 2 of IFA-432 from July 10,1979 , to August 23,1979 . . . . . . . 50

73 Cladding Elongation Sensor Readings for Rods 6 and 8 of IFA-432 from July 10, 1979, to August 23, 1979 . . . . . . 50 
74 Cladding Elongation Sensor Readings for Rod 2 of IFA-432 from

October 1, 1979, to November 30, 1979 . . . . . . . 51

75 Cladding Elongation Sensor Readings for Rods 6 and 8 of IFA-432

from October 1, 1979, to November 30, 1979 . $\quad . \quad$. $\quad$. 51

76 Cladding Elongation Sensor Readings for Rod 2 of IFA-432 from

December 1, 1979, to January 6, 1980 ....$\quad$. 52

77 Cladding Elongation Sensor Readings for Rods 6 and 8 of IFA-432

from December 1, 1979, to January 6, 1980 . $. \quad . \quad . \quad$. 52

78 Cladding Elongation Sensor Readings for Rod 2 of IFA-432 from

March 26, 1980, to May 24, 1980 ...... .53

79 Cladding Elongation Sensor Readings for Rod 9 of IFA-432 from

March 26, 1980, to May 24, 1980 . $. \quad . \quad . \quad . \quad . \quad . \quad 53$

A.1 Schematic Arrangement of Fue I Rods for IFA-432 . . . . A.2

A.2 Stack Arrangement for Rods 1 and 6 of IFA-432 . . . . A.3

A.3 Stack Arrangement for Rods 2, 3, and 5 of IFA-432 . . . . . A.4

A.4 Stack Arrangement for Rod 2 of IFA-432 . . . . . . . . A.5

A.5 Stack Arrangement for Rod 4 of IFA-432 (Xenon Fill Gas) - . A.6

A.6 Stack Arrangement for Noninstrumented Replacement Rods
7,8 , and 9 of IFA-432 . . . . . . . . . . . . . . . . .

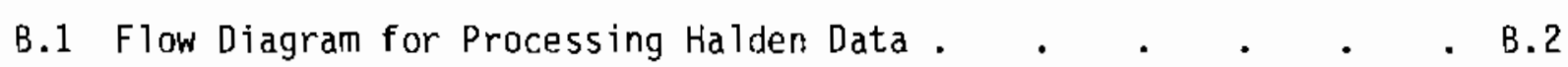

C.1 Schematic of Self-Powered Beta Current Neutron Detector . . C.2

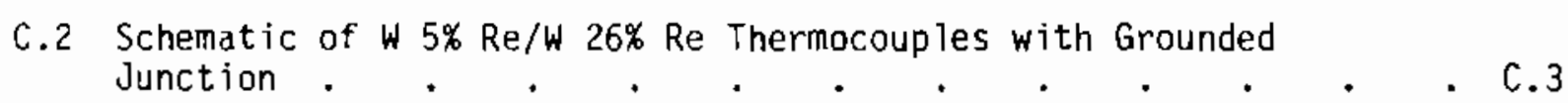

C.3 Calibration Curve for $\mathrm{W} 5 \% \mathrm{Re} / \mathrm{W} 26 \%$ Re Thermocouples . . . . C.4

C.4 Cladding Elongation Monitor . . . . . . . . . . . . C.6

C.5 Fission Gas Pressure Transducer . . . . . . . . . . . C.7 


\section{TABLES}

1 Design Parameters and Instrumentation for IFA-432 . . . . 4

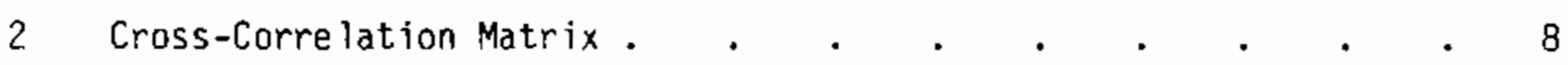

3 Operating Data for the Halden Boiling Water Reactor . . . 9

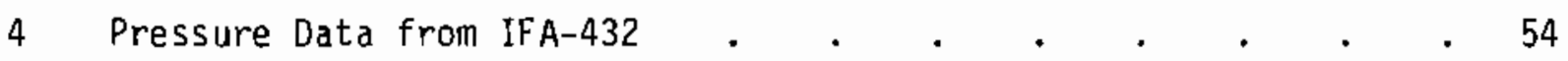

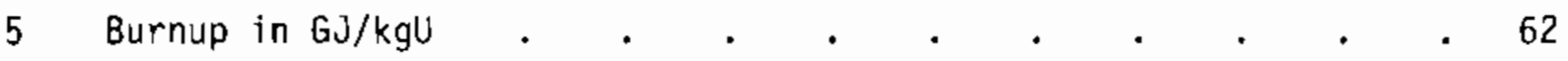




\section{INTRODUCTION}

The thermal stored energy in a fuel rod is the driving function for the severest postulated nuclear energy-related accident--the loss-of-coolant accident (LOCA). Because of this, the final acceptance criteria for emergency core cooling (ECC) systems require calculation of the stored energy and gap conductance of a fuel rod, both for normal operation and for the duration of the LOCA. Although these calculations are used in the regulation of commercial nuclear power plants, uncertainties in them have caused temporary derating of many power plants and delays in the startup of other plants. Many of these uncertainties can be attributed to the lack of well-characterized data for fuel irradiated throughout the normal operating power range of commercial nuclear power plants.

To focus on these uncertainties, four instrumented fuel assemblies (IFAs) have been designed by the Pacific Northwest Laboratory (PNL) ${ }^{(a)}$ and are being irradiated in the boiling water reactor (BWR) at Halden, Nowway. The first two tests in the series are IFA-431 and IFA-432, which are identical 6-rod assemblies containing the same varjations of gap size and fuel type but operating at different power levels. IFA-513 is the third assembly in the series and contains six identical rods except for fill gas composition and pressure. The fourth assembly, IFA-527, uses xemon for the fill gas to study the effects of fuel pellet cracking and relocation. The subject of this report is IFA-432, the second assembly, which had a design power of $49 \mathrm{~kW} / \mathrm{m}(15 \mathrm{~kW} / \mathrm{ft})$ and reached its goal burnup of $1720 \mathrm{GJ} / \mathrm{kgU}(20,000 \mathrm{MWd} / \mathrm{MTM})$ in late 1978 . However, since most of the instruments in IFA-432 were still functioning properly at that time, it was left in the Halden core to obtain data at higher burnups.

IFA-432 has provided a vast amount of we11-characterized experimental data under conditions that realistically simulate light water reactor (LWR) conditions. The data have been used extensively for analyzing fission gas release

(a) Operated for the U.S. Department of Energy (DOE) by Battelle Memorial Institute. 
(Bradley et al. 1979a; Bradley et al. 1979b) and thermal and mechanical fuel rod performance (Lanning, Barnes, and Williford 1979; Lanning, Barnes, and Sheffler 1980; Williford and Hann 1977; Cunningham, Williford, and Hann 1979; Hann and Marshall 1977; and Wilififord et al. 1980) and for estimating error propagation in stored energy calculations (Cunningham et al. 1978). As a result of the data analysis, improved models for computer code calculations of fue 1 rod performance in LWRs are being developed.

The experimental data collected for IFA-432 from startup through January 1978 were reported previously by Hann et al. (1978b). This report presents the experimental data collected from April 1978 through May 1980. (a)

(a) The reactor was shut down from January 1978 to April 1978. 


\section{IEST DESCRIPTION}

Experimental verification of computer codes provides a means to quantify uncertainties in simulating the conditions for an operating nuclear fuel rod. A collection of mathematical models (i.e., a computer code) is used to simulate the wide range of conditions postulated during an evaluation of reactor fuel safety. Any computer code that is forced to rely on a collection of empirical and semiempirical models for much of the analysis is limited and should be primarily used for interpolation. Some extrapolation can be accomplished with mode1s based on first principles; however, well-characterized data are needed in either case to test code predictions. When this program began in July 1974, very little data were available describing the effects of burnup on LWR fuel and no data were available describing the effects of fuel densification on fuel temperatures. Accordingly, a test matrix was developed (see Table 1), and two IFAs were designed to provide the data. (a)

\section{CROSS-CORRELATION EFFORTS}

Much thought went into the design of this test in order to:

- insure a means for cross-correlating the data

- provide as many independent checks of data validity as possible

- insure against instrument failure

- insure at least internal consistency on a relative basis

- provide some reference points to comnercial plant designs and other fue 1 research programs.

One of the basic premises of the test design was to provide a systematic approach that would allow adequate interpolation and extrapolation with computer codes. The first step in this approach was the decision to begin with two identical assemblies since this would enhance the ability to interpolate

(a) IFA-432 and IFA-431 are identically designed assemblies; IFA-431 was irradiated from June 1975 to February 1976 (Hann et al. 1978a; Nealley et al. 1979). 
TABLE 1. Design Parameters and Instrumentation for IFA-432

IFA-432 [Peak Power - $492 \mathrm{~W} / \mathrm{cm}(15 \mathrm{~kW} / \mathrm{ft})]$

\begin{tabular}{|c|c|c|c|c|c|c|c|c|c|c|c|}
\hline \multirow[b]{2}{*}{$\begin{array}{l}\text { Rod } \\
\text { No. }\end{array}$} & \multirow{2}{*}{\multicolumn{2}{|c|}{$\begin{array}{c}\text { Diameter } \\
\text { Pellet }\end{array}$}} & \multirow{2}{*}{\multicolumn{2}{|c|}{$\begin{array}{c}\text { Cold } \\
\text { Diametral } \\
\text { Gap }(a)\end{array}$}} & \multirow{2}{*}{\multicolumn{2}{|c|}{$\begin{array}{l}\text { Fue } 1 \\
\text { Density, } \\
\% \text { TD }\end{array}$}} & \multirow[b]{2}{*}{$\begin{array}{l}\text { Fue } \\
\text { Type }\end{array}$} & \multicolumn{4}{|c|}{ Instrumentation } \\
\hline & & & & & & & & $\frac{\text { Temper }}{\text { Upper }}$ & $\frac{\text { ature }}{\text { Lower }}$ & Press & $\begin{array}{c}\text { Cladding } \\
\text { Length }\end{array}$ \\
\hline$\overline{1}$ & $\overline{10.681}$ & 0.4205 & $\overline{0.229}$ & 0.009 & $\mathrm{He}$ & 95 & Stable & $\overrightarrow{T C}(\mathrm{C})$ & TC & $\mathrm{PT}^{\mathrm{T}}$ & $\mathrm{ES}^{(\mathrm{e})}$ \\
\hline 2 & 10.528 & 0.4145 & 0.381 & 0.015 & $\mathrm{He}$ & 95 & Stable & $U T^{(f)}$ & TC & -- & ES \\
\hline 3 & 10.833 & 0.4265 & 0.076 & 0.003 & $\mathrm{He}$ & 95 & Stable & $\mathrm{TC}$ & TC & -- & ES \\
\hline 4 & 10.681 & 0.4205 & 0.229 & 0.009 & $x_{e}$ & 95 & Stable & $T C$ & TC & -- & ES \\
\hline 5 & 10.681 & 0.4205 & 0.229 & 0.009 & $\mathrm{He}$ & 92 & Stable & TC & TC & PT & ES \\
\hline 6 & 10.681 & 0.4205 & 0.229 & 0.009 & $\mathrm{He}$ & 92 & Unstable & $T C$ & TC & PT & ES \\
\hline 7 & 10.528 & 0.4145 & 0.381 & 0.015 & $\mathrm{He}$ & 95 & Stable & -- & - & -- & -- \\
\hline 8 & 10.681 & 0.4205 & 0.229 & 0.009 & $\mathrm{He}$ & 95 & Stable & -- & -. & - & - \\
\hline 9 & 10.732 & 0.4225 & 0.179 & 0.007 & $\mathrm{He}$ & 95 & Stable & -- & -- & -- & -- \\
\hline
\end{tabular}

(a) Cladding for all rods has an 00 of $12.789 \mathrm{~mm}(0.5035 \mathrm{in.})$ and an ID of $10.909 \mathrm{~mm}(0.4295 \mathrm{in.}$. Diametral gap is cladding ID minus pellet diameter.

(b) With respect to in-reactor densification.

(c) TC = Thermocoup $1 \mathrm{e}$

(d) $\mathrm{PT}=$ Pressure Transducer

(e) $E S=$ Elongation Sensor

(f) UT = Ultrasonic Thermometer 
over a range of powers and replicate initial conditions, (For example, all the data from the first power ramp of IFA-431 were duplicated with IFA-432.) Uncertainties associated with assembly and rod power distributions would also be reduced with identically designed assemblies.

The power profile in the Halden BWR (Figure 1) was also considered during the design. The top of the rods was placed at the peak, which forced the bottom of the rods to operate at $70-80 \%$ of peak rod power. To take advantage of the power distribution, thermocouples (TCs) were placed in the top and bottom of each rod. No tests had ever been run at Haiden with TCs penetrating both end caps; however, Halden staff were able to develop a workable design. TCs in both ends allow modelers to check the ability of various codes to extrapolate over a short power range within the same rod. If a code cannot perform these calculations adequately, calculations of the temperature distribution over a 4-m fuel length are also suspect.

Reference points with commercial plants and other fuel research programs were also developed by selecting a BWR-6 fuel geometry, procuring commercialquality tubing, and selecting appropriate assembly powers. Some of the cladding procured for this program was shipped to EG\&G-Idaho National Engineering Laboratory (INEL) for use in their Halden tests. Both programs (PNL and INEL) also used the same starting powder for fuel manufacture. Some of the fuel structures were similar to those investigated in the Edison Electric Institute/ Electric Power Research Institute (EEI/EPRI) $\mathrm{UO}_{2}$ fuel densification study (Brite et al. 1975) to provide a reference point to a much larger structural characterization program.

The correct assessment of rod powers and the distribution of power within the rods are of utmost importance to assure the best possible thermal data. Therefore, seven neutron sensors were placed in each assembly (Figure 2): one cobalt detector in the center, three vanadium detectors at the top plane of the $T C s$, and three vanadium detectors at the bottom plane of the TCs. An extensive calibration of the vanadium sensors was conducted during the initial startup of any assembly. In addition, rod $3(0.076-m m$ diametral gap) was included as an internal standard. The small gap is closed at power; thus, the temperature gradient across the gap is minimized. Since the coolant temperature and fuel 


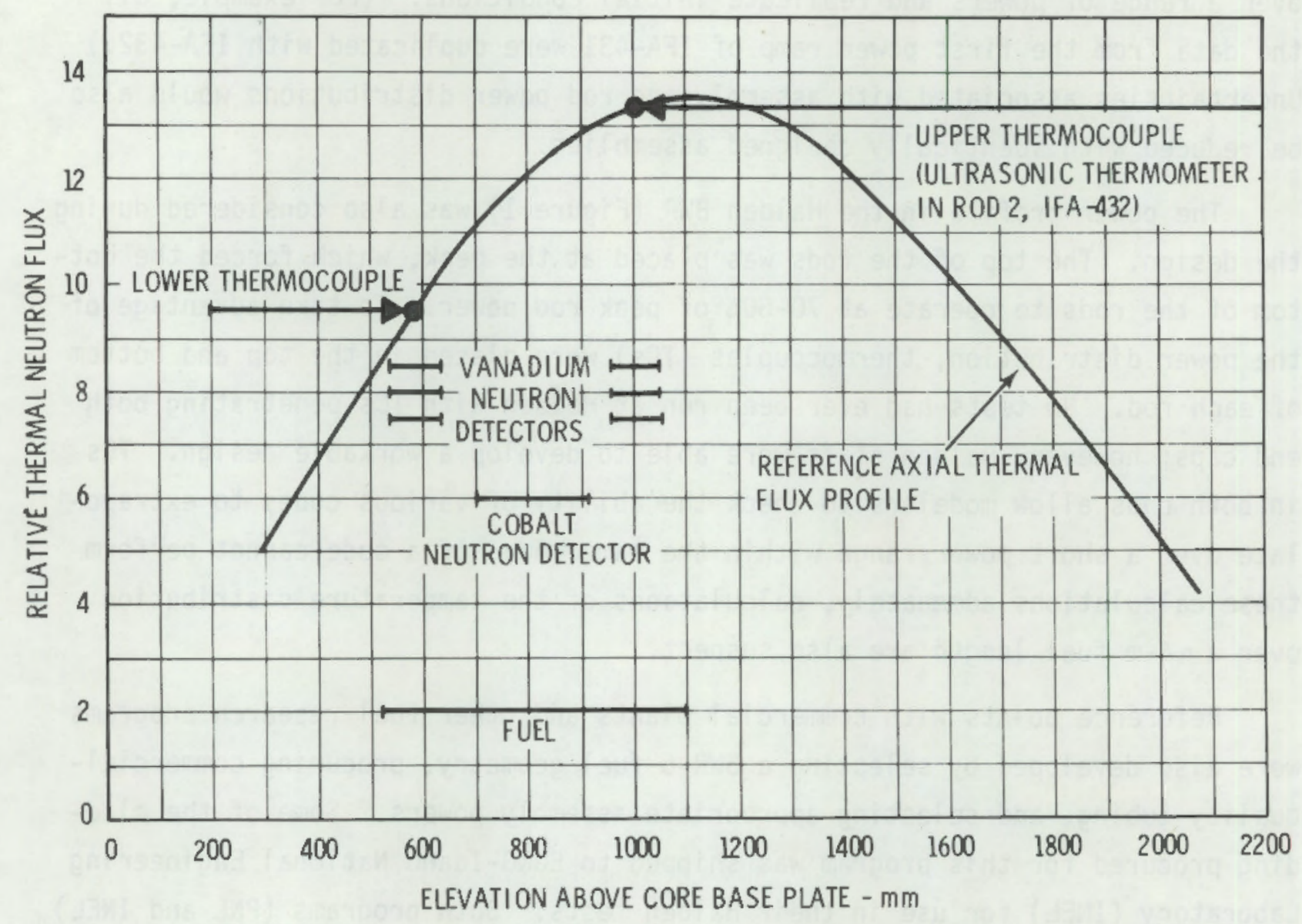

FIGURE 1. Arrangement of Temperature Sensors, Neutron Detectors, and Fuel Relative to Reference Axial Thermal Flux Profile

centerline temperatures are known, an independent check of rod power at both the top and bottom planes in the assembly can be obtained. Rod powers and fue 1 temperatures in both assemblies have been compared to assure consistent data. Each rod has a cladding elongation sensor; rods 1, 5, and 6 also have null balance fission gas pressure transducers (PXDs).

Table 2 illustrates the amount of cross-correlation that is possible. In addition to the rod-to-rod comparisons, top-to-bottom comparisons can be made in each rod, and separate effects as a function of burnup and power can be evaluated. 


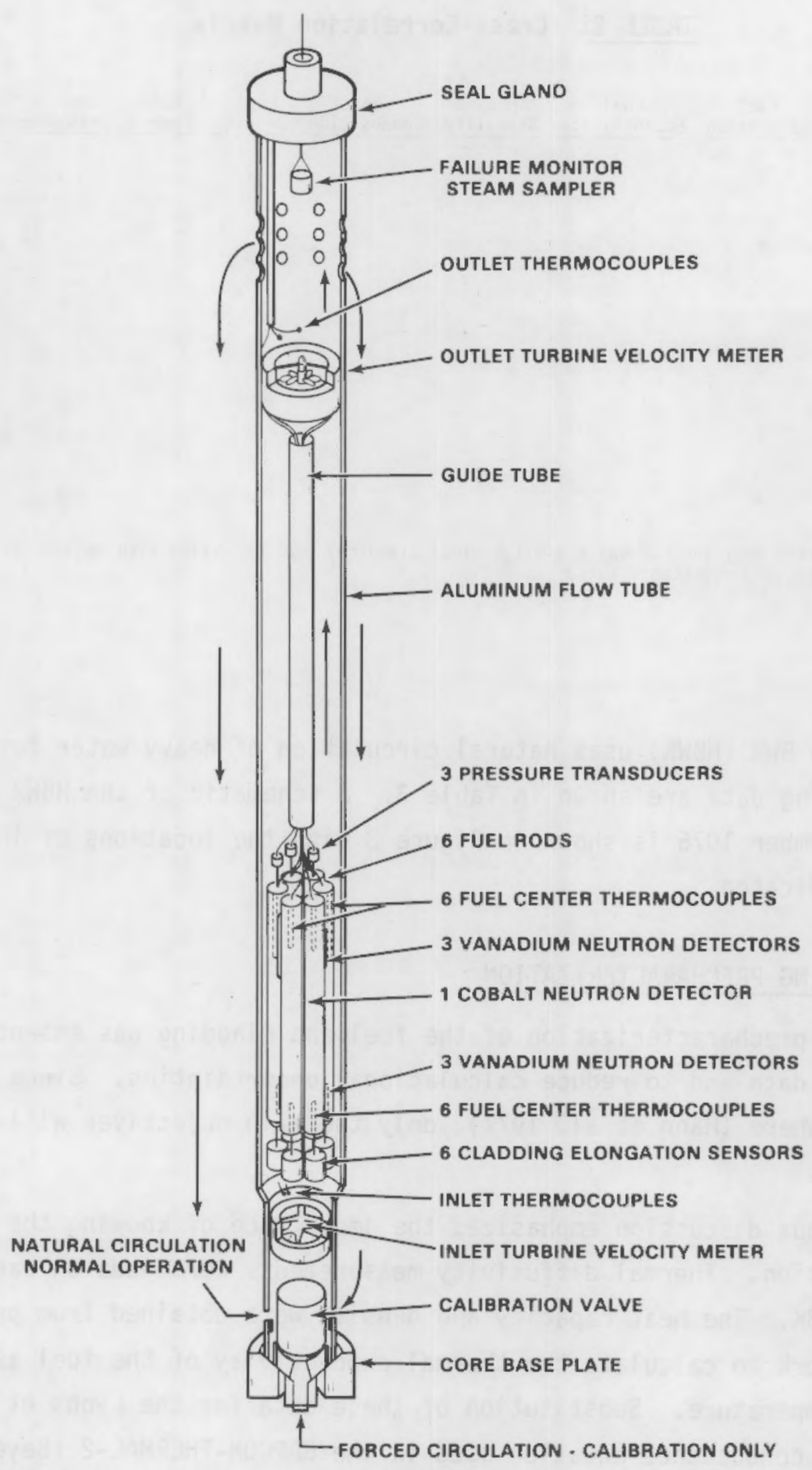

FIGURE 2. Schematic of Instrumented Fuel Assembly (IFA)-432 


\section{TABLE 2. Cross-Correlation Matrix}

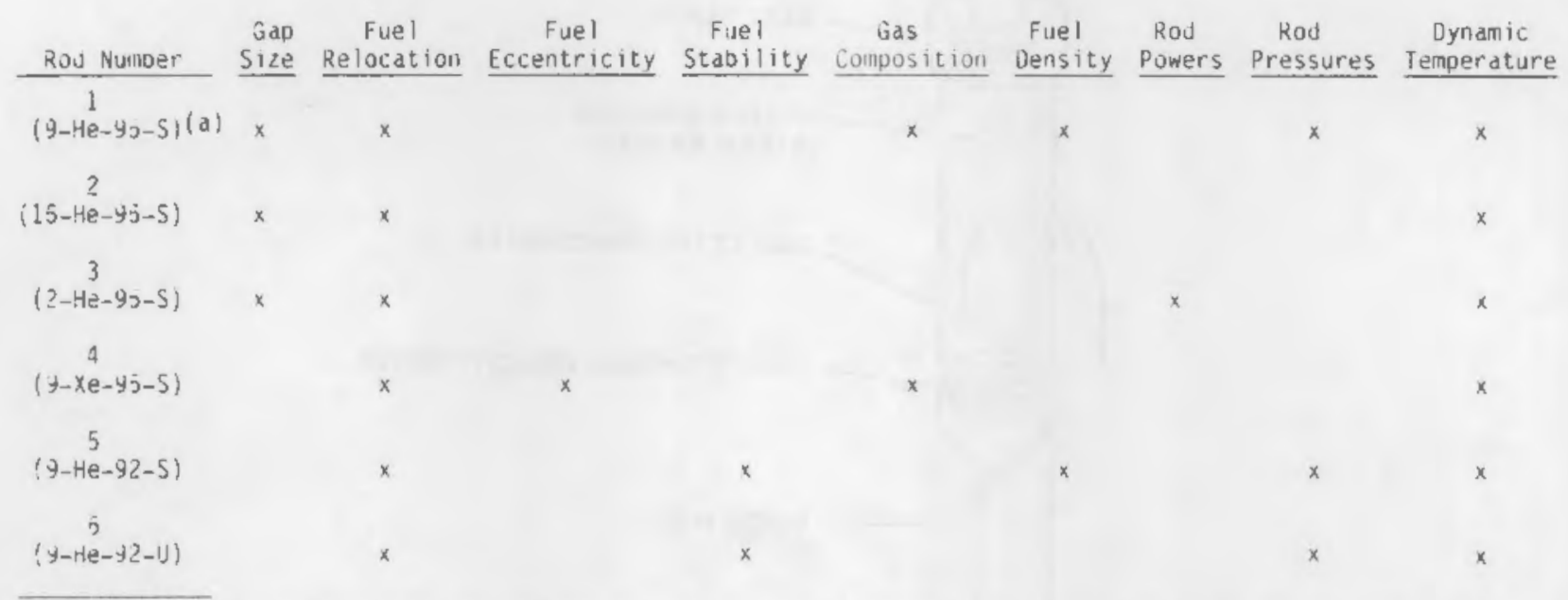

(a) $(9-H e-95-5)$ indicates that the rod nas a $9-m i l$ nominal diametral gap, is filled witn nelium, nas a $95 \%$
theoretical density, and nas stable fuel.

\section{TEST FACILITY}

The Halden BWR (HBWR) uses natural circulation of heavy water for cooling. Reactor operating data are shown in Table 3. A schematic of the HBWR core loading in November 1975 is shown in Figure 3 with the locations of IFA-431 and IFA-432 indicated.

\section{FUEL AND CLADDING PRECHARACTERIZATION}

Extensive precharacterization of the fuel and cladding was essential to assure quality data and to reduce calculational uncertainties. Since this is presented elsewhere (Hann et al. 1977), only the main objectives will be discussed here.

The previous discussion emphasized the importance of knowing the correct power distribution. Thermal diffusivity measurements were made on each fuel type up to $1873 \mathrm{~K}$. The heat capacity and density were obtained from previous experimental work to calculate the thermal conductivity of the fuel as a function of temperature. Substitution of these data for the Lyons et al. (1964) thermal conductance equation used in the GAPCON-THERMAL-2 (8eyer et al. 1975) pretest predictions improved the power calibration calculation using 
TABLE 3. Operating Data for the Halden Boiling Water Reactor

$\begin{array}{ll}\text { Power Level } & 12 \mathrm{MW} \\ \text { Reactor Pressure } & 3.4 \mathrm{MPa}(500 \mathrm{psi}) \\ \text { Heavy Water Saturation Temperature } & 513 \mathrm{~K}\left(464^{\circ} \mathrm{F}\right) \\ \text { Plenum Inlet Temperature } & 510 \mathrm{~K}\left(459^{\circ} \mathrm{F}\right) \\ \text { Thermal Flux } & \sim 2 \times 10^{16} \mathrm{n} / \mathrm{m}^{2}-\mathrm{s} /(\mathrm{W} / \mathrm{g}) \\ \text { Fast Flux }(>1 \mathrm{MeV}) & \sim 5 \times 10^{15} \mathrm{n} / \mathrm{m}^{2}-\mathrm{s} /(\mathrm{W} / \mathrm{g}) \\ \text { Average Fuel Power Density } & 14.8 \mathrm{~W} / \mathrm{g}\end{array}$

rod 3. However, after the first rise to power that produces fuel cracking, the Lyons formulation for the thermal conductance is believed to be more applicable.

Establishing the initial dimensions and void volumes within the pins was also an essential part of assessing all thermal calculations; consequently, the lengths and diameters of each pellet and the cladding for each rod were measured. Each pellet was identified with a unique number to trace pellet types and position within the rod (see Appendix A). With this information the axial distribution of gap volume and the plenum volume were obtained with considerable accuracy. Pellet and cladding roundness profiles were also obtained to illustrate the departure from ideal coaxial cylinders used in most computer code models.

Geometric densities were determined for all pellets, and immersion densities were determined for a significant fraction of the pellets. A correlation was developed relating immersion density to geometric densities. These data were used in two ways: in the correction to rod powers caused by differences in mass distribution and in the verification of U.S. Nuclear Regulatory Commission (NRC) resintering models used to characterize the propensity of the fuel to densify. Resintering tests conducted on each fuel type are discussed in Hann et al. (1977).

The EEI/EPRI UO ${ }_{2}$ densification program demonstrated the importance of pore-size distribution measurements in characterizing the stability of various fue 1 types. Therefore, the pore-size distributions of the three fuel types 


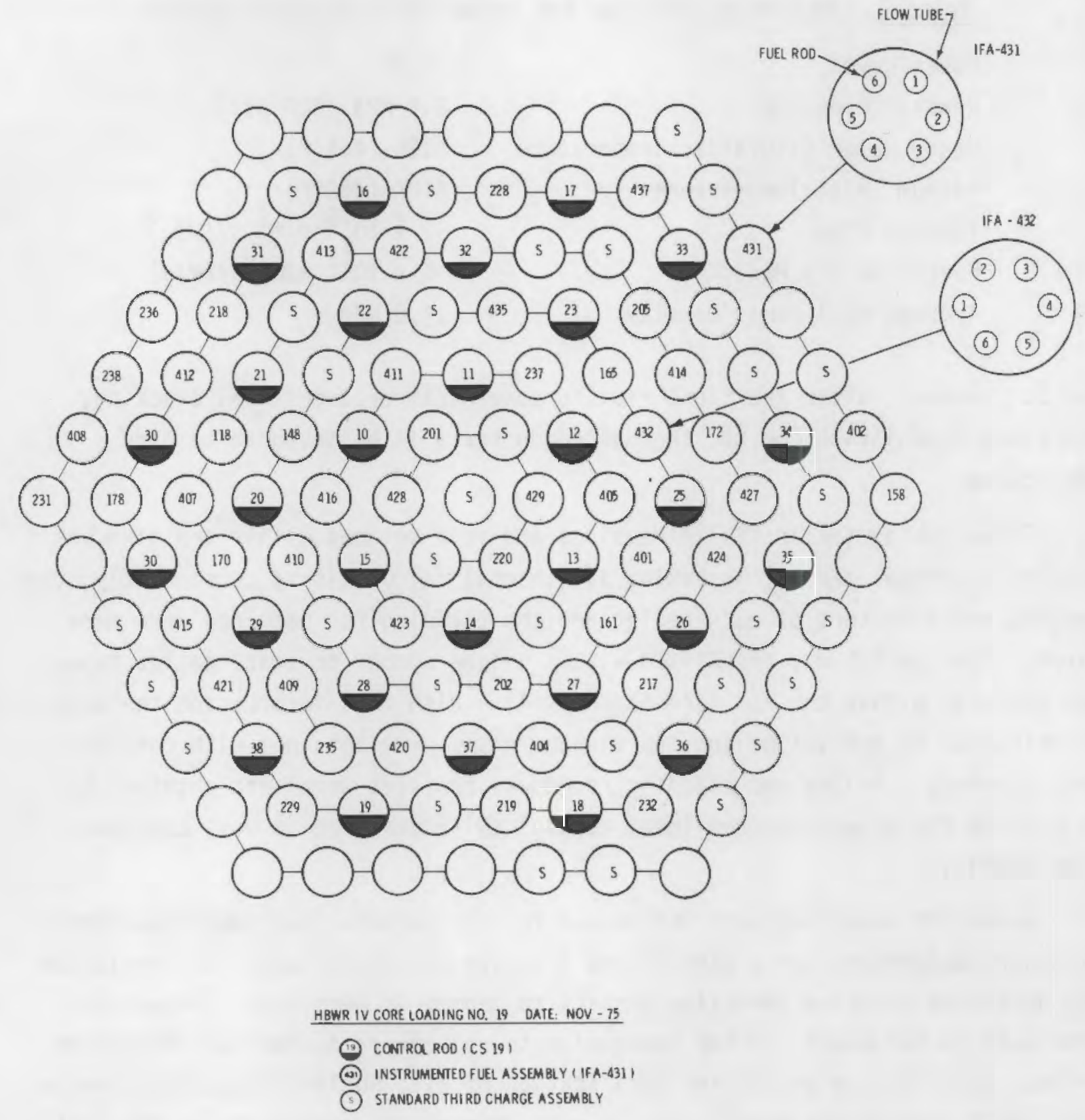

FIGURE 3. IFA-431 and IFA-432 Arrangements in the Flow Channel 
used in these experiments were measured prior to irradiation to assure that the desired response to irradiation would be achieved. Both fuel densities and pore-size distribution will be measured during postirradiation examination (PIE) for rods 1, 5, and 6 at Harwe 11, UK. Archive pellets from each fuel type were retained to provide a means of reducing variances associated with potential differences in examination techniques used in the pre- and post-test measurements. 



\section{DATA PRESENTATION}

In-reactor data collected from IFA-432 by the Halden IBM/1800 on- 7 ine computer data acquisition system for the period from April 1978 through May 1980 are presented in this section. Linear heat generation rates, fuel temperatures, and cladding elongation data are plotted as a function of time. In each plot, the rod number for each curve appears in the upper left-hand corner. The relative position of the rod number corresponds to the relative position of the curve in each figure. Rod 8 is a noninstrumented rod that replaced rod 4 following its removal at the end of February 1976. Rod 8 was replaced by rod 9 in February 1980.

Internal pressure data were taken manually and are presented in tabular form along with the moderator temperature and the reactor and assembly power levels. All of the pressure data taken since the initial startup (December 1975) are presented. The calculated burnup of the upper and lower TC locations are also given on a monthly basis.

\section{POWER HISTORIES}

Power histories for the upper and lower TC locations for all six rods are presented in Figures 4 through 39 . These values were deduced from the vanadium self-powered neutron detector (SPND) readings after applying correction factors to account for local mass distribution, radial flux tilt, and axial flux shape (see Appendix B).

Corrections were also made for the burnup-dependent depletion of ${ }^{235} \mathrm{U}$. The correction that was used $(-0.66 \%$ per $1000 \mathrm{MWd} / \mathrm{MTM})$ was taken from depletion calculations performed at Halden.

The neutron detector readings during transient periods have not been corrected for the response lag of the detector caused by incomplete saturation of the vanadium emitter. This lag amounts to about 5 min during a power ramp or one-third of the normal data collection frequency. 


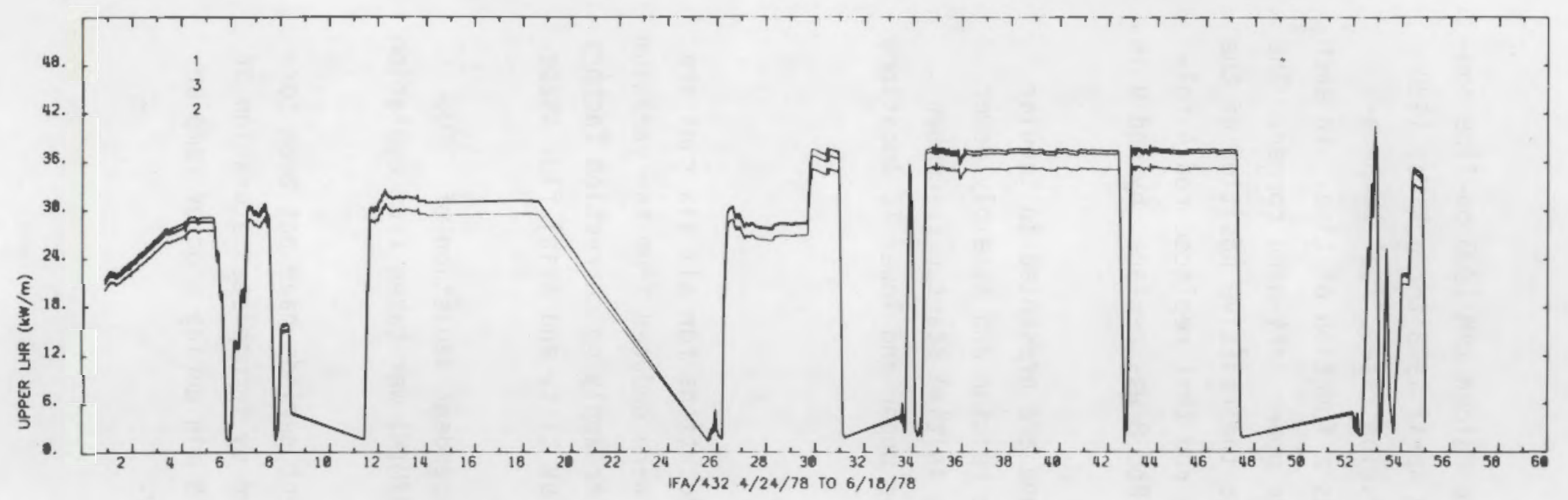

FIGURE 4. Local Linear Heat Ratings at Upper Thermocouple Locations for Rods 1, 2, and 3 of IFA-432 from April 24, 1978, to June 18, 1978

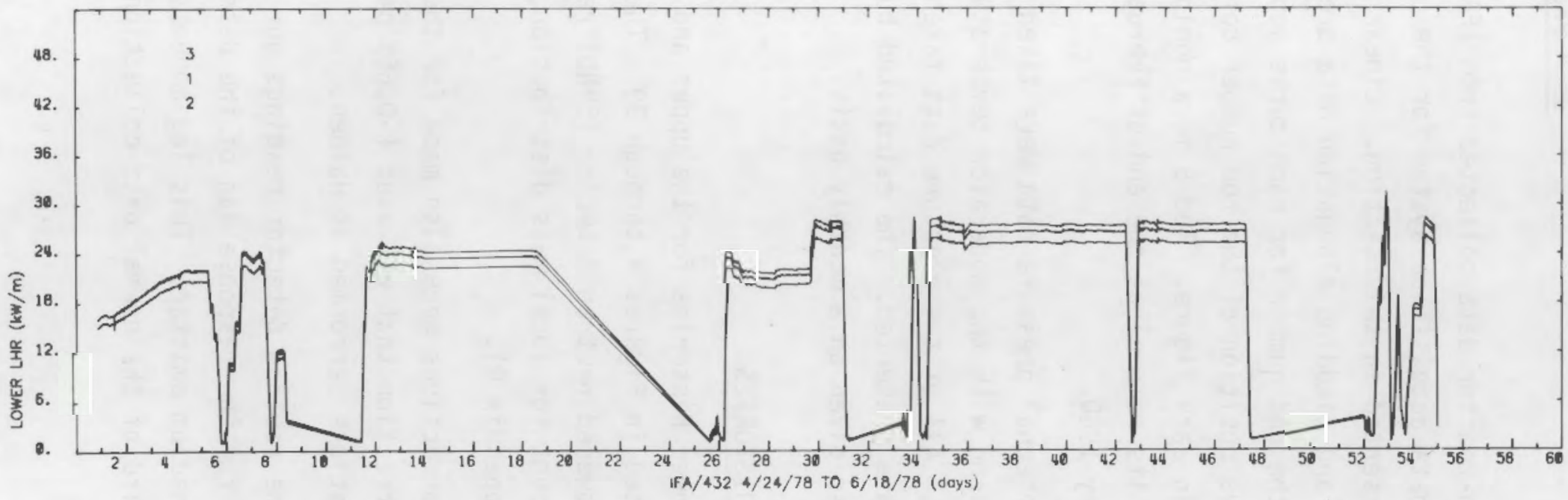

FIGURE 5. Local Linear Heat Ratings at Lower Thermocouple Locations for Rods 1,2 and 3 of IFA-432 from April 24, 1978, to June 18, 1978 


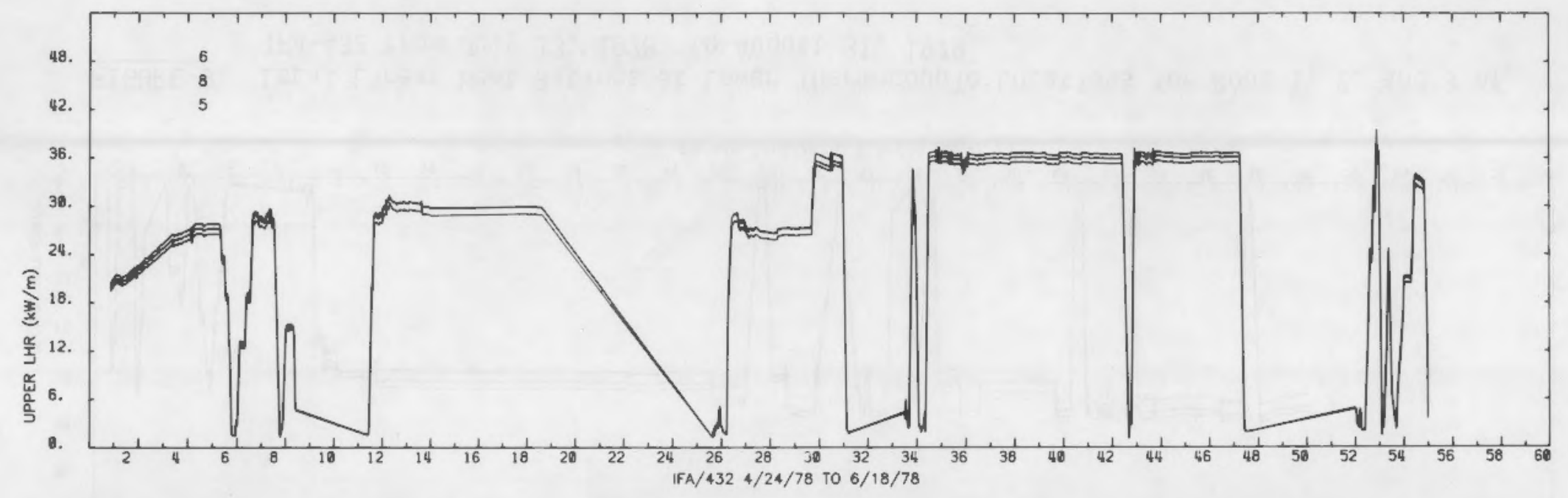

FIGURE 6. Local Linear Heat Ratings at Upper Thermocouple Locations for Rods 5, 6, and 8 of IFA-432 from April 24, 1978, to June 18, 1978

它

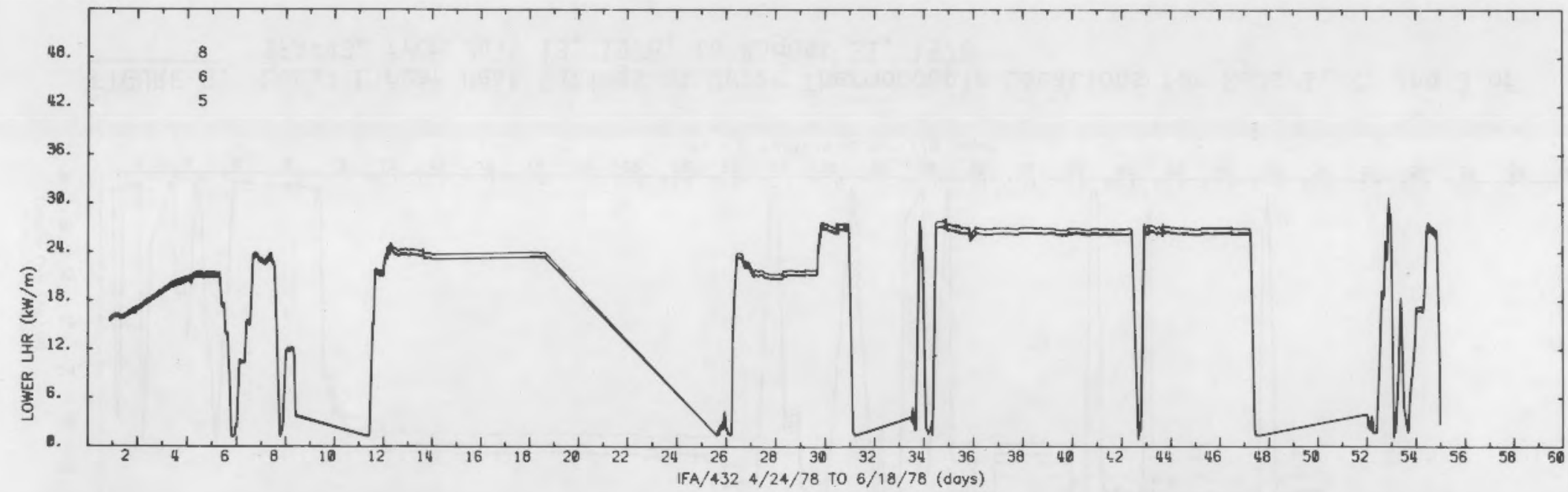

FIGURE 7. Local Linear Heat Ratings at Lower Thermocouple Locations for Rods 5,6 , and 8 of IFA-432 from April 24, 1978, to June 18, 1978 


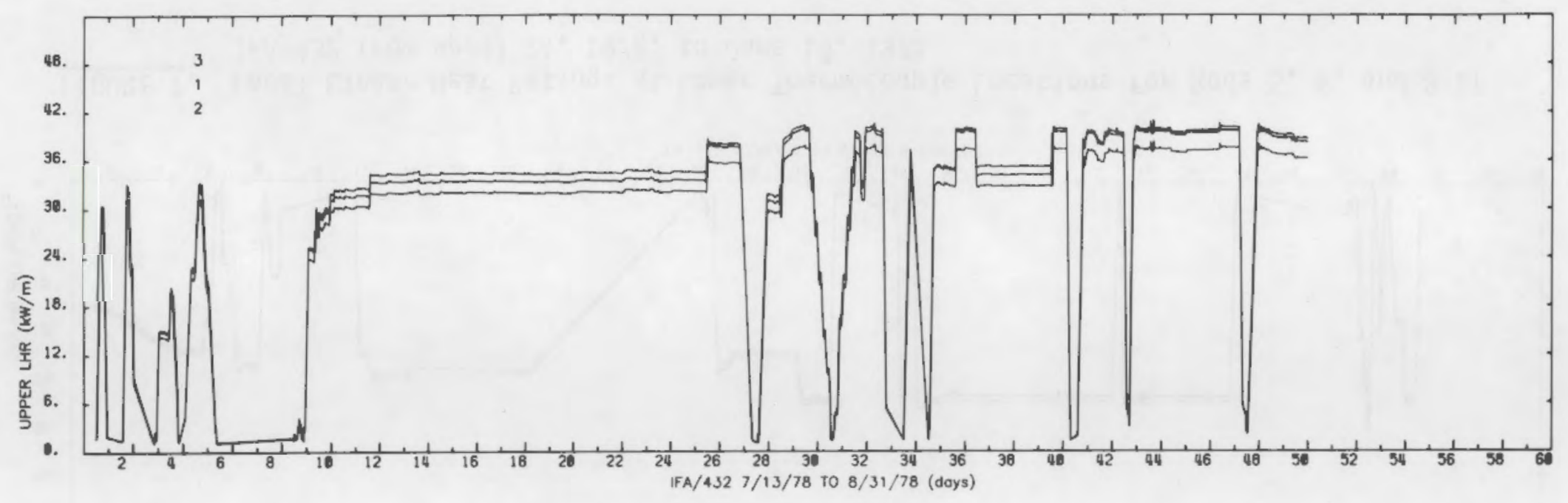

FIGURE 8. Local Linear Heat Ratings at Upper Thermocouple Locations for Rods 1, 2, and 3 of IFA-432 from July 13, 1978, to August 31,1978

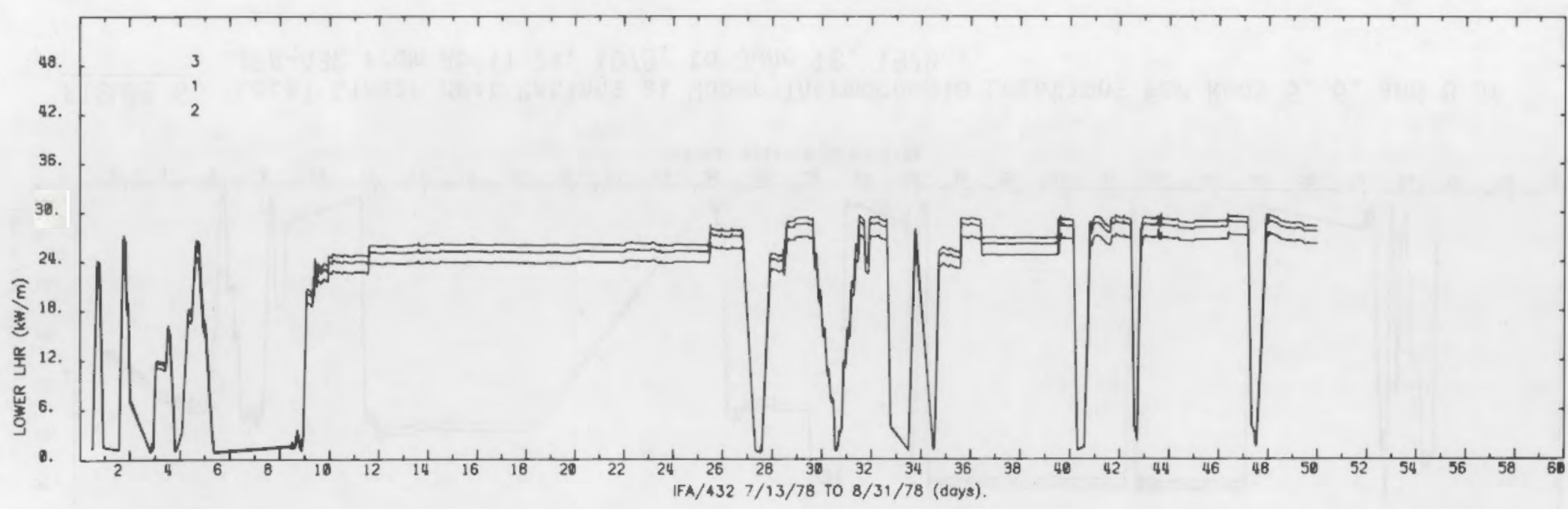

FIGURE 9. Local Linear Heat Ratings at Lower Thermocouple Locations for Rods 1, 2, and 3 of IFA-432 from July 13, 1978, to August 31,1978 


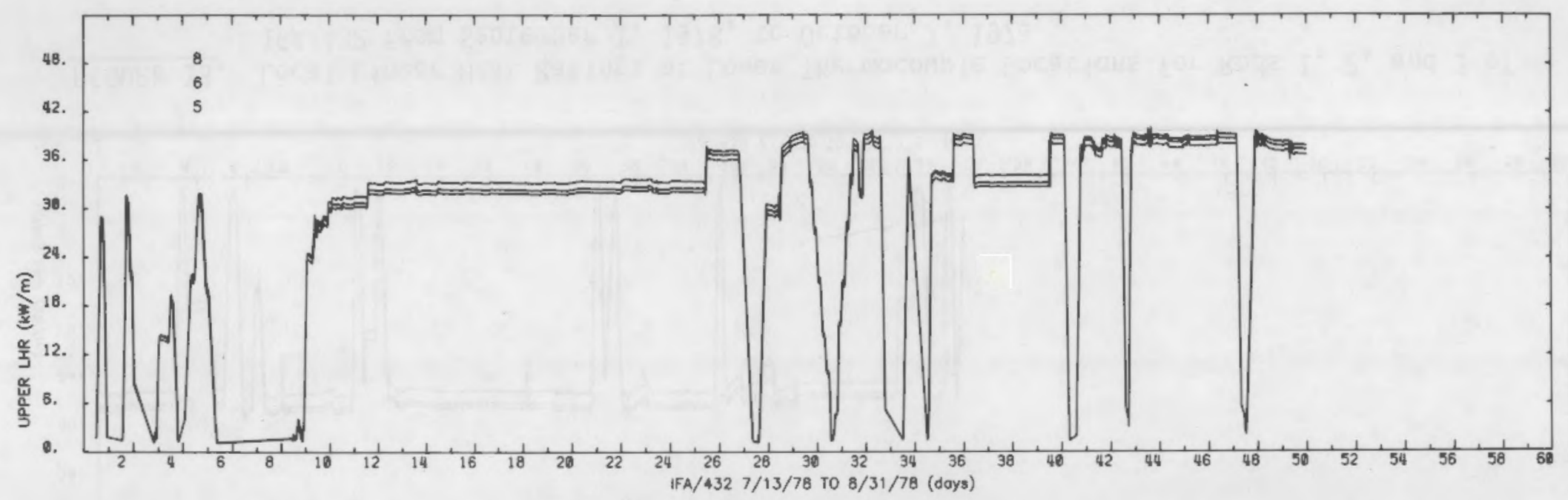

FIGURE 10. Local Linear Heat Ratings at Upper Thermocouple Locations for Rods 5, 6 , and 8 of IFA-432 from July 13, 1978, to August 31, 1978

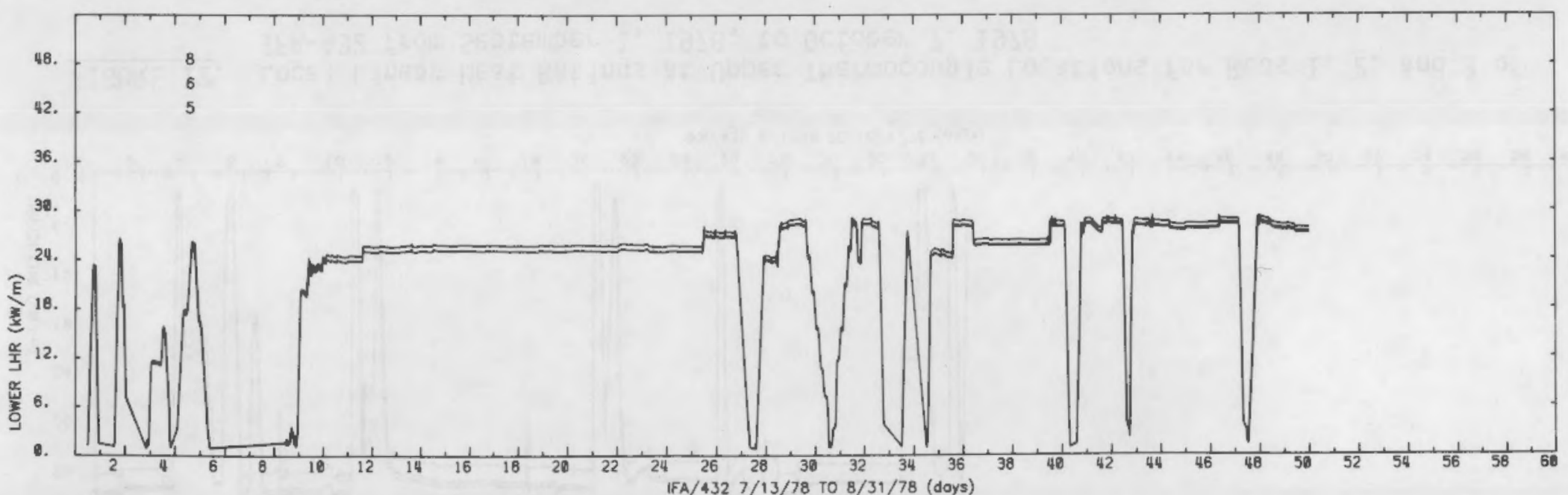

FIGURE 11. Local Linear Heat Ratings at Lower Thermocouple Locations for Rods 5, 6, and 8 of IFA-432 from July 13, 1978, to August 31,1978 


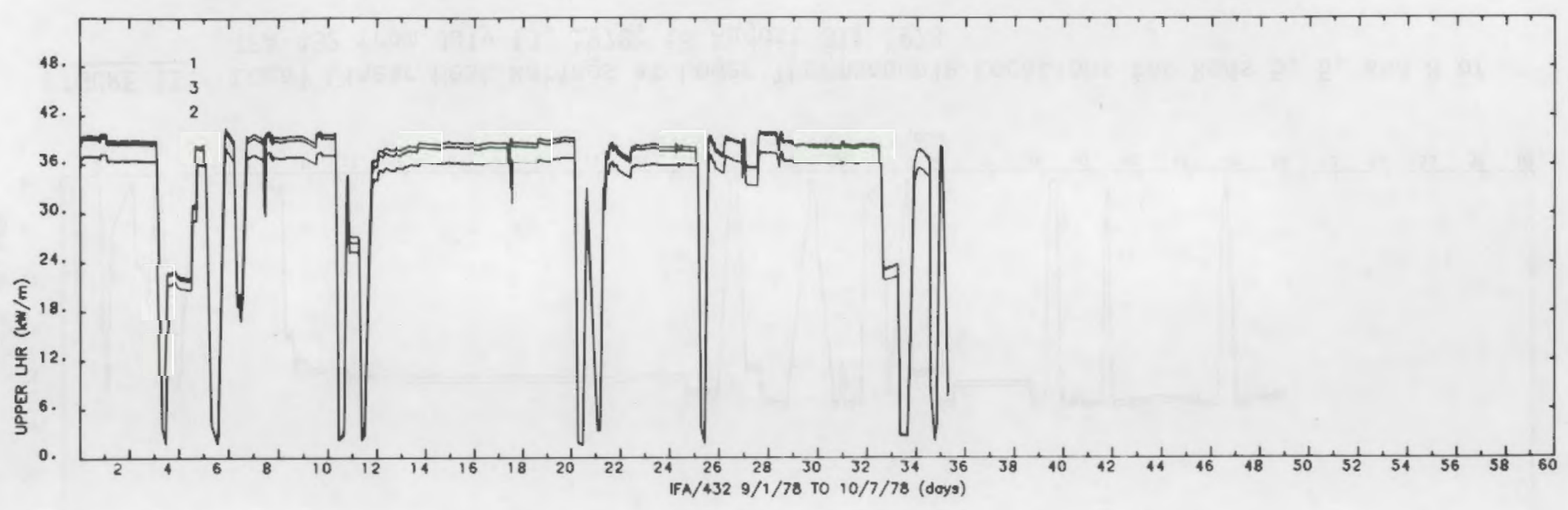

FIGURE 12. Local Linear Heat Ratings at Upper Thermocouple Locations for Rods 1, 2, and 3 of IFA-432 from September 1, 1978, to October 7, 1978

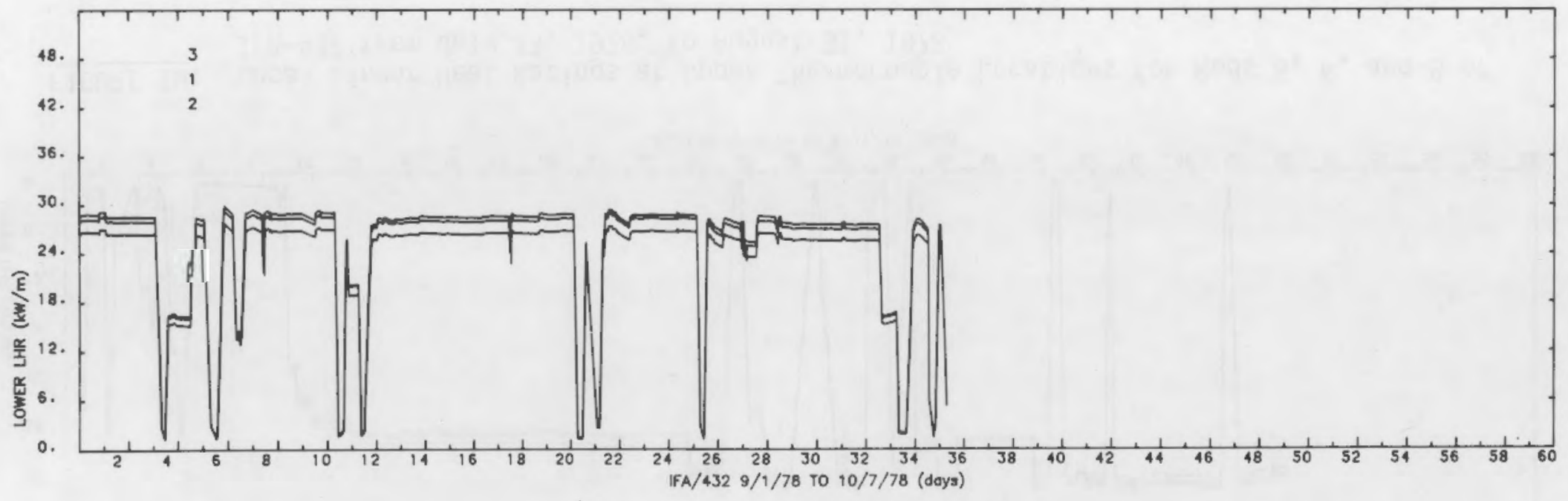

FIGURE 13. Local Linear Heat Ratings at Lower Thermocouple Locations for Rods 1, 2, and 3 of IFA-432 from September 1, 1978, to October 7, 1978 


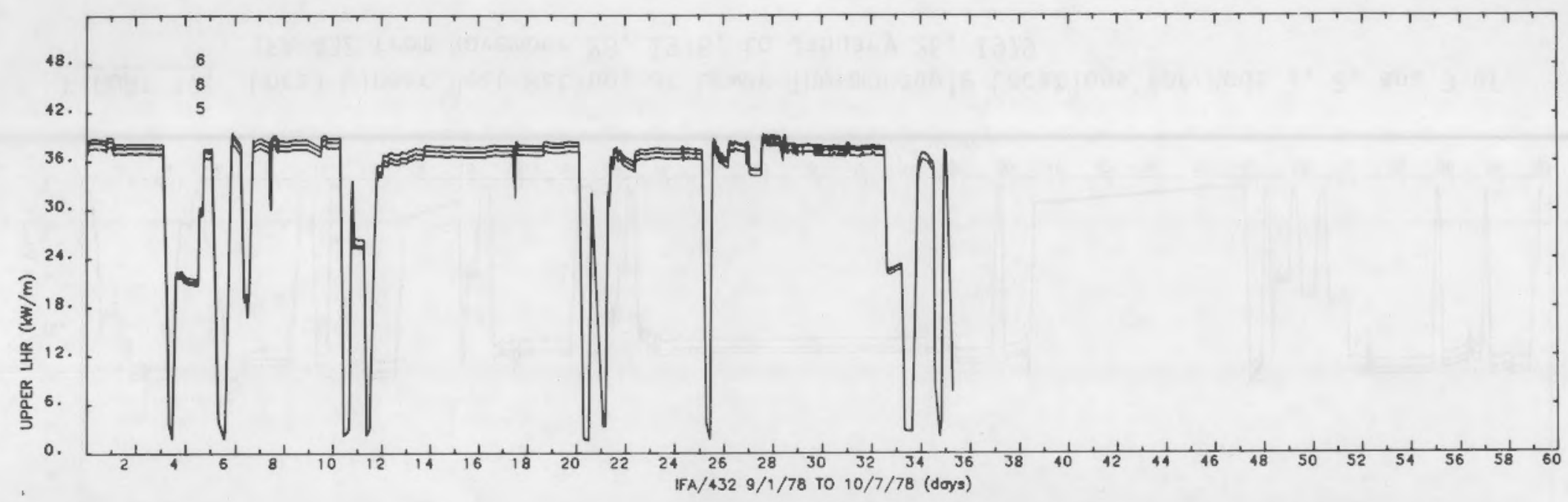

FIGURE 14. Local Linear Heat Ratings at Upper Thermocouple Locations for Rods 5, 6 , and 8 of IFA-432 from September 1, 1978, to October 7, 1978

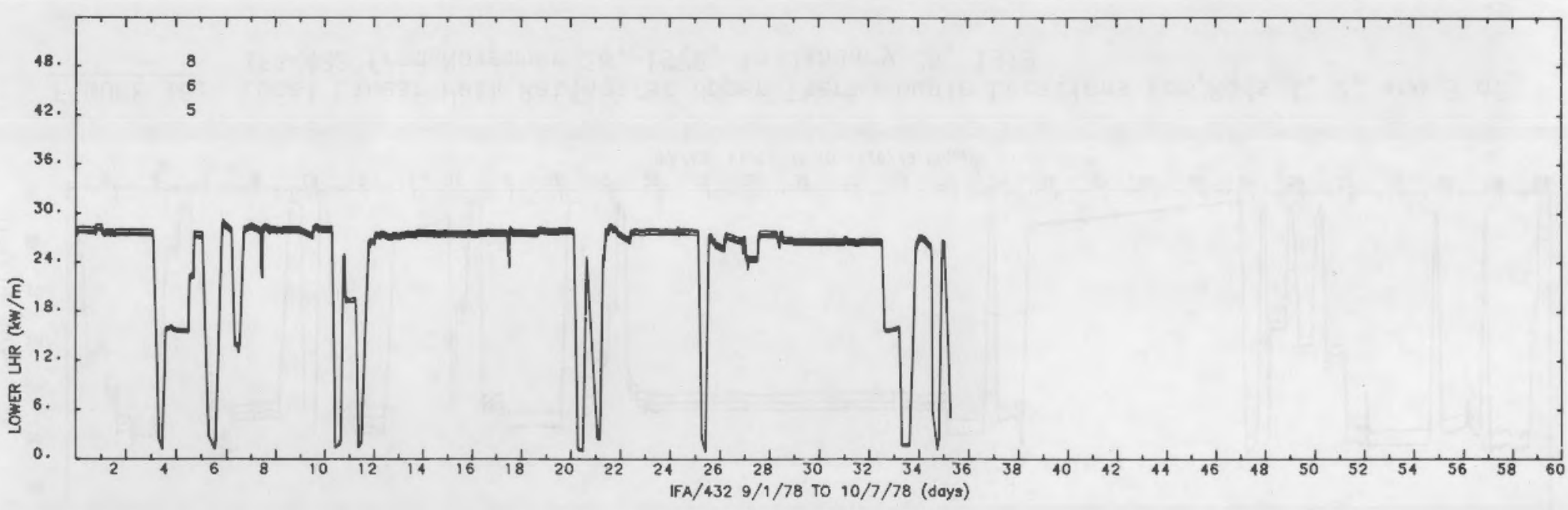

FIGURE 15. Local Linear Heat Ratings at Lower Thermocouple Locations for Rods 5, 6, and 8 of IFA-432 from September 1, 1978, to October 7, 1978 


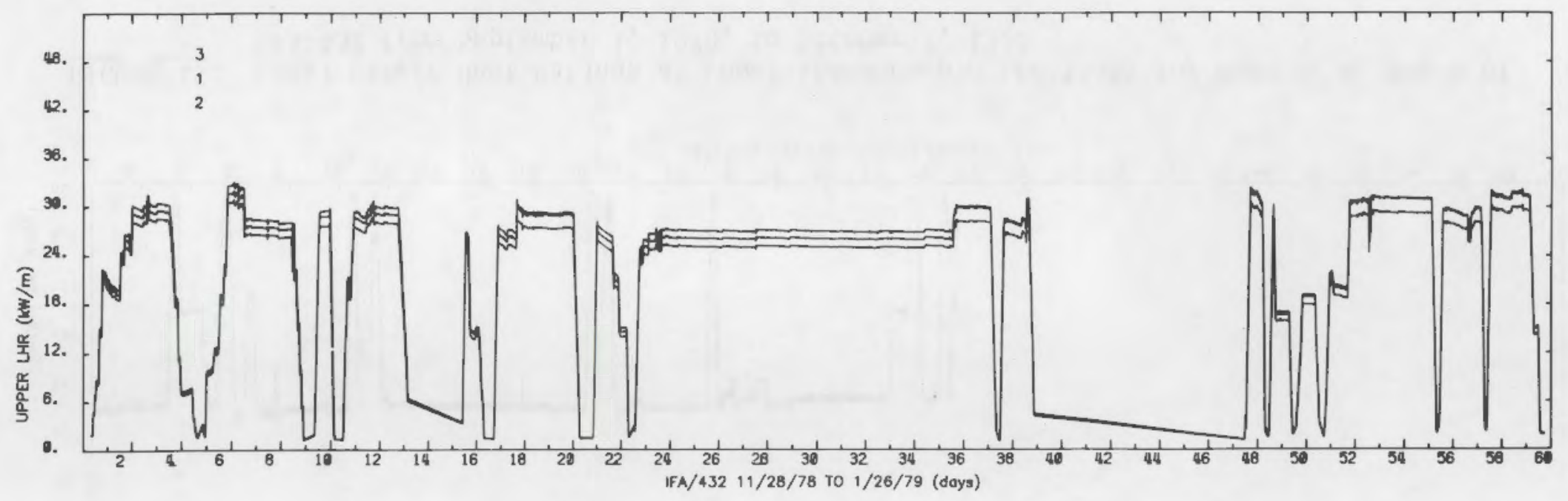

FIGURE 16. Local Linear Heat Ratings at Upper Thermocouple Locations for Rods 1, 2, and 3 of IFA-432 from November 28, 1978, to January 26, 1979

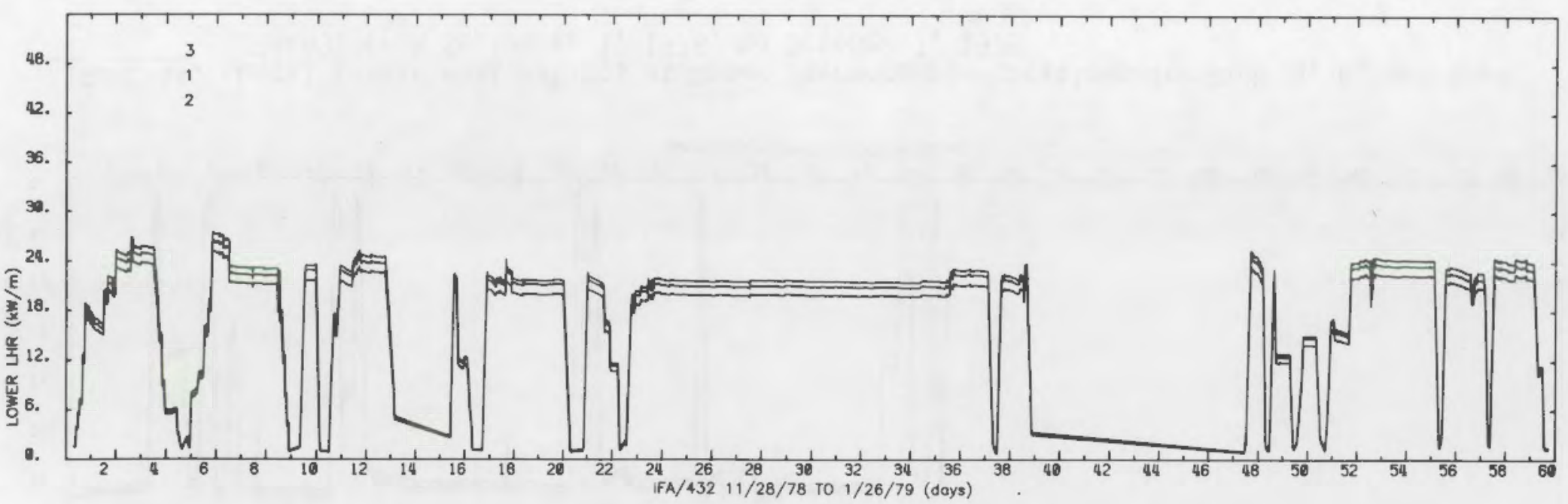

FIGURE 17. Local Linear Heat Ratings at Lower Thermocouple Locations for Rods 1, 2, and 3 of IFA-432 from November 28, 1978, to January 26, 1979 


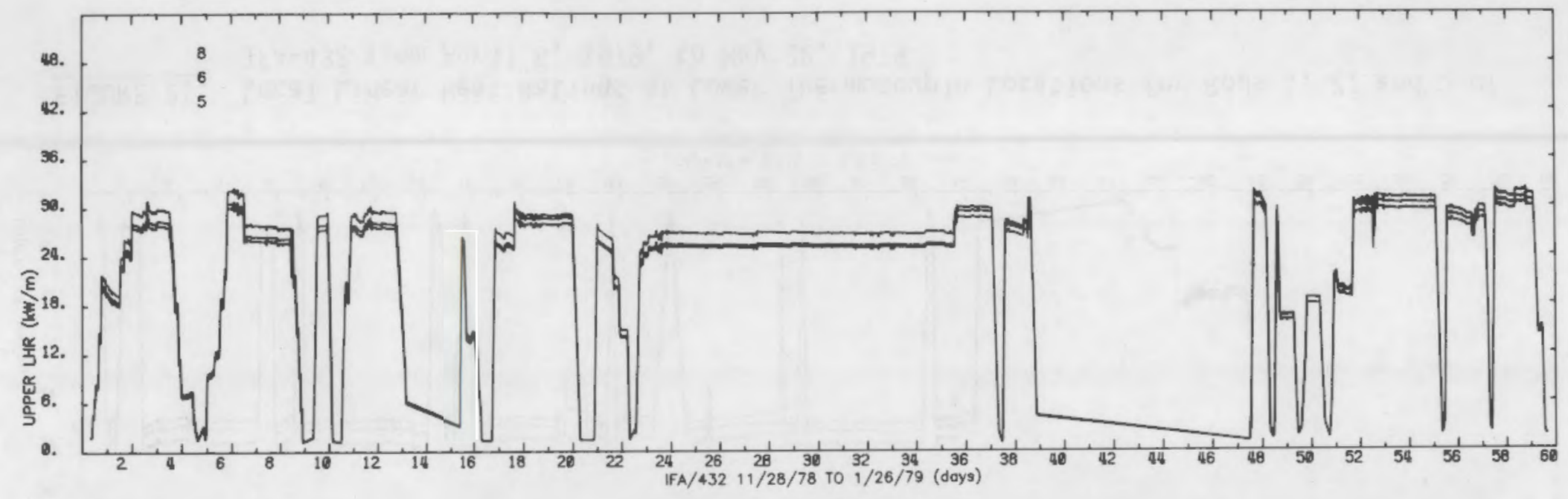

FIGURE 18. Local Linear Heat Ratings at Upper Thermocouple Locations for Rods 5, 6 , and 8 of IFA-432 from November 28, 1978, to January 26, 1979

$\stackrel{N}{\Perp}$

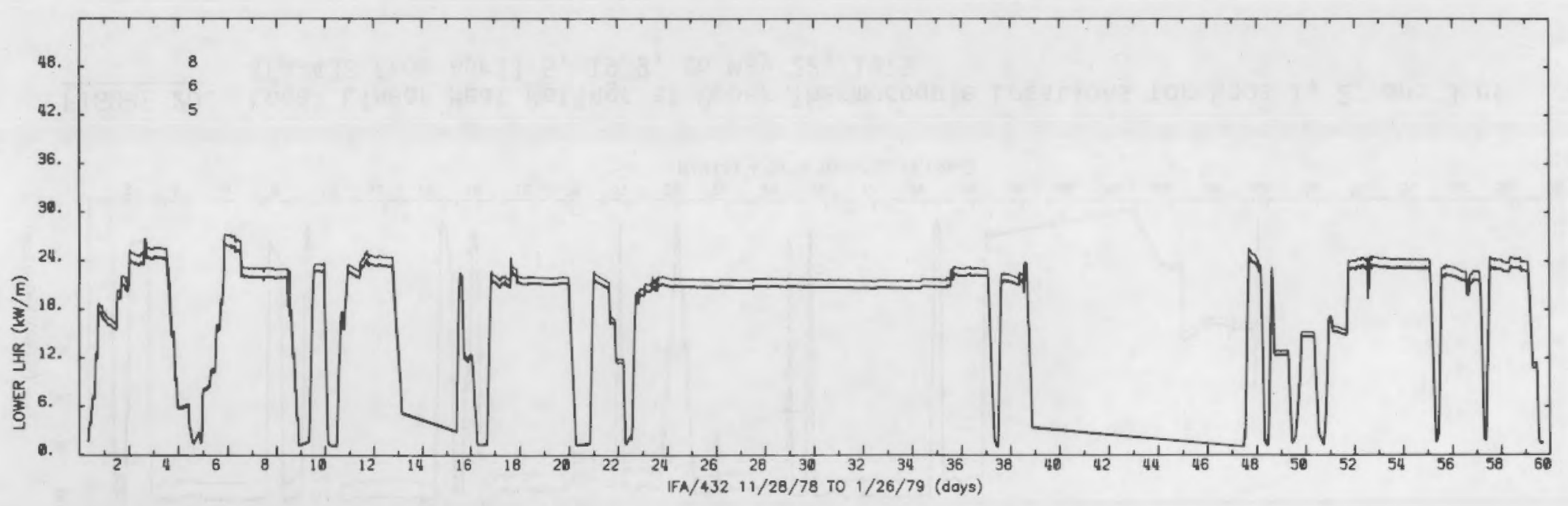

FIGURE 19. Local Linear Heat Ratings at Lower Thermocouple Locations for Rods 5, 6 , and 8 of IFA-432 from November 28, 1978, to January 26, 1979 


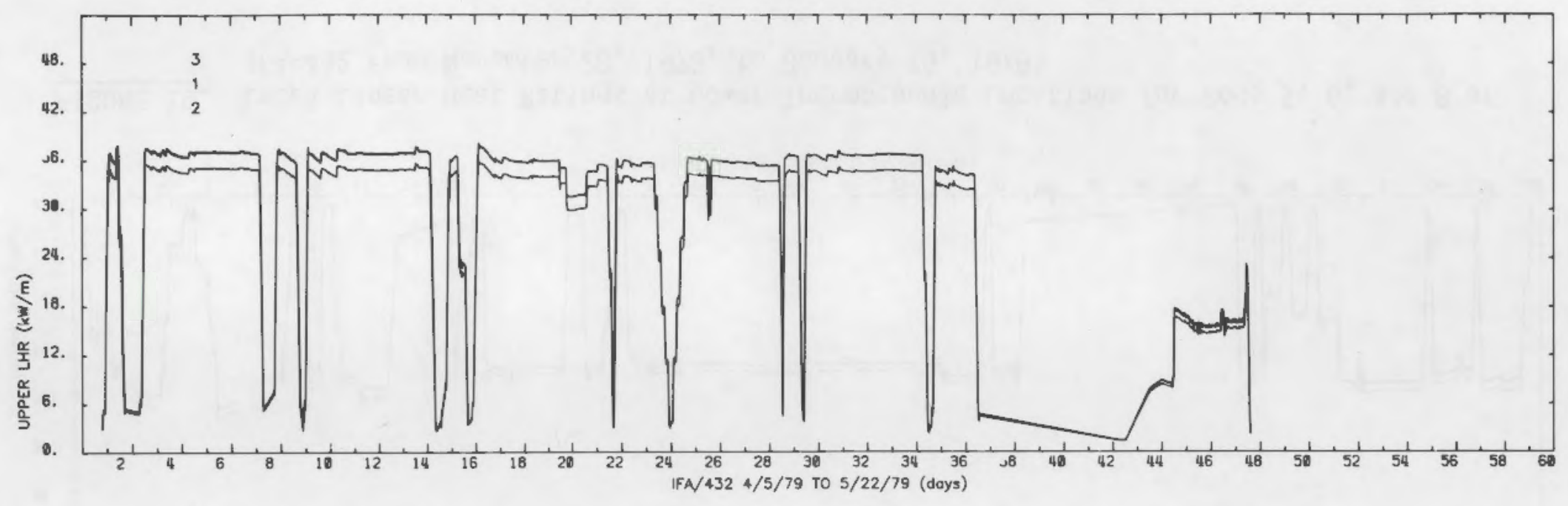

FIGURE 20. Local Linear Heat Ratings at Upper Thermocouple Locations for Rods 1, 2, and 3 of IFA-432 from April 5, 1979, to May 22, 1979

N

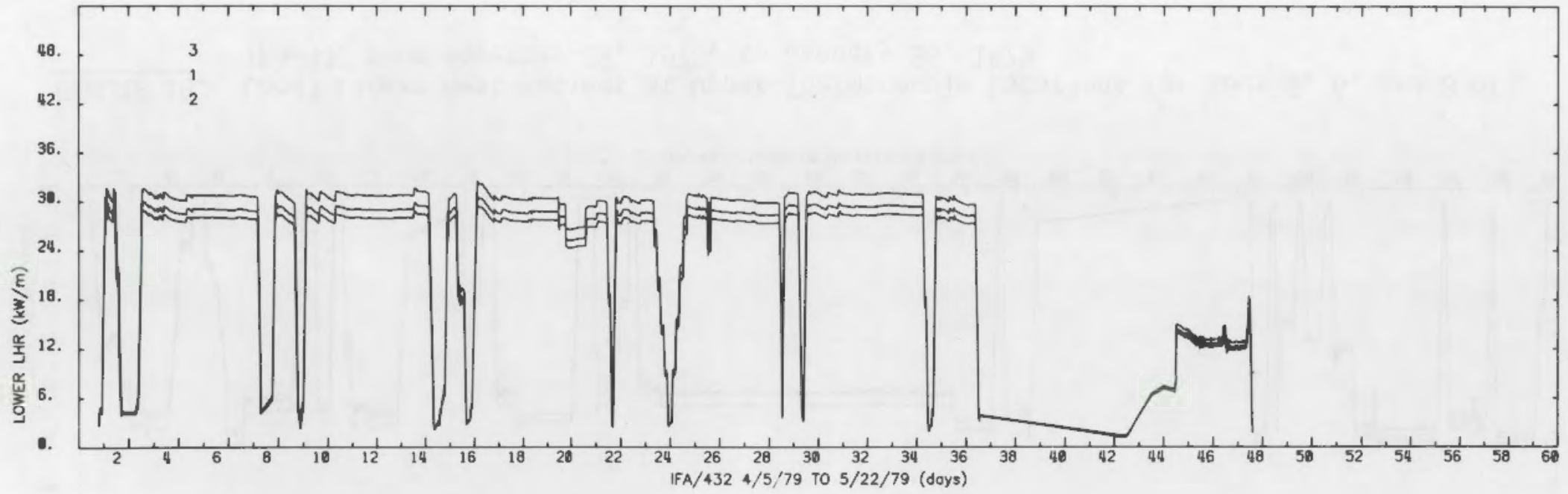

FIGURE 21. Local Linear Heat Ratings at Lower Thermocouple Locations for Rods 1,2, and 3 of IFA-432 from April 5, 1979, to May 22, 1979 


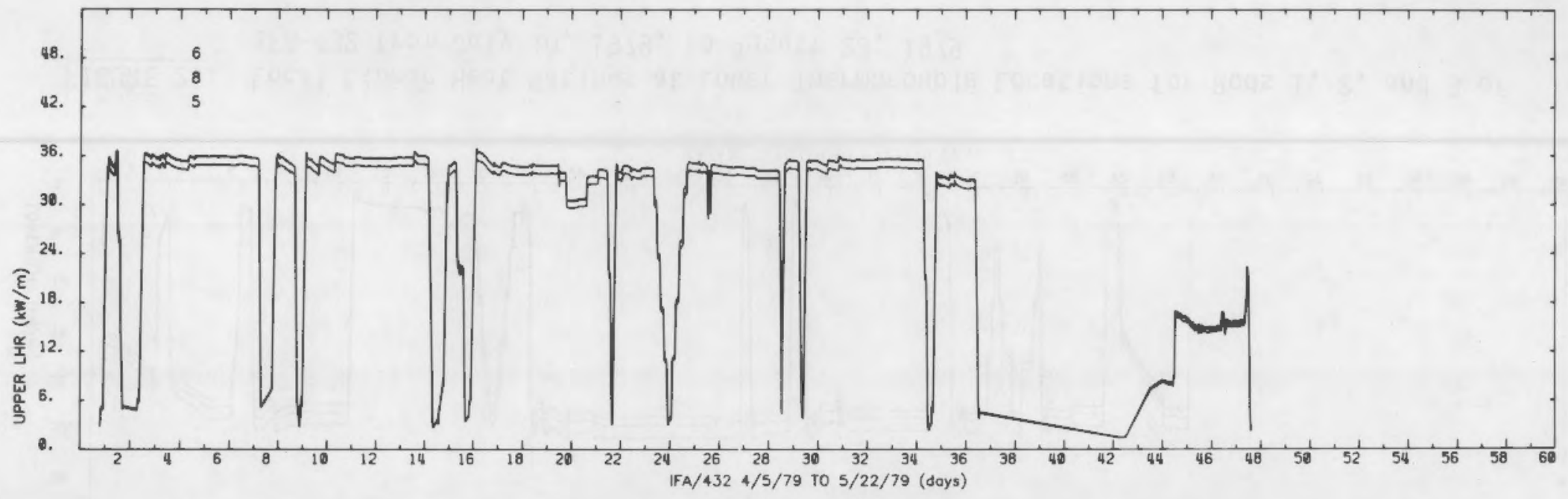

FIGURE 22. Local Linear Heat Ratings at Upper Thermocouple Locations for Rods 5, 6 , and 8 of IFA-432 from April 5, 1979, to May 22, 1979

$\tilde{\omega}$

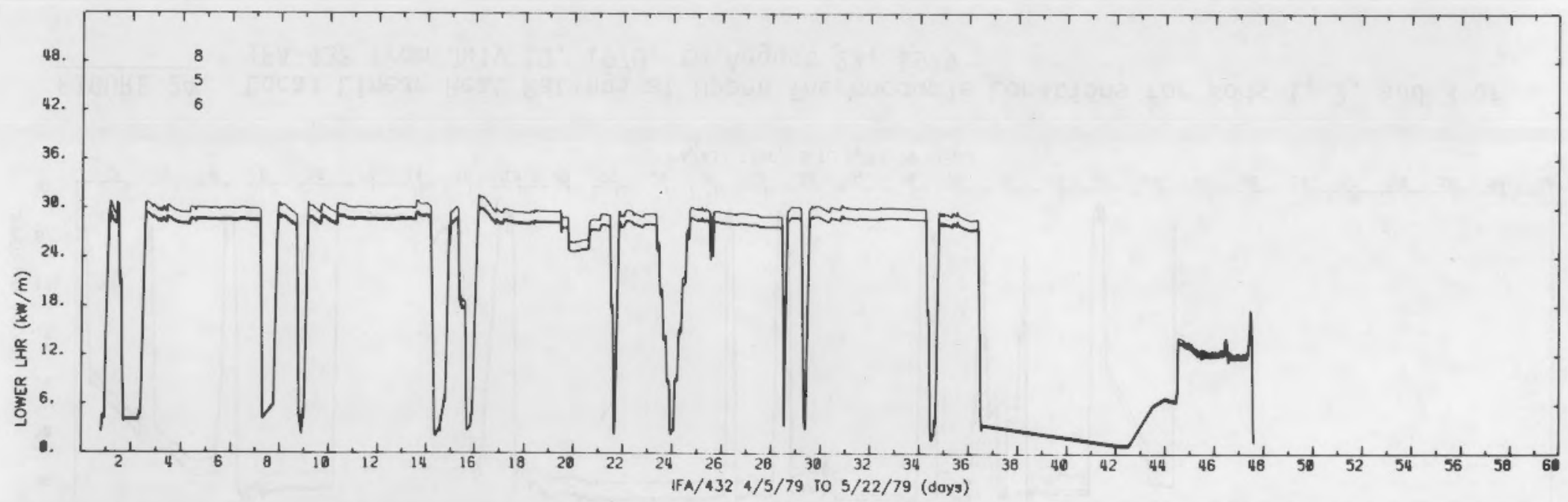

FIGURE 23. Local Linear Heat Ratings at Lower Thermocouple Locations for Rods 5,6 , and 8 of IFA-432 from April 5, 1979, to May 22, 1979 


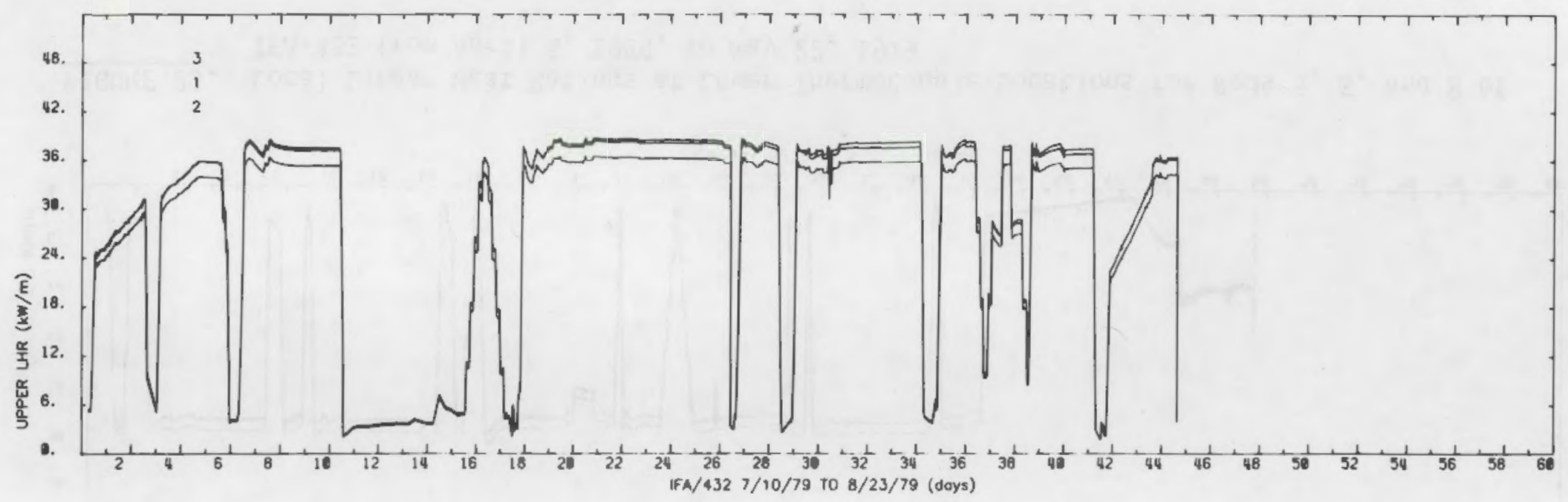

FIGURE 24. Local Linear Heat Ratings at Upper Thermocouple Locations for Rods 1, 2, and 3 of IFA-432 from July 10, 1979, to August 23, 1979

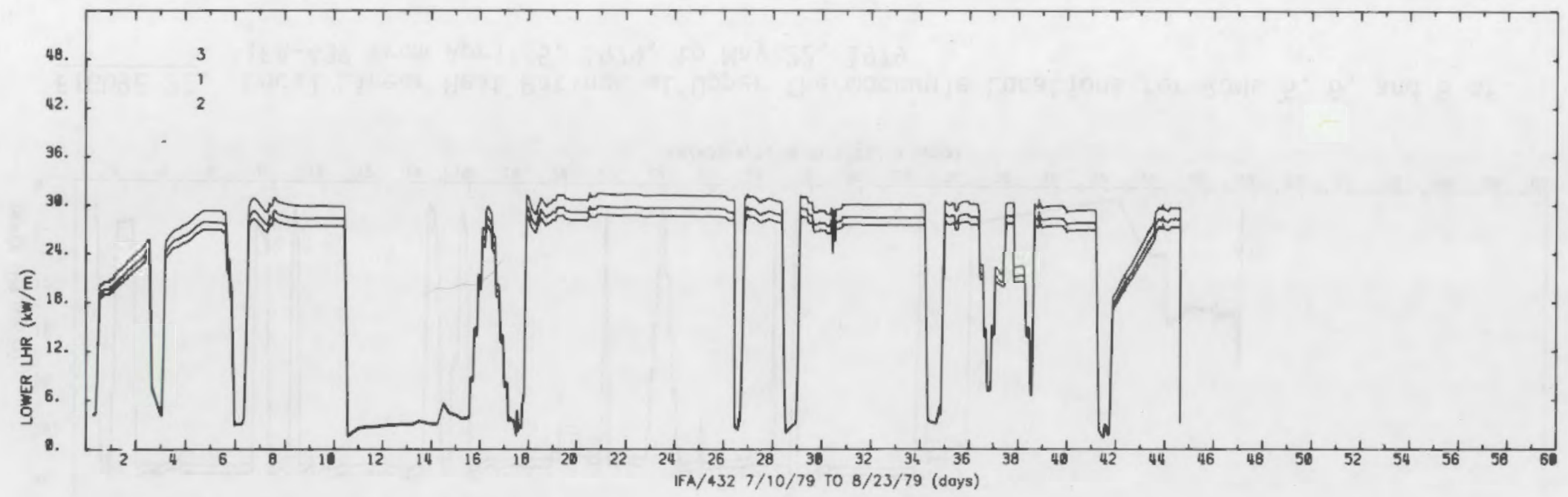

FIGURE 25. Local Linear Heat Ratings at Lower Thermocouple Locations for Rods 1, 2, and 3 of IFA-432 from July 10, 1979, to August 23, 1979 


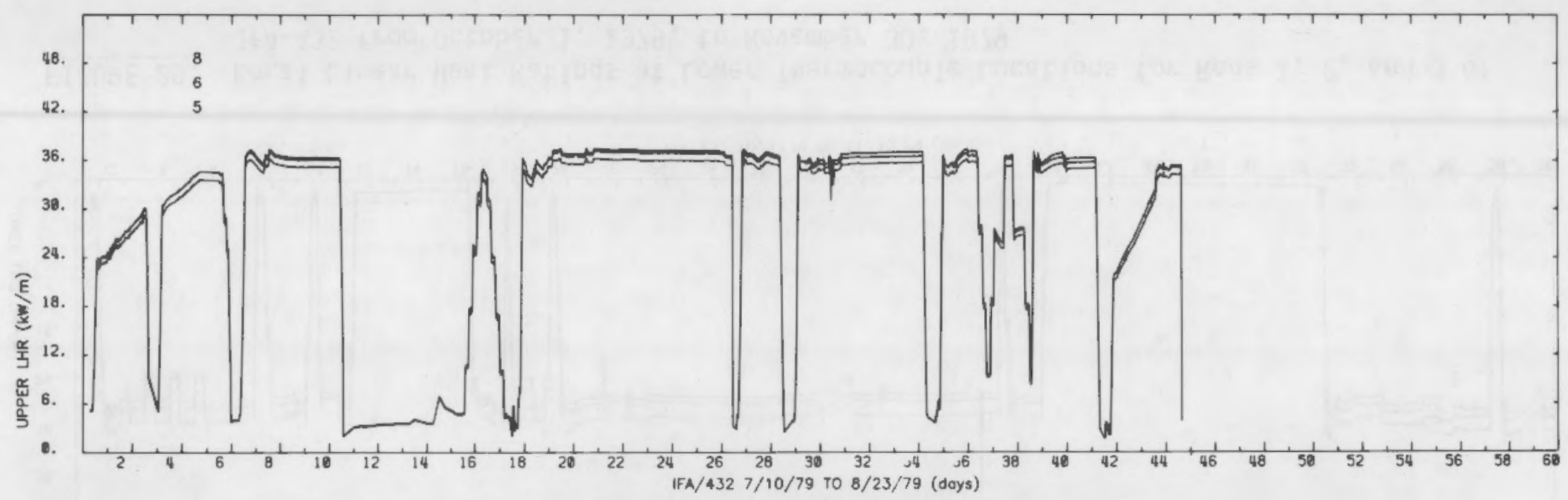

FIGURE 26. Local Linear Heat Ratings at Upper Thermocouple Locations for Rods 5, 6, and 8 of IFA-432 from July 10, 1979, to August 23, 1979

G

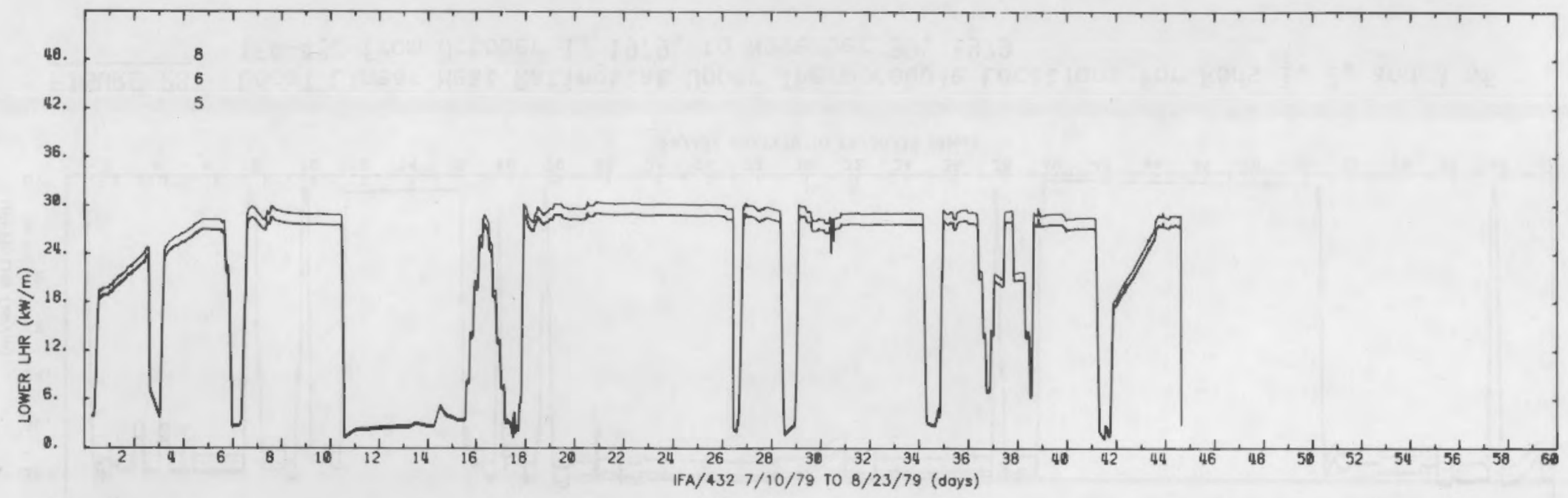

FIGURE 27. Local Linear Heat Ratings at Lower Thermocouple Locations for Rods 5, 6 , and 8 of IFA-432 from July 10, 1979, to August 23, 1979 


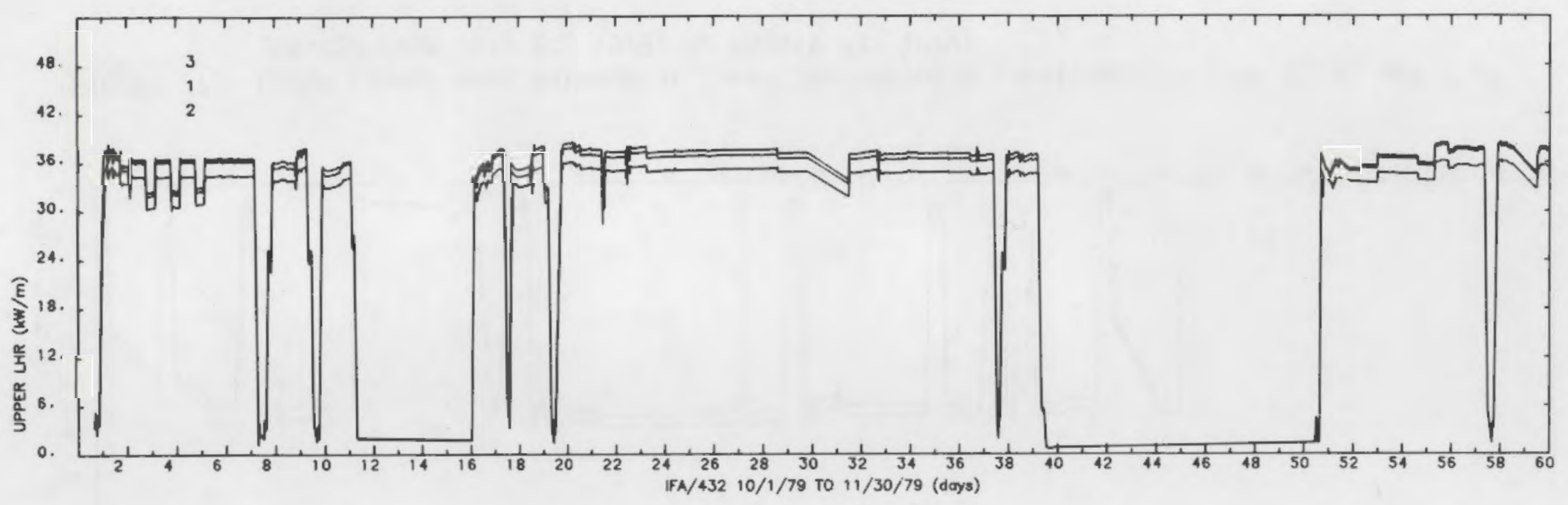

FIGURE 28. Local Linear Heat Ratings at Upper Thermocouple Locations for Rods 1,2 , and 3 of IFA-432 from October 1, 1979, to November 30, 1979

๙

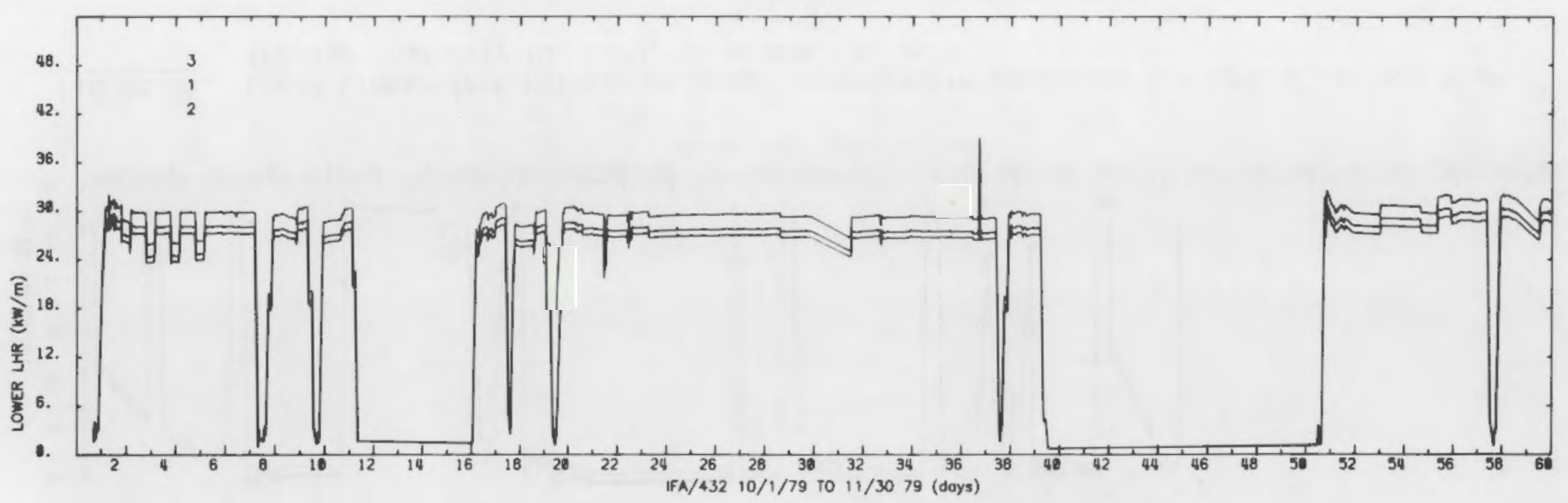

FIGURE 29. Local Linear Heat Ratings at Lower Thermocouple Locations for Rods 1, 2, and 3 of IFA-432 from October 1, 1979, to November 30, 1979 


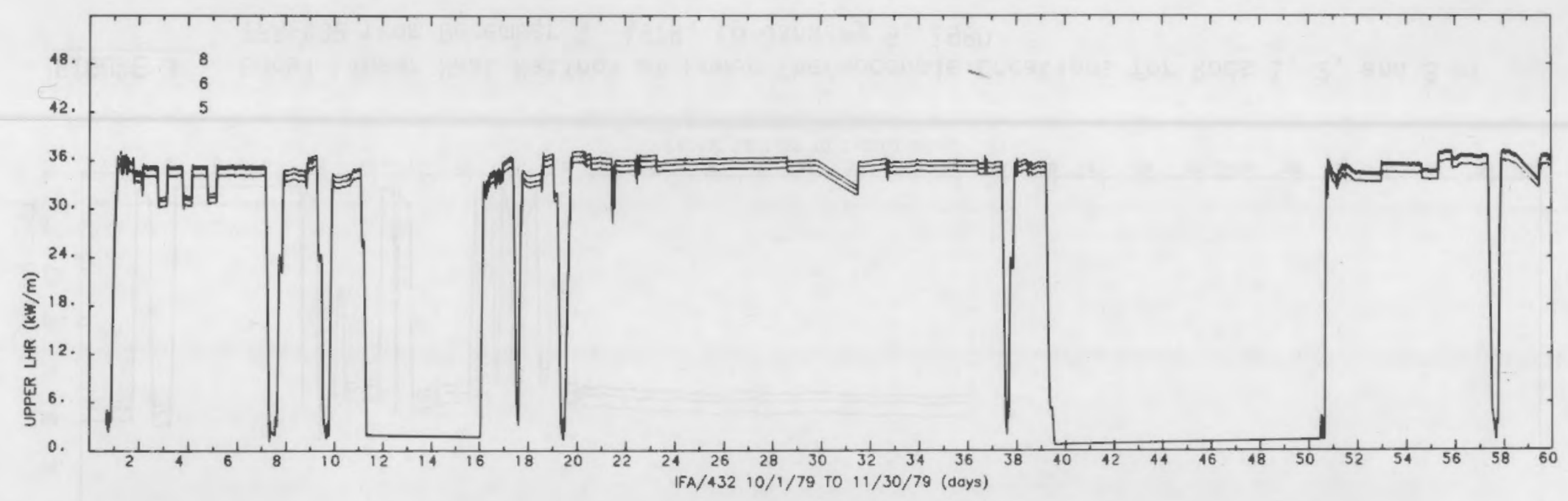

FIGURE 30. Local Linear Heat Ratings at Upper Thermocouple Locations for Rods 5, 6, and 8 of IFA-432 from October 1, 1979, to November 30, 1979

$\mathfrak{n}$

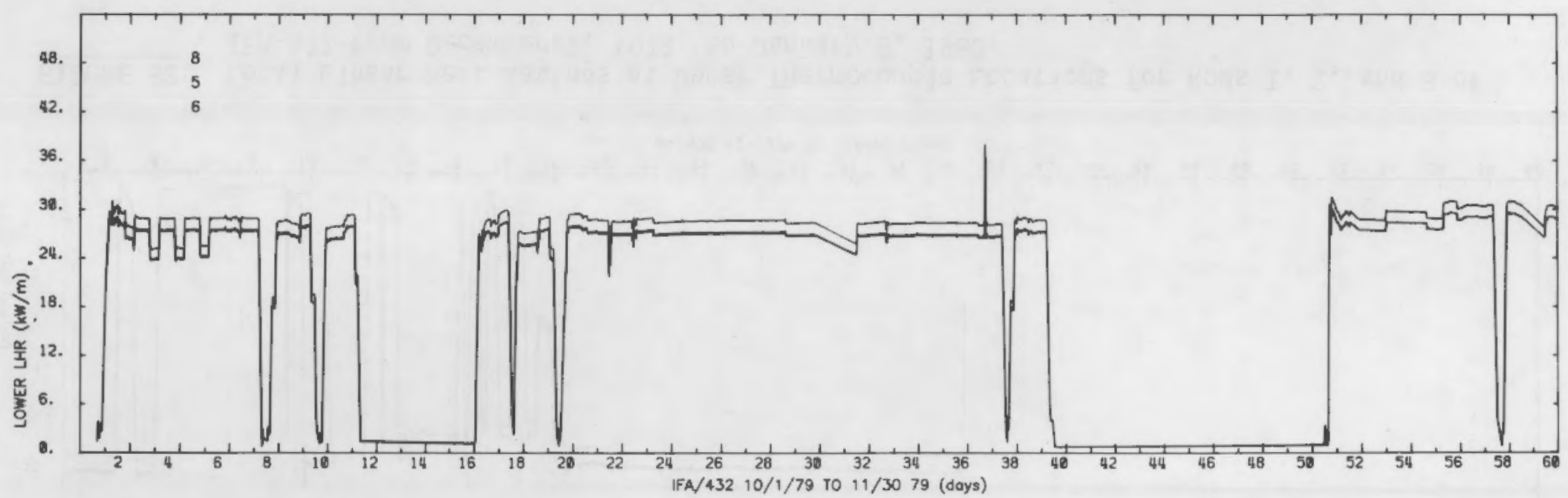

FIGURE 31. Local Linear Heat Ratings at Lower Thermocouple Locations for Rods 5, 6, and 8 of IFA-432 from October 1, 1979, to November 30, 1979 


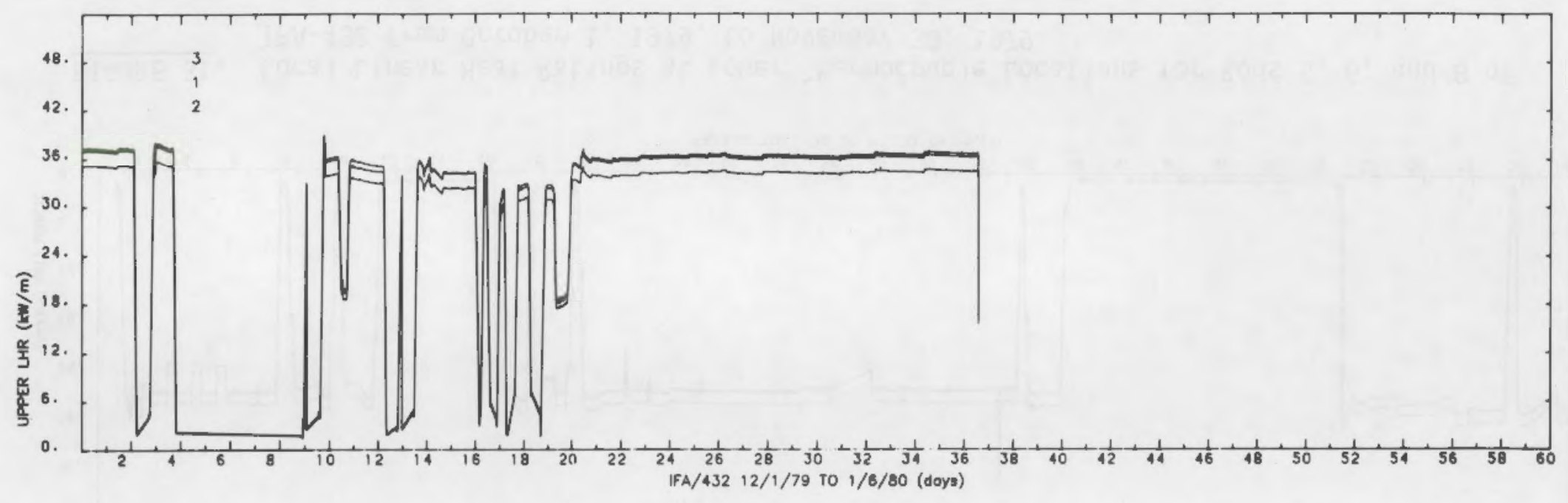

FIGURE 32. Local Linear Heat Ratings at Upper Thermocouple Locations for Rods 1, 2, and 3 of IFA-432 from December 1, 1979, to January 6, 1980

๓

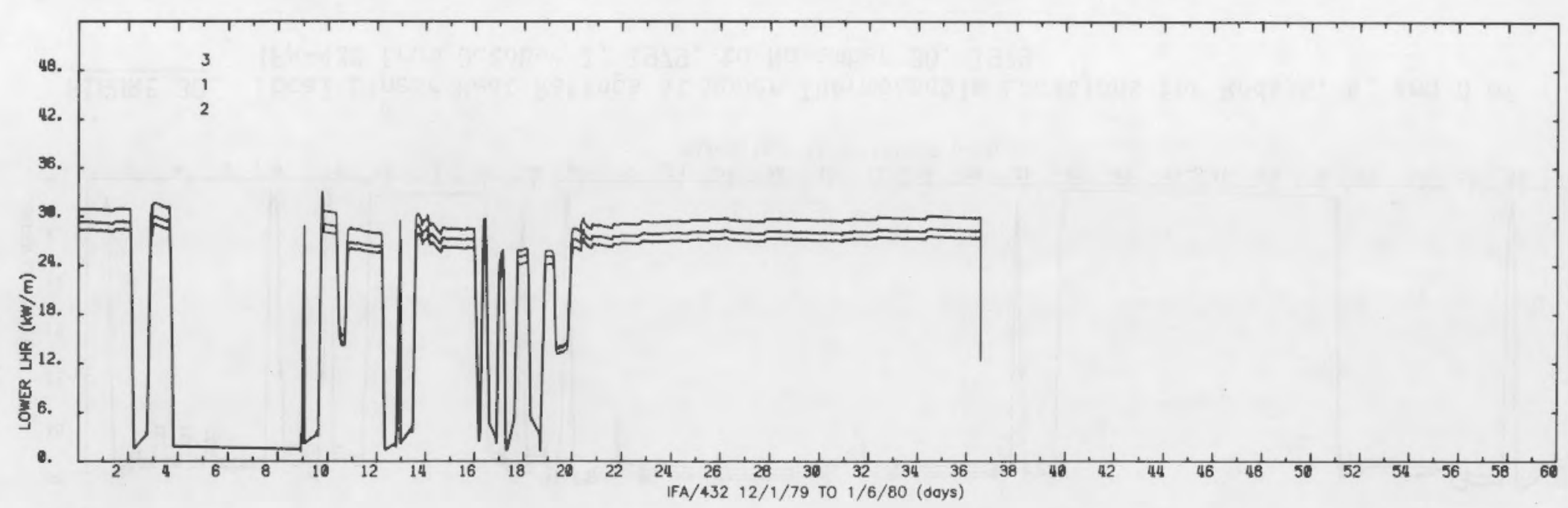

FIGURE 33. Local Linear Heat Ratings at Lower Thermocouple Locations for Rods 1, 2, and 3 of IFA-432 from December 1, 1979, to January 6, 1980 


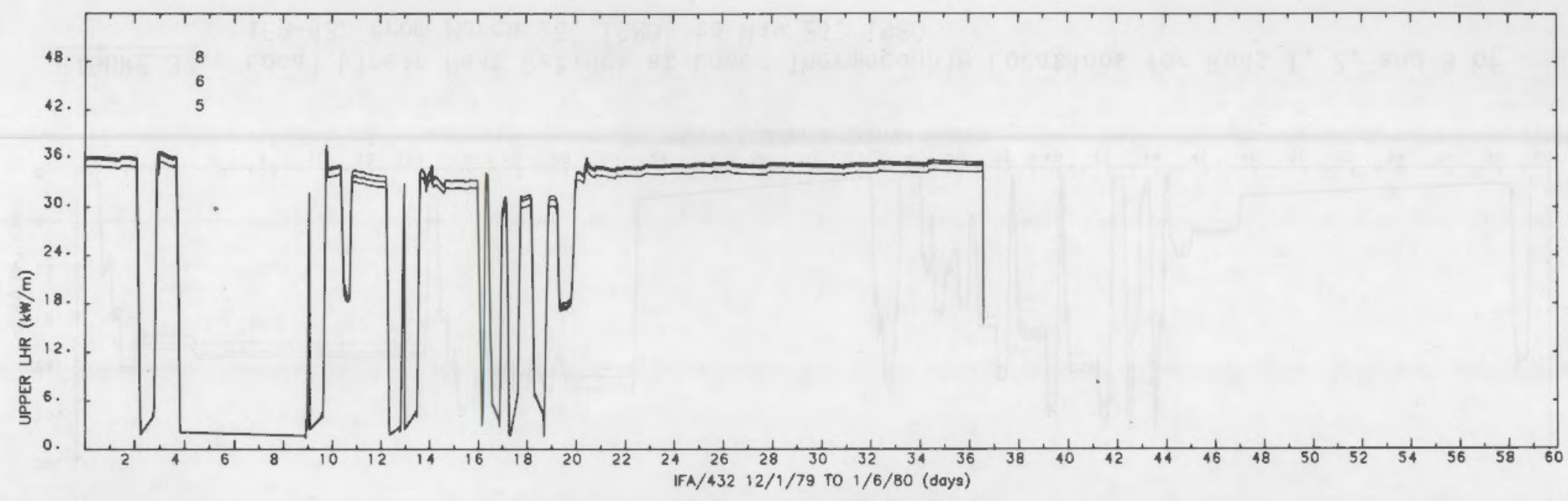

FIGURE 34. Local Linear Heat Ratings at Upper Thermocouple Locations for Rods 5, 6, and 8 of IFA-432 from December 1, 1979, to January 6, 1980

กั้

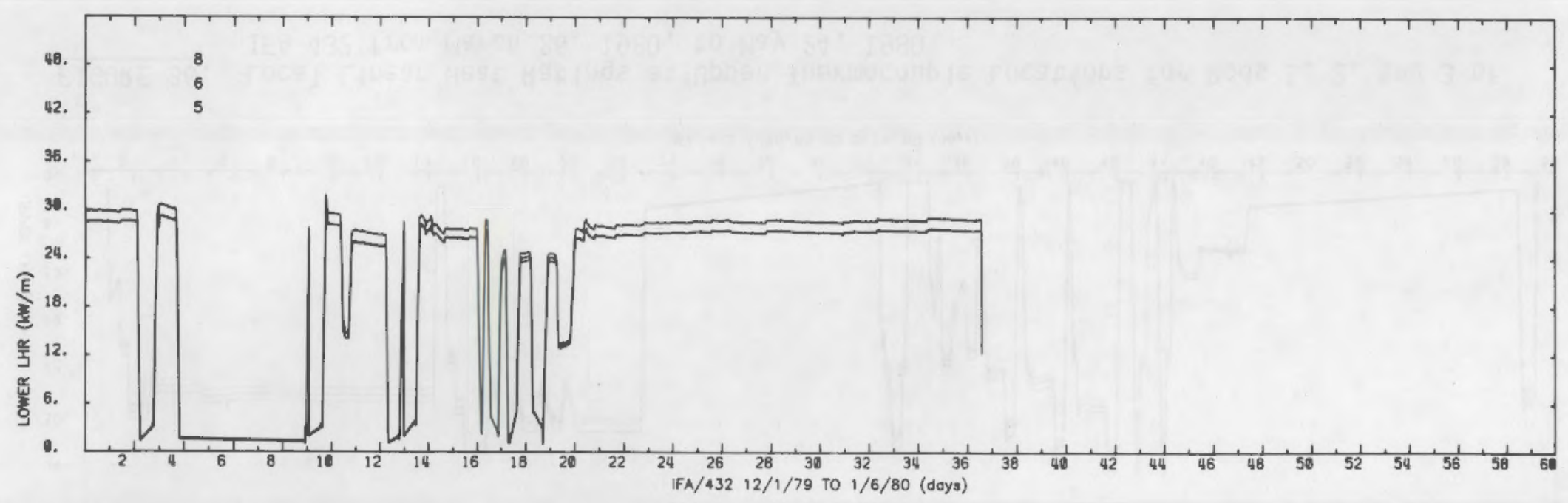

FIGURE 35. Local Linear Heat Ratings at Lower Thermocouple Locations for Rods 5, 6, and 8 of IFA-432 from December 1, 1979, to January 6, 1980 


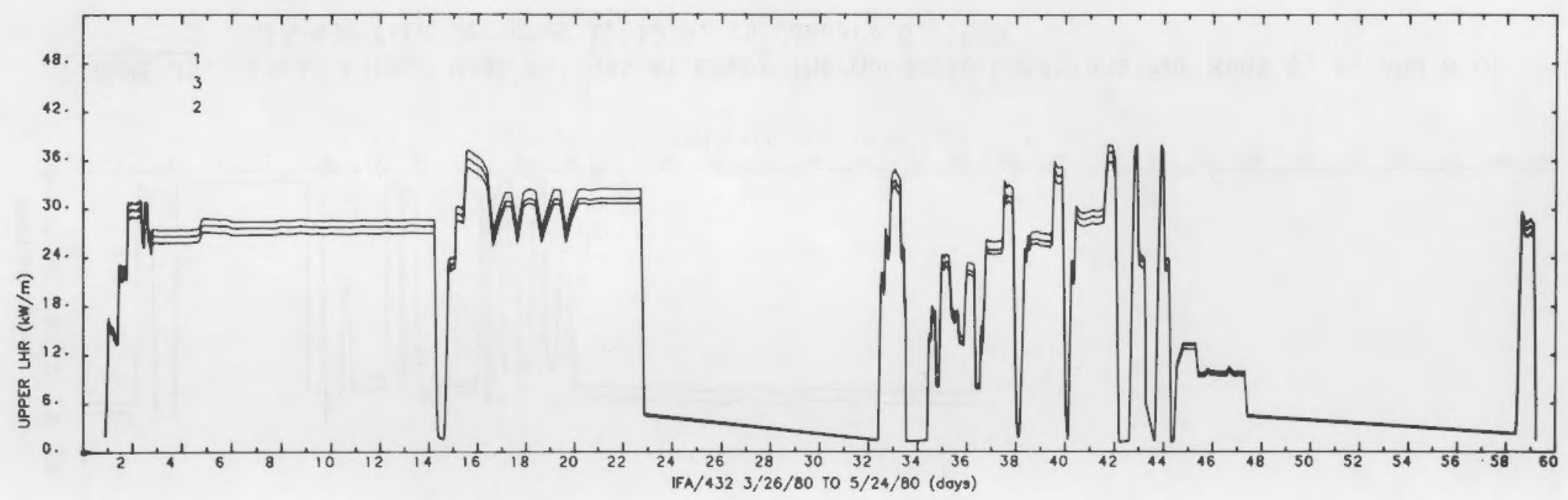

FIGURE 36. Local Linear Heat Ratings at Upper Thermocouple Locations for Rods 1, 2, and 3 of IFA-432 from March 26, 1980 , to May 24, 1980

$\ddot{o}$

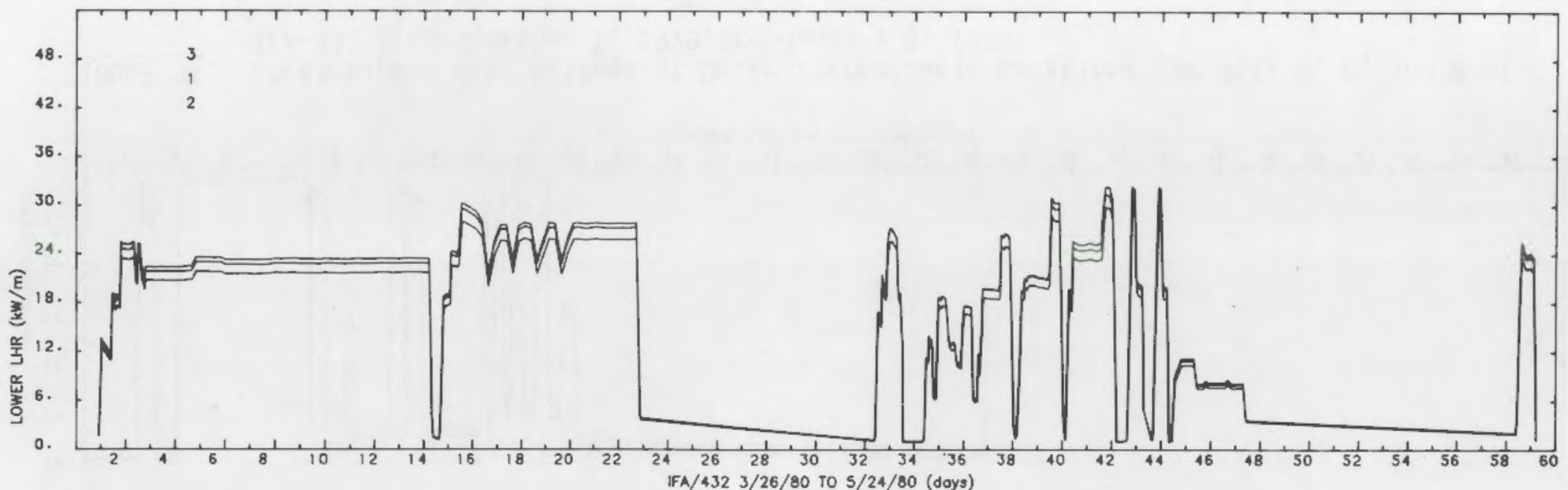

FIGURE 37. Local Linear Heat Ratings at Lower Thermocouple Locations for Rods 1, 2, and 3 of IFA-432 from March 26, 1980, to May 24, 1980 


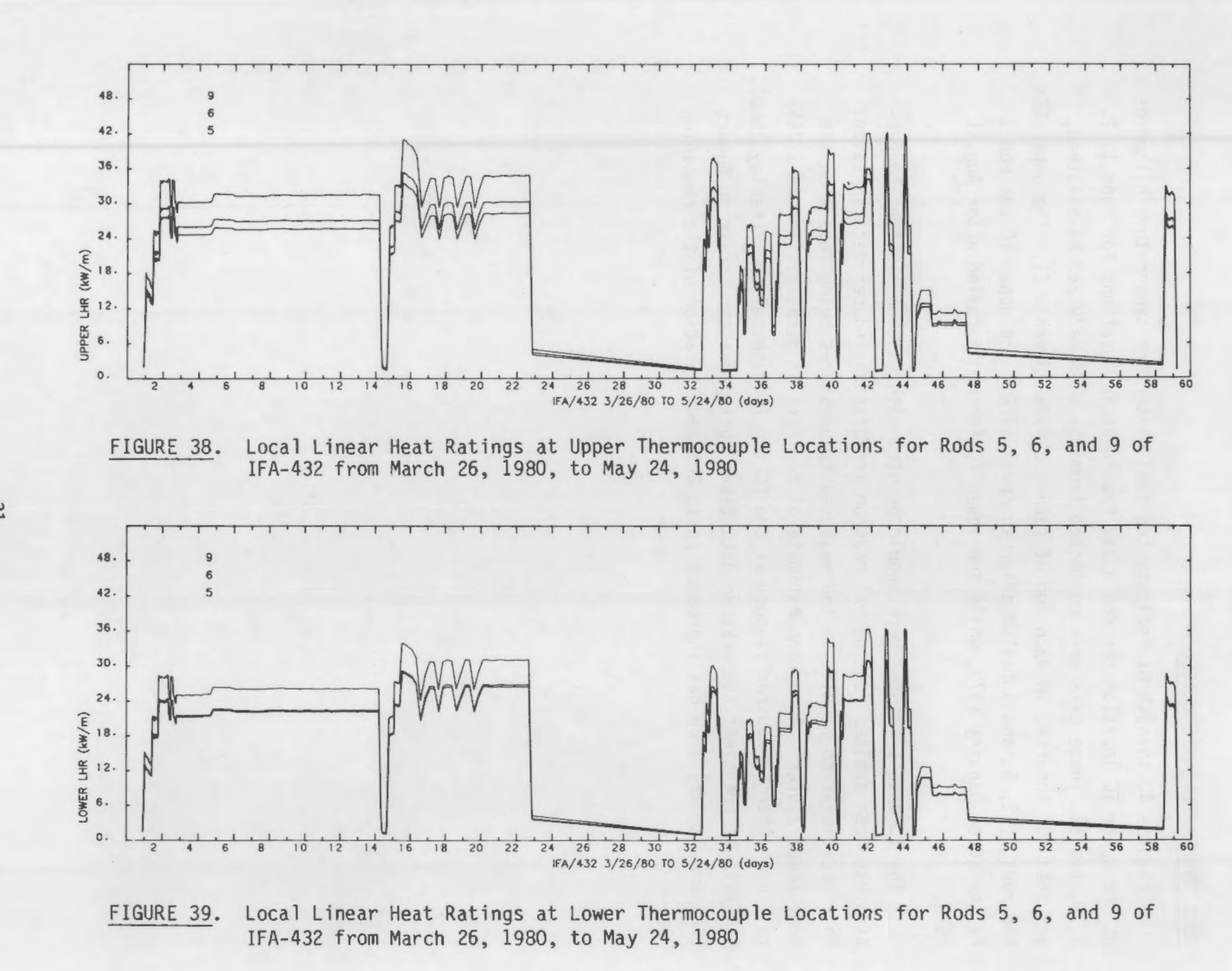




\section{FUEL TEMPERATURE HISTORIES}

Figures 40 through 61 indicate the fue 1 centerline temperature histories at the upper TC location for rod 3 and the lower TC locations for rods 1, 2, 3,5 , and 6 . These data were collected from the $W 5 \% \operatorname{Re} / W 26 \%$ Re-sheathed, grounded TCs inserted in each end of each rod (see Appendix C). The upper TCs for rods 1, 2, 5, and 6 failed prior to April 1978. The upper TC for rod 3 failed after January 1979, while the lower TC for rod 6 failed after August 1979.

The TC data presented here should be used with caution since no correction has been applied for thermal neutron irradiation-induced decalibration. This decalibration results in the measured temperatures being less than the true temperatures. A current estimate of the rate of decalibration is $1.75 \%$ / $10^{24} \mathrm{n} / \mathrm{m}^{2}$ thermal neutron fluence at the TC tip (Crouthamel and Freshley 1980). Analysis of transient temperature data taken during reactor scrams in August 1979 and January 1980 has indicated up to $20 \%$ decalibration of the remaining TCs. 


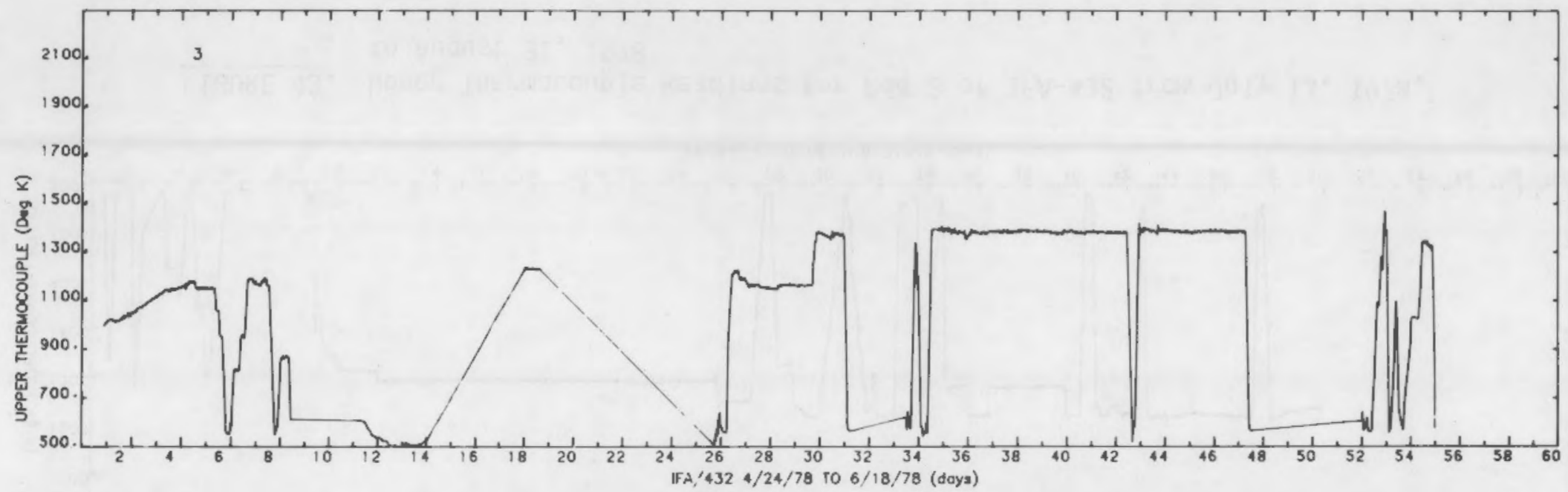

FIGURE 40. Upper Thermocouple Readings for Rod 3 of IFA-432 from April 24, 1978, to June 18,1978

$\omega$

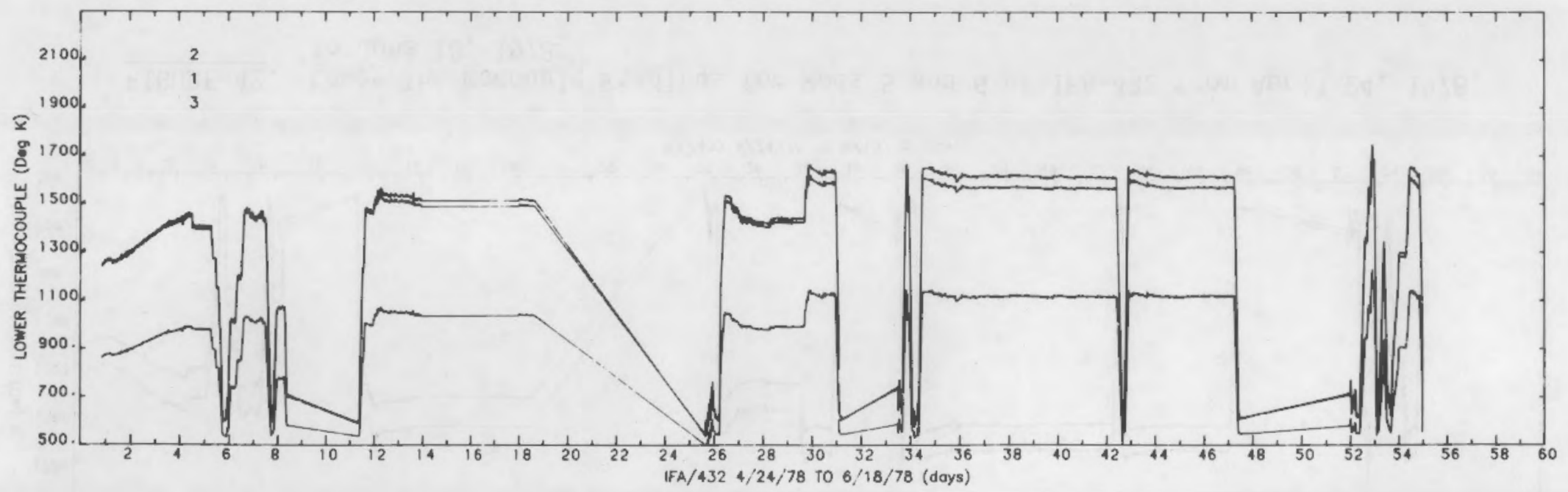

FIGURE 41. Lower Thermocouple Readings for Rods 1, 2, and 3 of IFA-432 from April 24, 1978, to June 18, 1978 


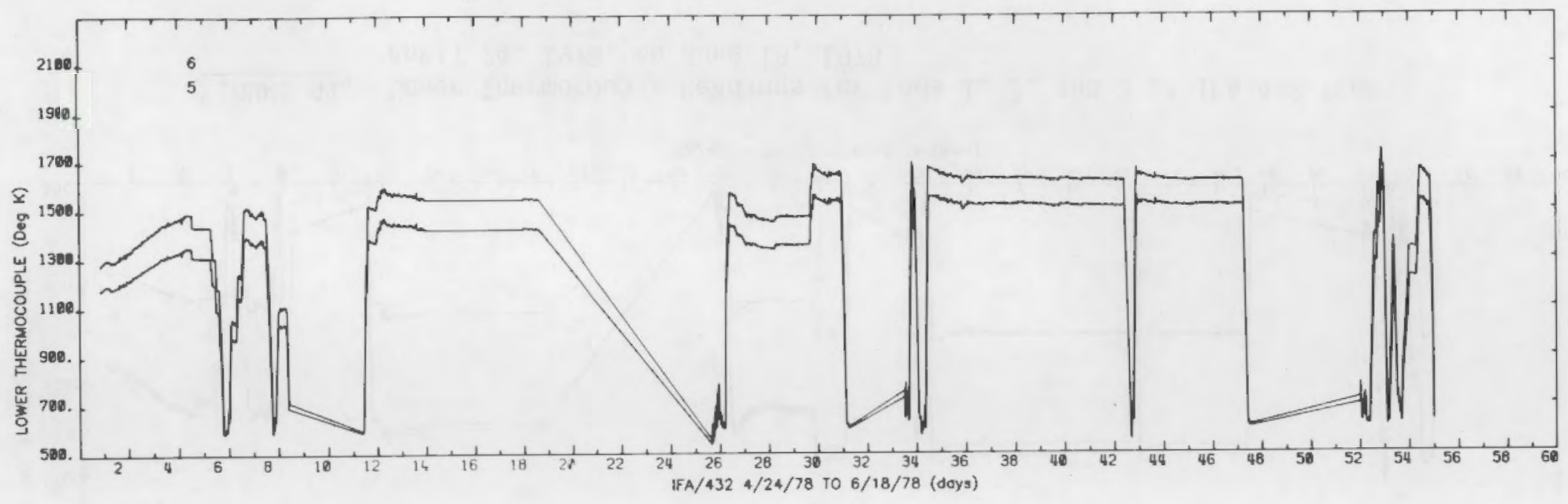

FIGURE 42. Lower Thermocouple Readings for Rods 5 and 6 of IFA-432 from April 24, 1978, to June 18,1978

$\stackrel{\omega}{\perp}$

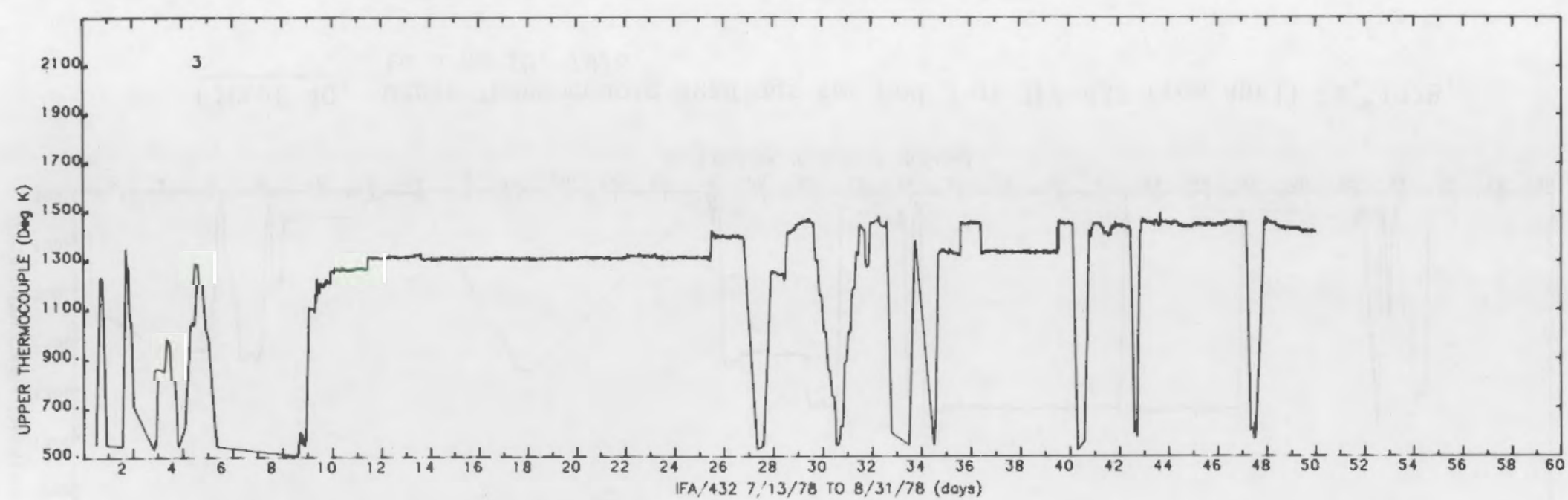

FIGURE 43. Upper Thermocouple Readings for Rod 3 of IFA-432 from July 13, 1978, to August 31,1978 


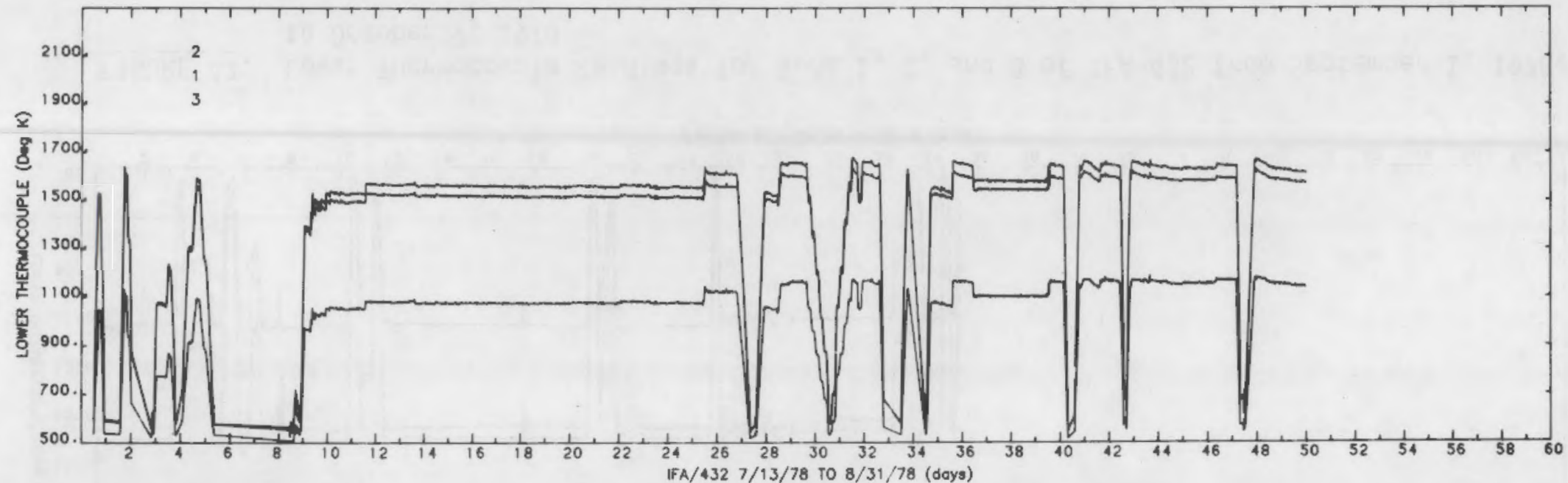

FIGURE 44. Lower Thermocouple Readings for Rods 1, 2, and 3 of IFA-432 from July 13, 1978, to August 31, 1978

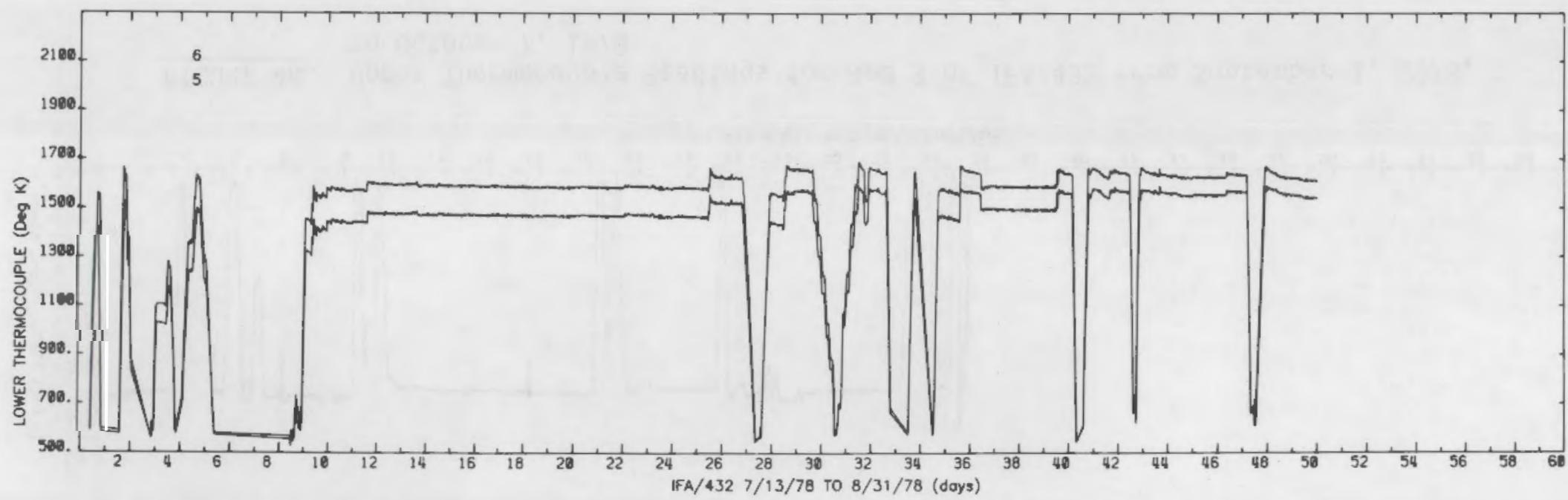

FIGURE 45. Lower Thermocouple Readings for Rods 5 and 6 of IFA-432 from July 13, 1978, to August 31, 1978 


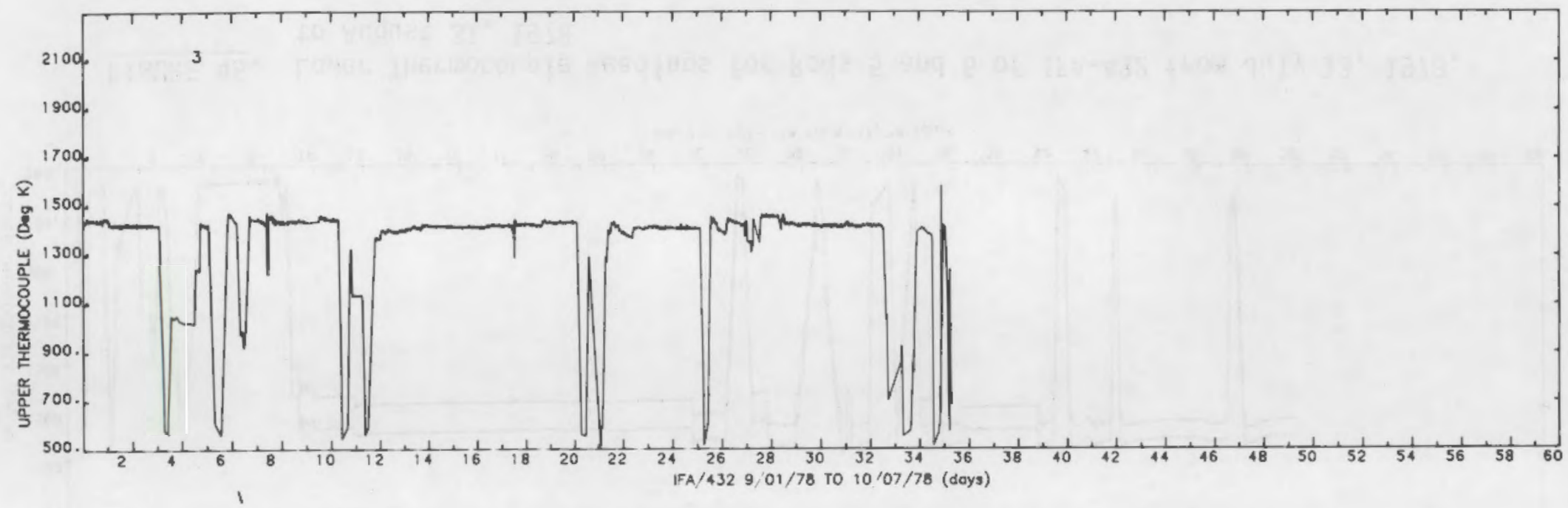

FIGURE 46. Upper Thermocouple Readings for Rod 3 of IFA-432 from September 1, 1978, w

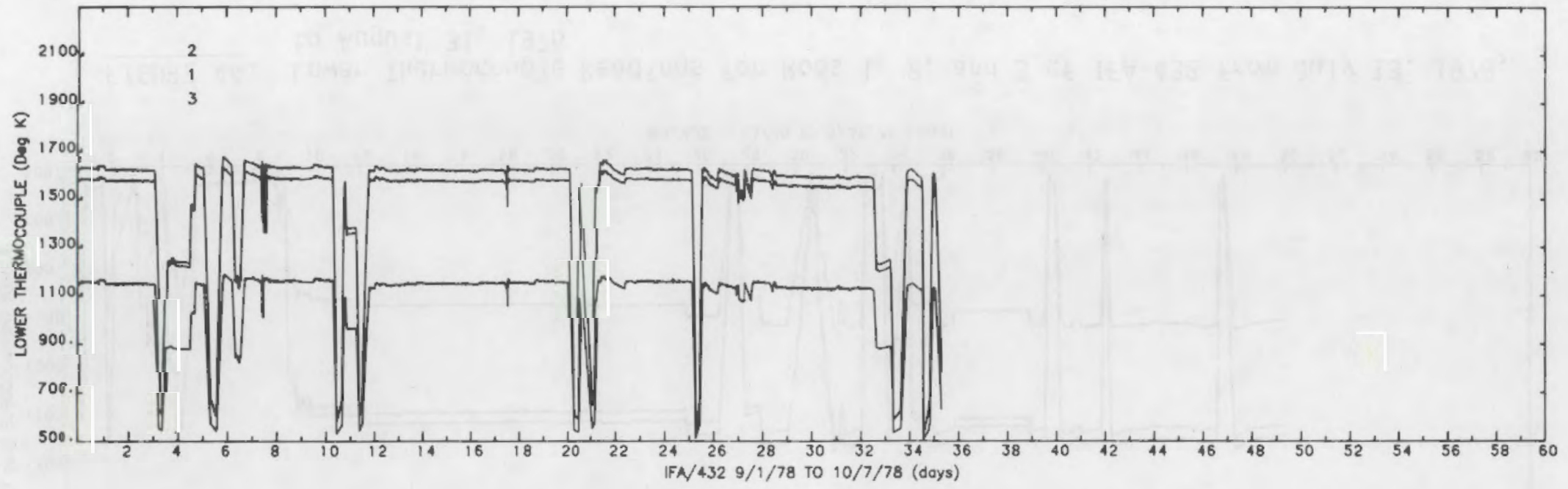

FIGURE 47. Lower Thermocouple Readings for Rods 1, 2, and 3 of IFA-432 from September 1, 1978, to October 7, 1978 


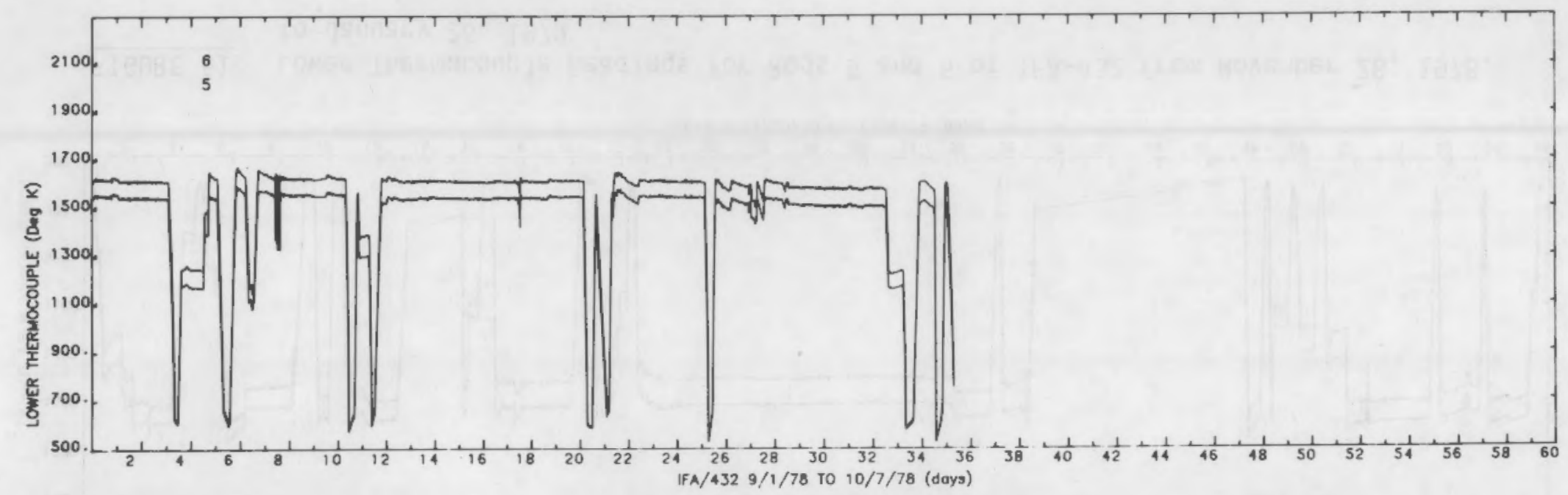

FIGURE 48. Lower Thermocouple Readings for Rods 5 and 6 of IFA-432 from September 1, 1978, to October 7, 1978

w

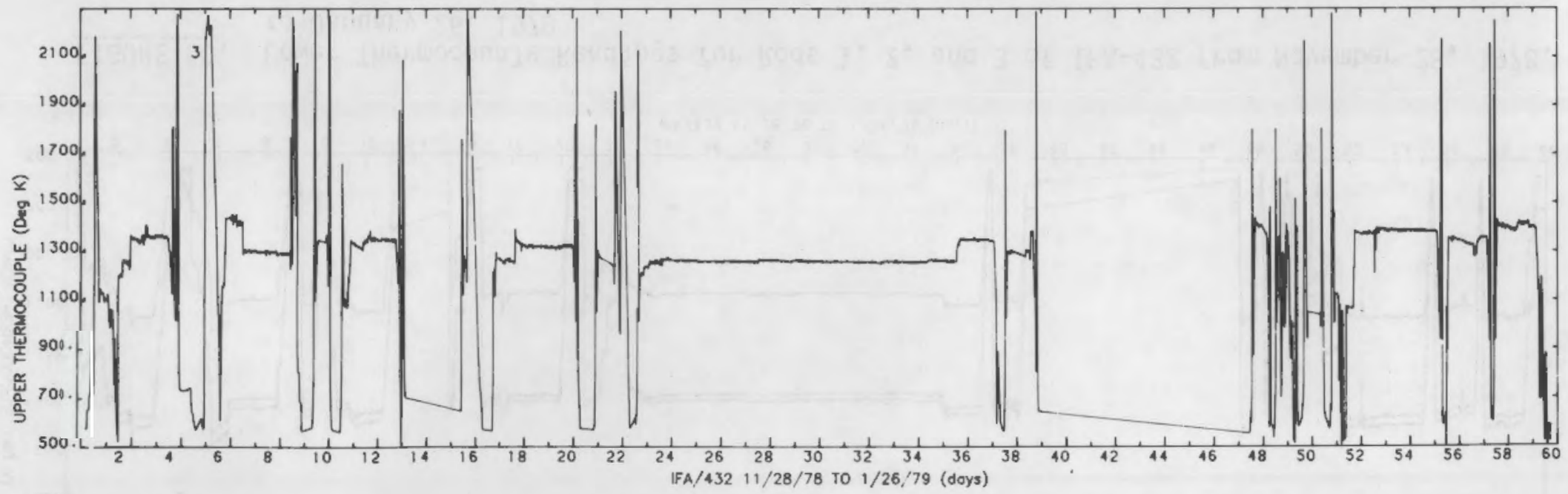

FIGURE 49. Upper Thermocouple Readings for Rod 3 of IFA-432 from November 28, 1978, to January 26, 1979 


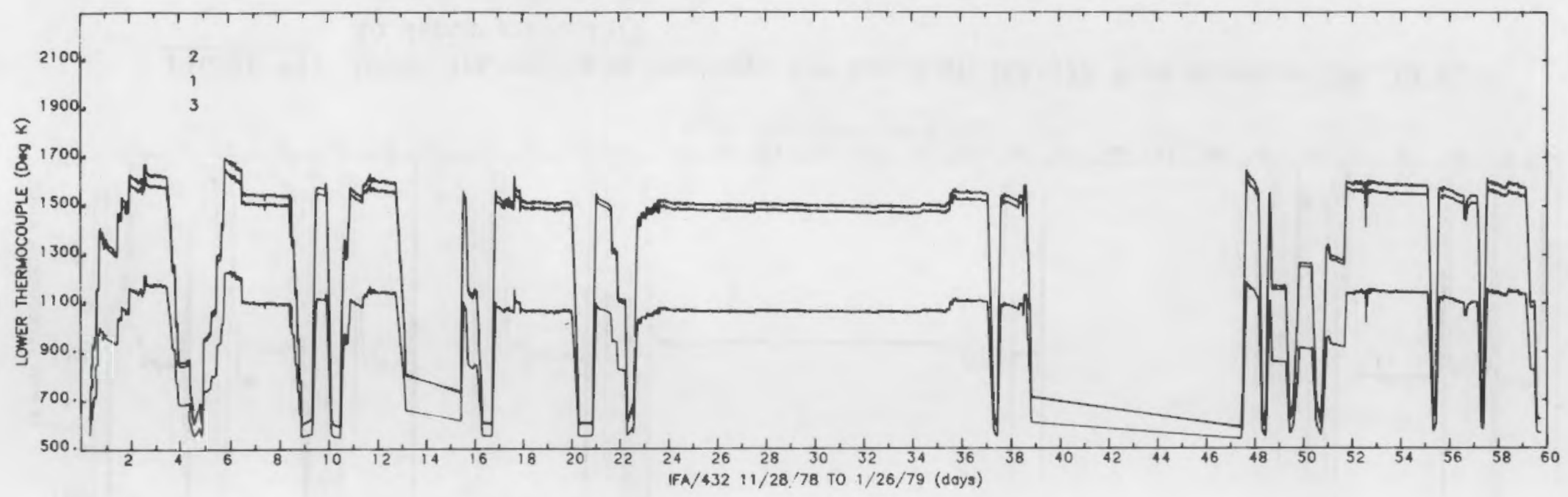

FIGURE 50. Lower Thermocouple Readings for Rods 1, 2, and 3 of IFA-432 from November 28, 1978, to January 26, 1979

$\omega_{\infty}$

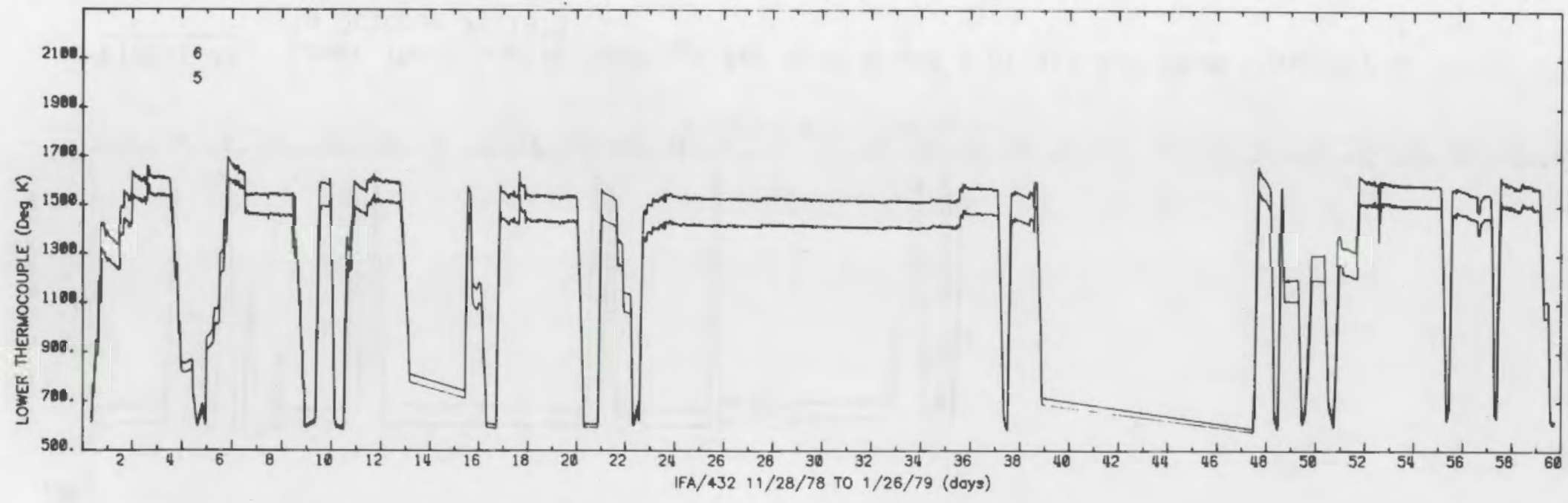

FIGURE 51. Lower Thermocouple Readings for Rods 5 and 6 of IFA-432 from November 28, 1978, to January 26, 1979 


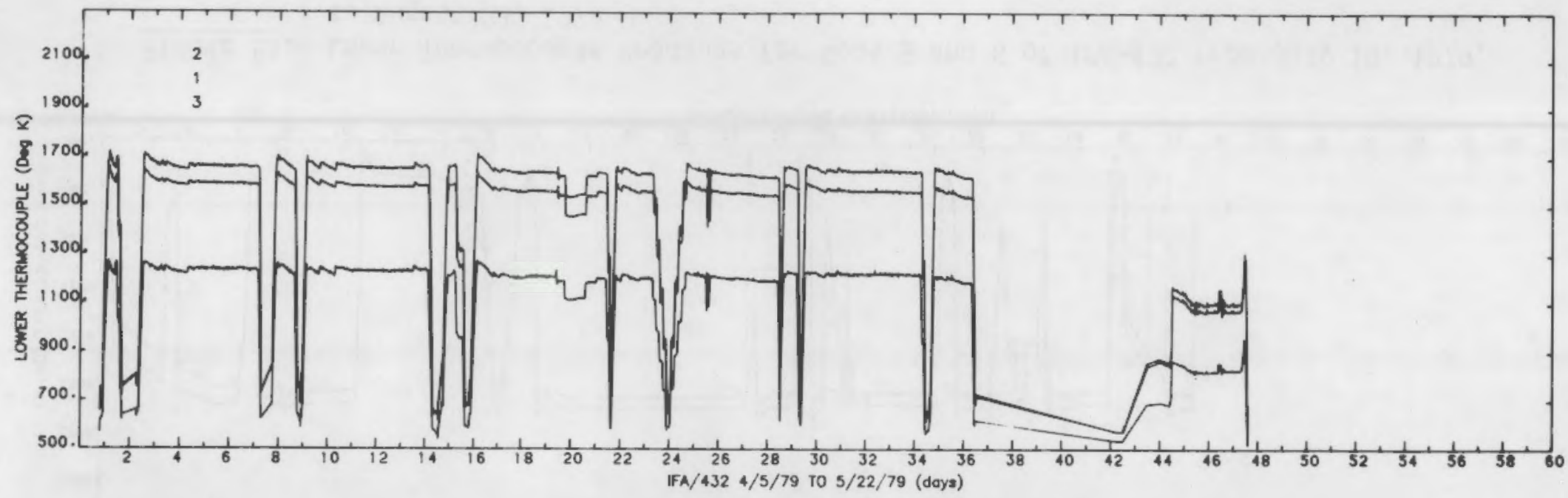

FIGURE 52. Lower Thermocouple Readings for Rods 1, 2, and 3 of IFA-432 from April 5, 1979, $\tilde{\omega}$

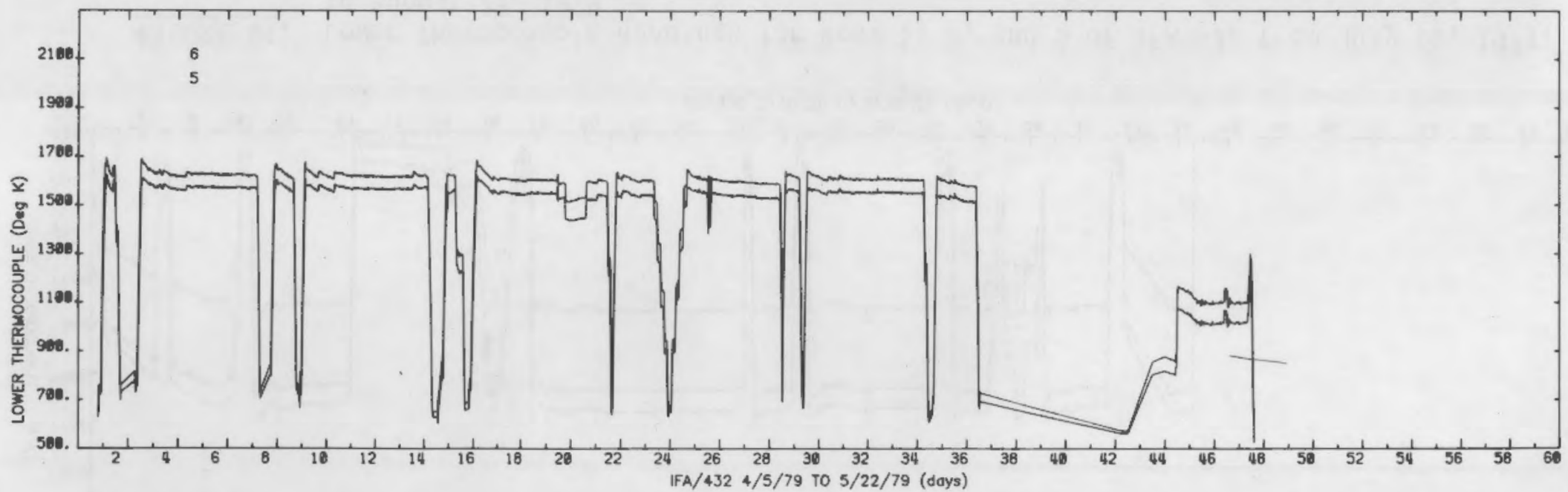

FIGURE 53. Lower Thermocouple Readings for Rods 5 and 6 of IFA-432 from April 5, 1979, to May 22, 1979 


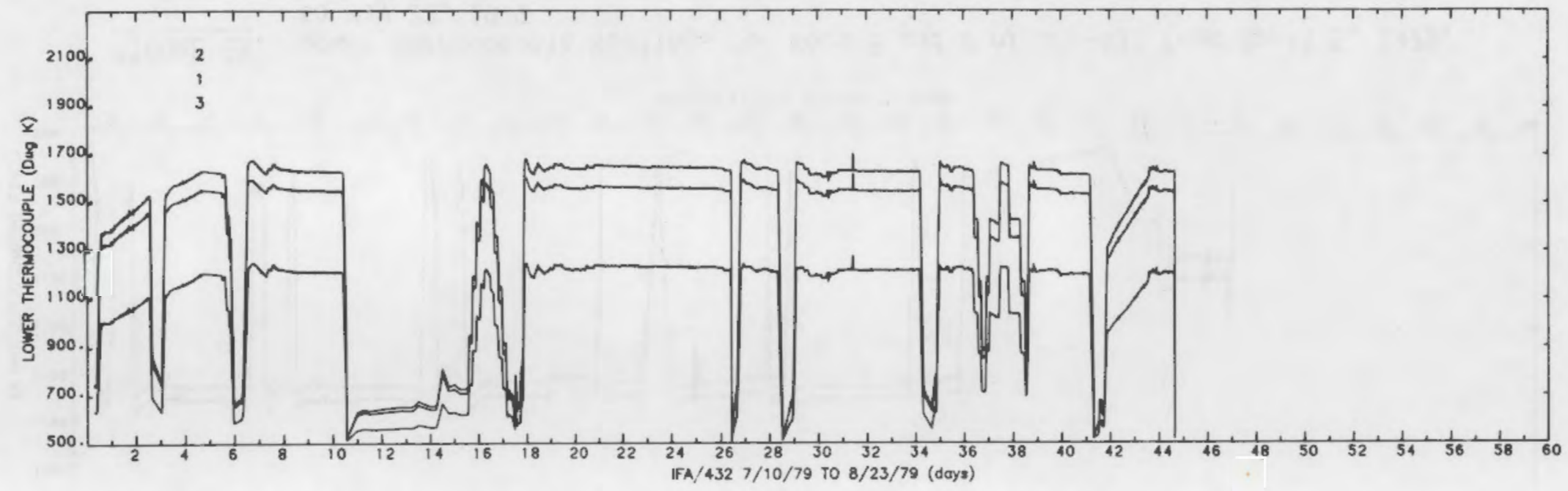

FIGURE 54. Lower Thermocouple Readings for Rods 1, 2, and 3 of IFA-432 from July 10, 1979, to August 23, 1979

o

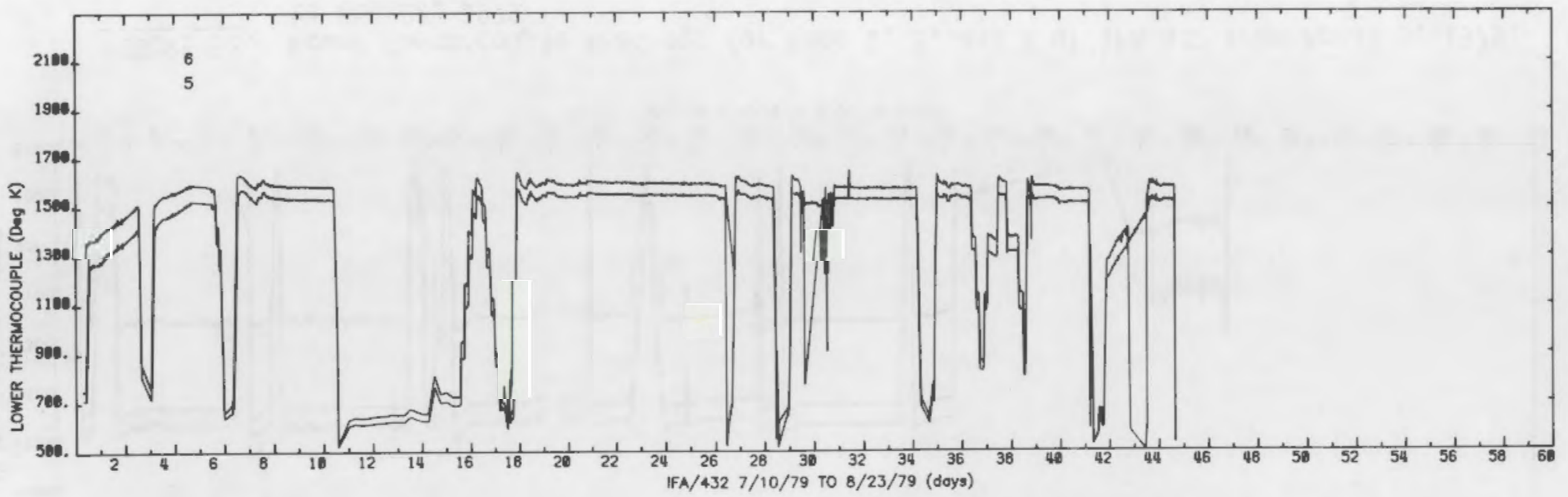

FIGURE 55. Lower Thermocouple Readings for Rods 5 and 6 of IFA-432 from July 10, 1979, to August 23, 1979 


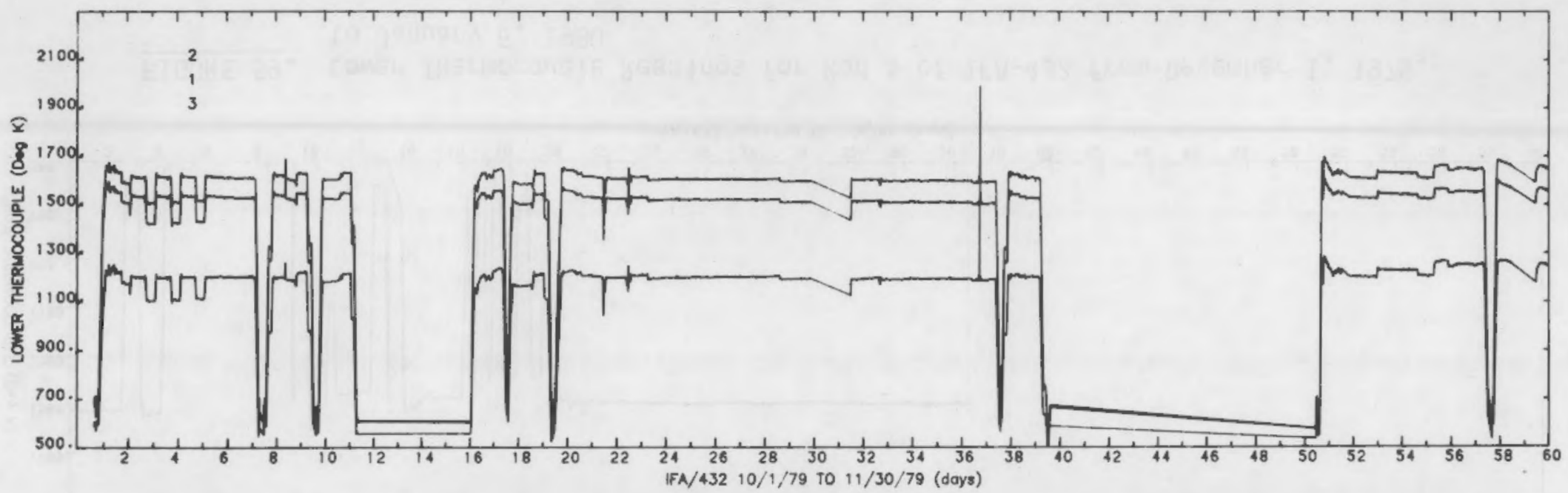

FIGURE 56. Lower Thermocouple Readings for Rods 1, 2, and 3 of IFA-432 from October 1, 1979, to November 30, 1979

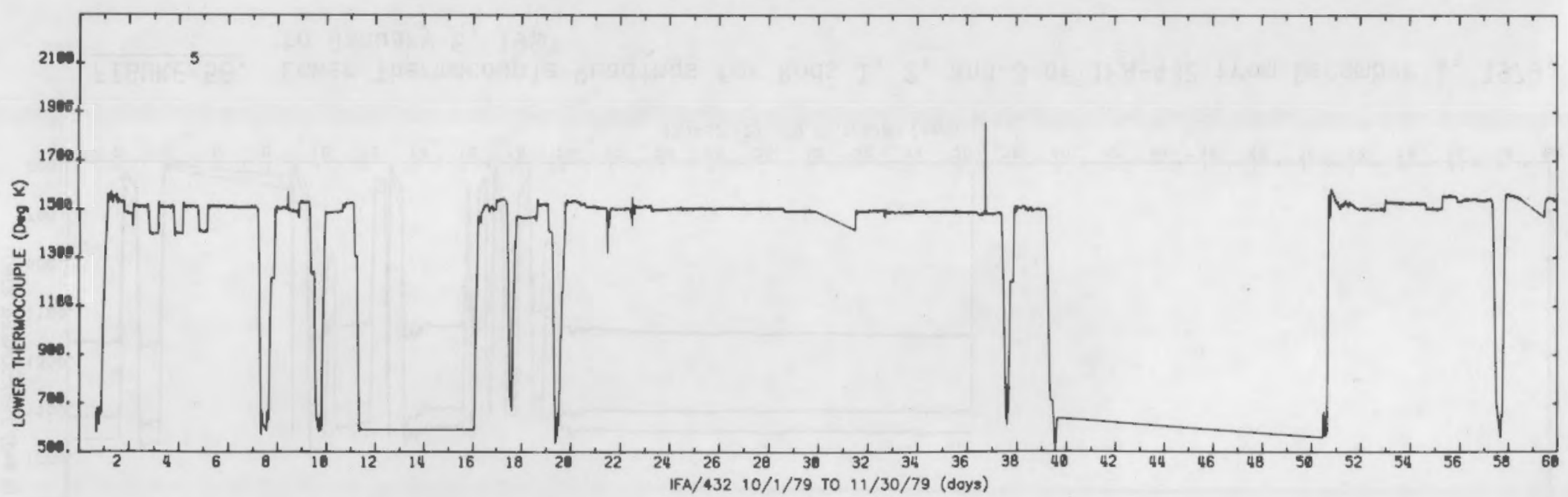

FIGURE 57. Lower Thermocouple Readings for Rod 5 of IFA-432 from October 1, 1979, to November 30, 1979 


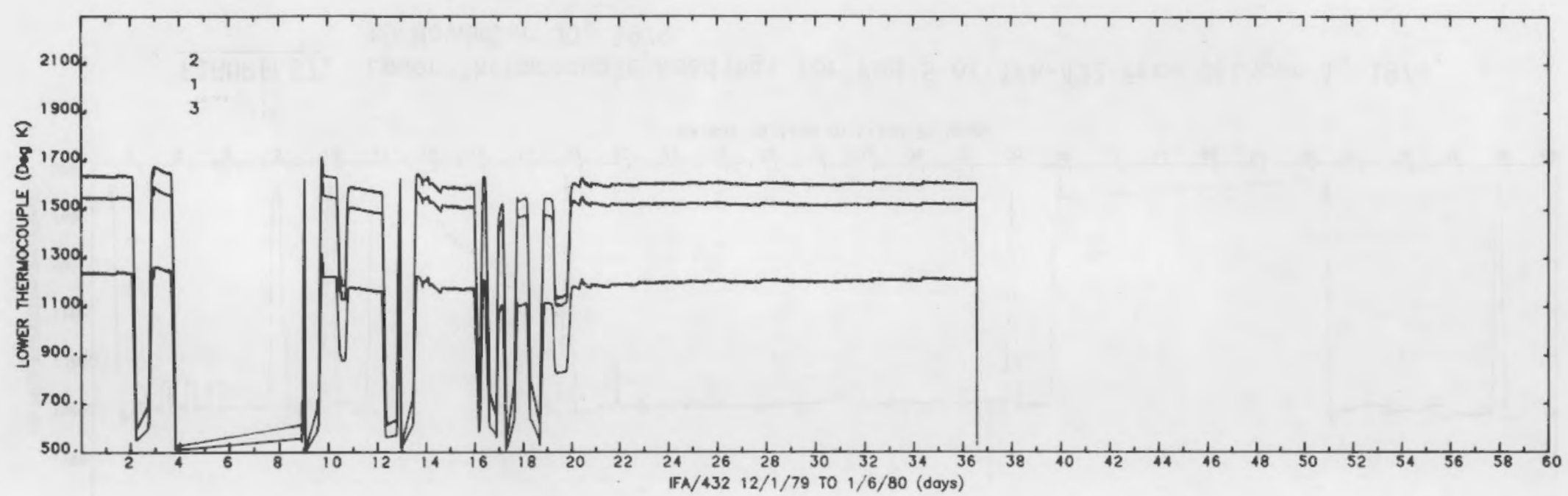

FIGURE 58. Lower Thermocouple Readings for Rods 1, 2, and 3 of IFA-432 from December 1, 1979, to January 6,1980

ㅅ

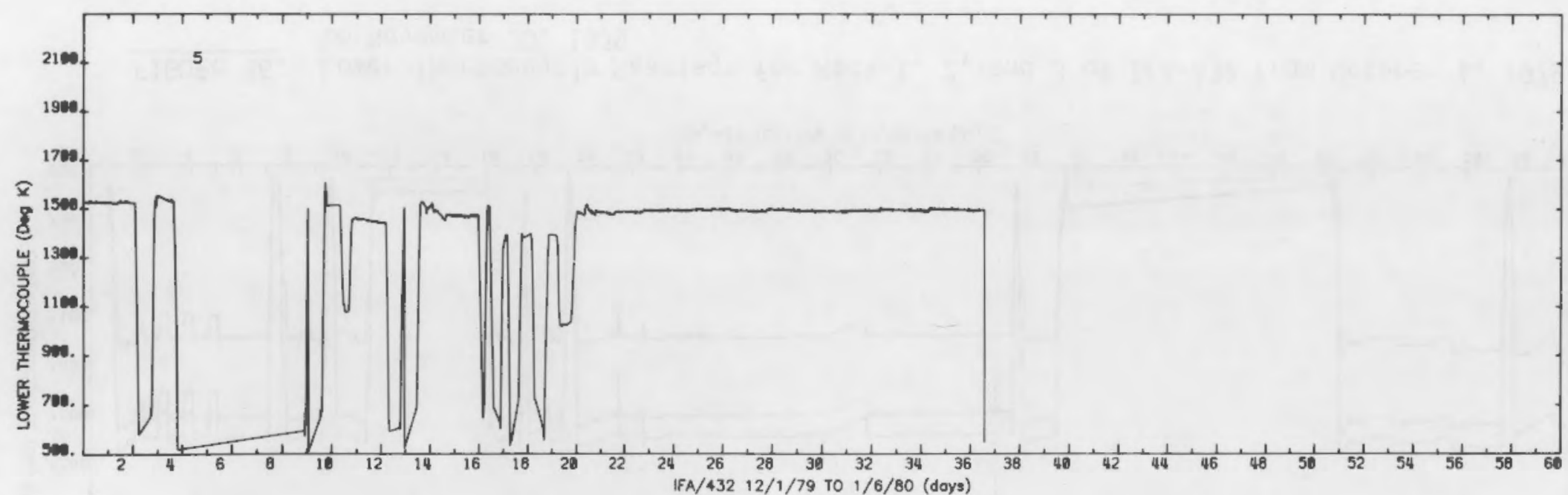

FIGURE 59. Lower Thermocouple Readings for Rod 5 of IFA-432 from December 1, 1979, to January 6,1980 


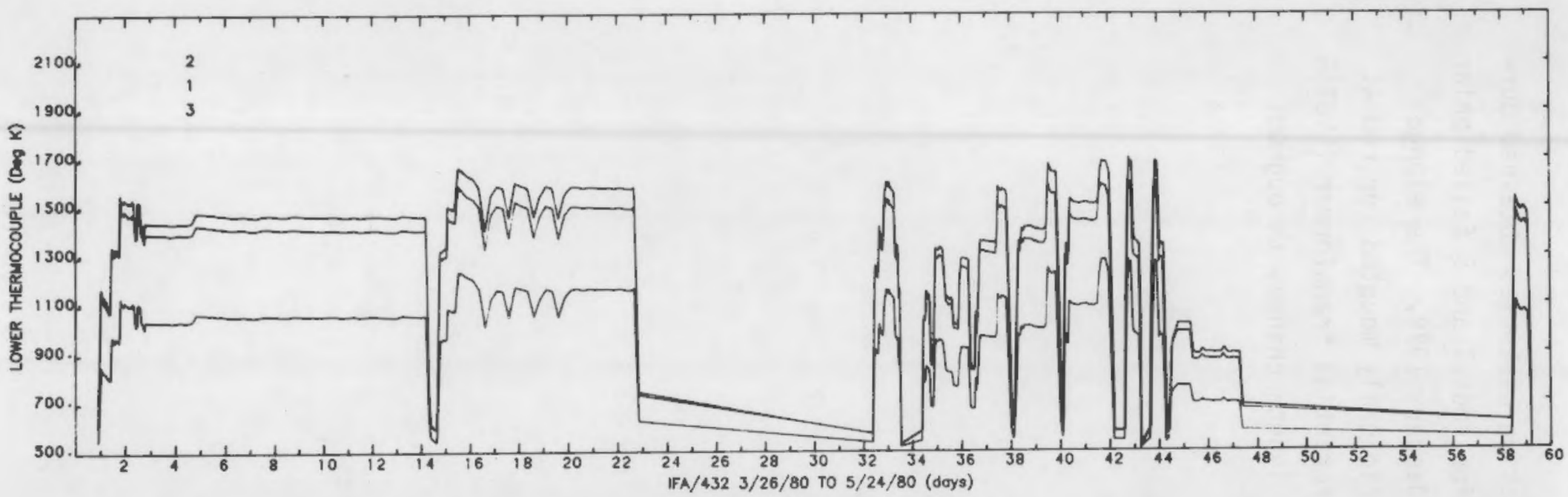

FIGURE 60. Lower Thermocouple Readings for Rods 1, 2, and 3 of IFA-432 from March 26, 1980, to May 24,1980

$\stackrel{\vec{\omega}}{2}$

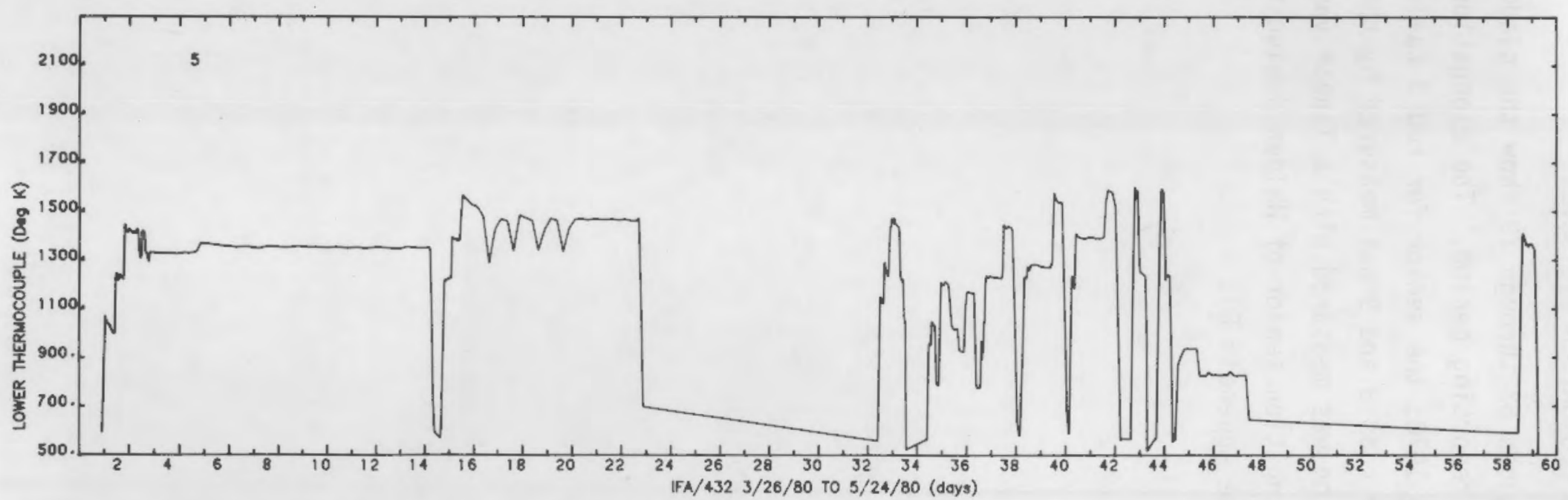

FIGURE 61. Lower Thermocouple Readings for Rod 5 of IFA-432 from March 26, 1980, to May 24, 1980 


\section{CLADDING ELONGATION HISTORIES}

Figures 62 through 79 show the cladding elongation histories obtained during the reporting period. The elongation sensors for rods 1 and 5 failed prior to April 1978; the sensor for rod 3 failed during January 1979. The elongation for rods 8 and 9 was measured by the sensor originally mounted for rod 4 . Elongation was measured with a linear variable differential transformer (LVDT)type elongation sensor of Halden design to monitor length changes throughout life (see Appendix C). 


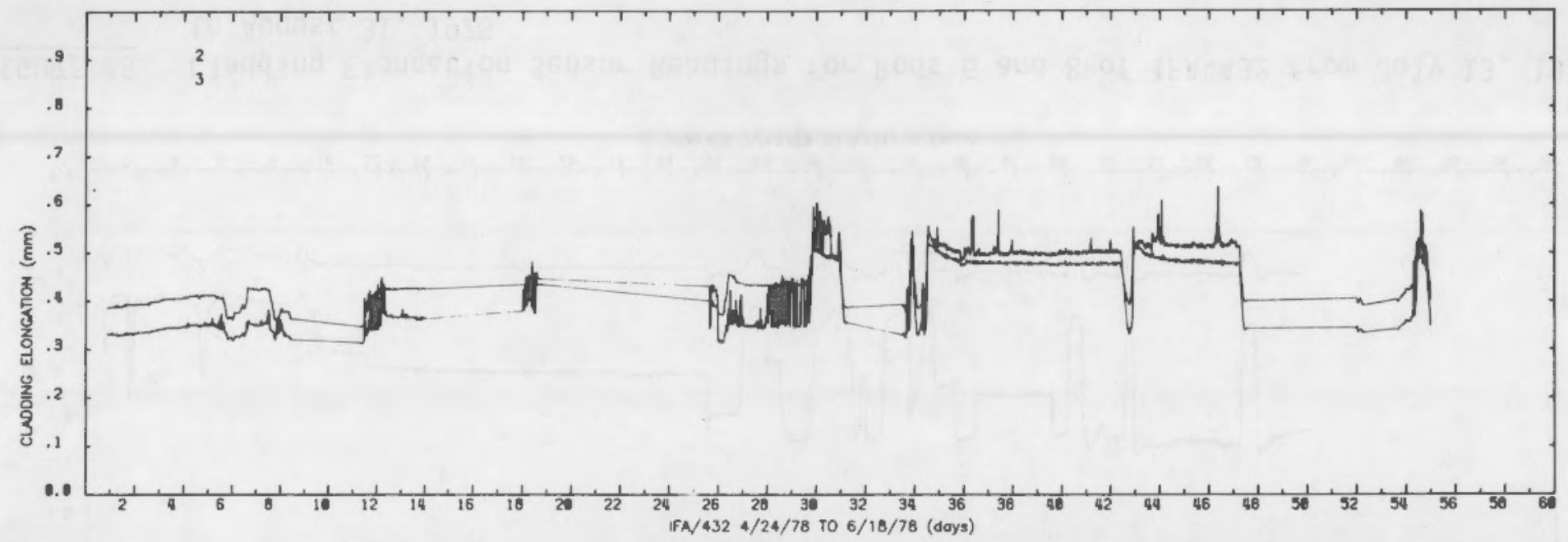

FIGURE 62. Cladding Elongation Sensor Readings for Rods 2 and 3 of IFA-432 from Apri1 24, 1978, to June 18,1978

ज

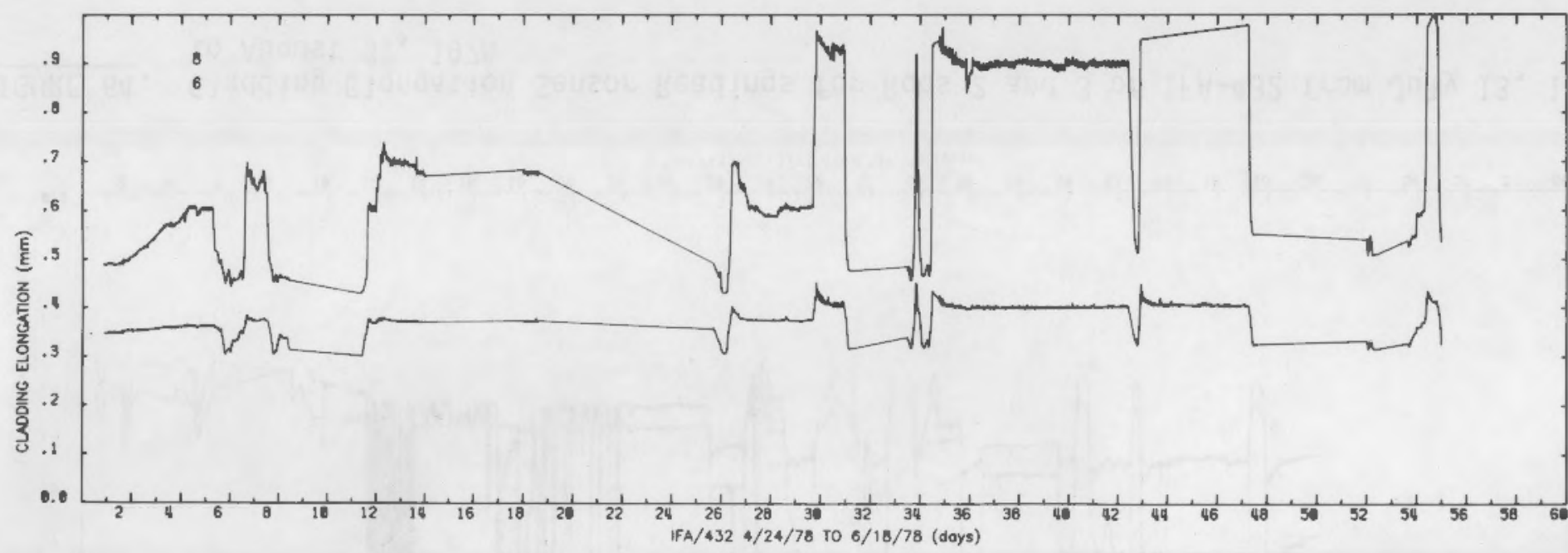

FIGURE 63. Cladding Elongation Sensor Readings for Rods 6 and 8 of IFA-432 from April 24, 1978, to June 18,1978 


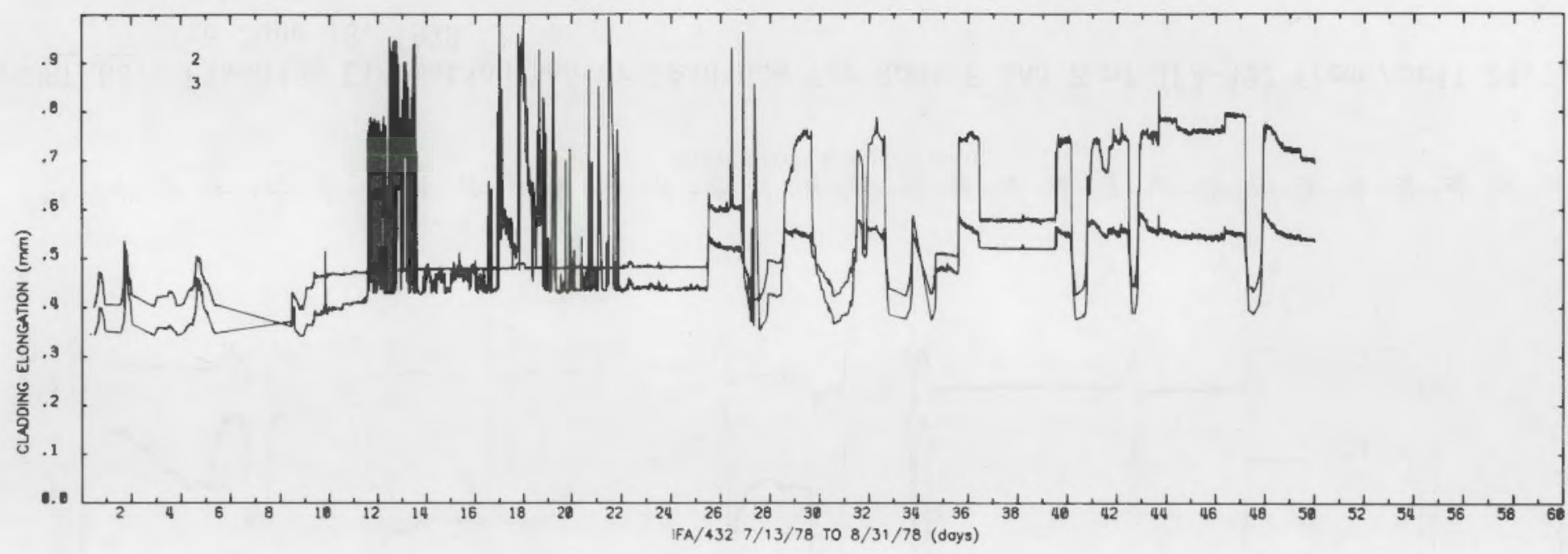

FIGURE 64. Cladding Elongation Sensor Readings for Rods 2 and 3 of IFA-432 from July 13, 1978, to August 31, 1978

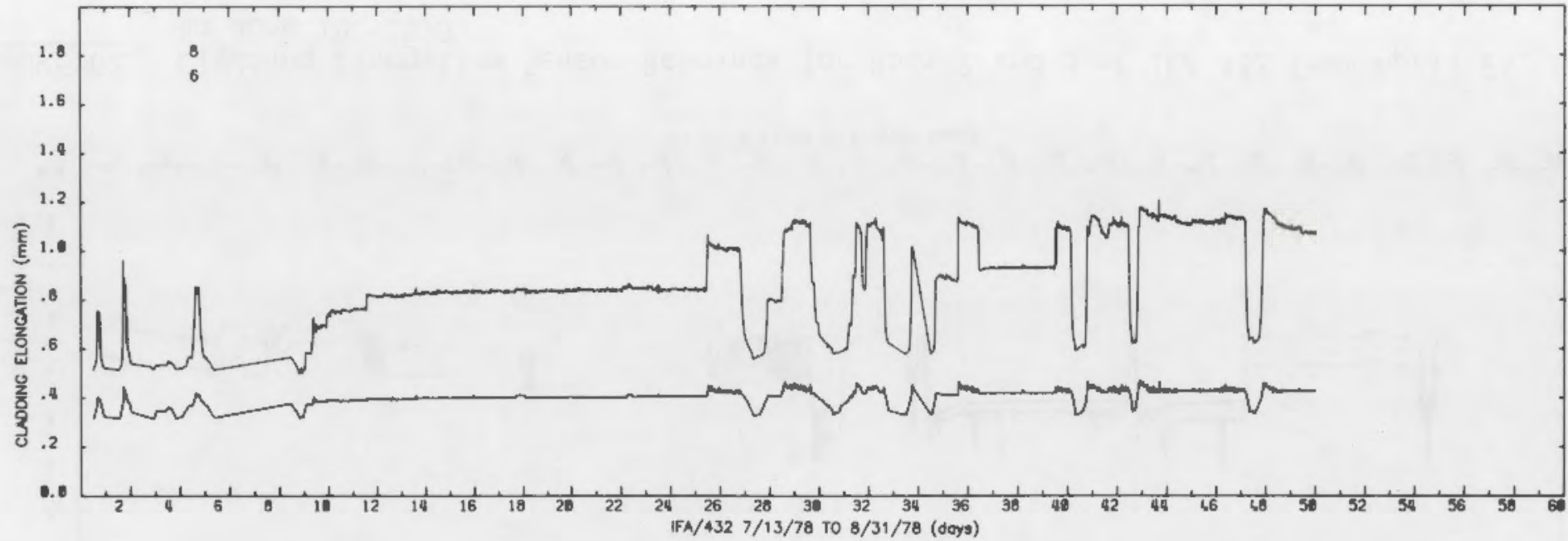

FIGURE 65. Cladding Elongation Sensor Readings for Rods 6 and 8 of IFA-432 from July 13, 1978, to August 31,1978 


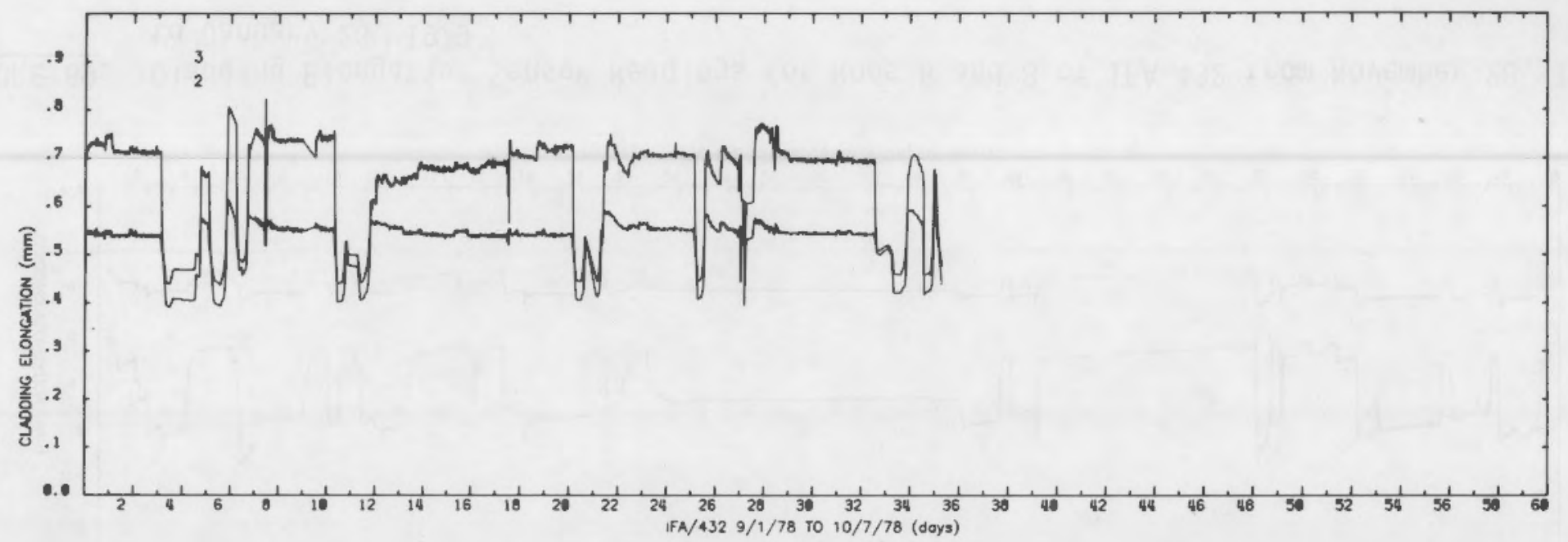

FIGURE 66. Cladding Elongation Sensor Readings for Rods 2 and 3 of IFA-432 from September 1, 1978, to October 7, 1978

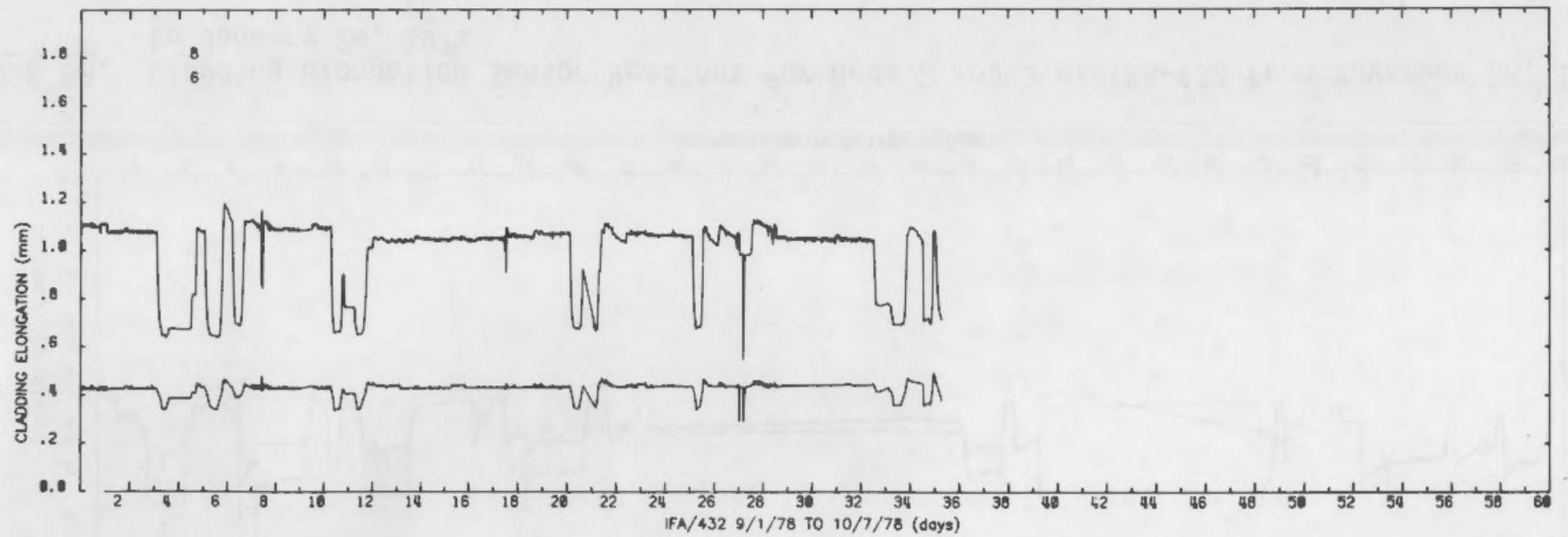

FIGURE 67. Cladding Elongation Sensor Readings for Rods 6 and 8 of IFA-432 from September 1, 1978, to October 7, 1978 


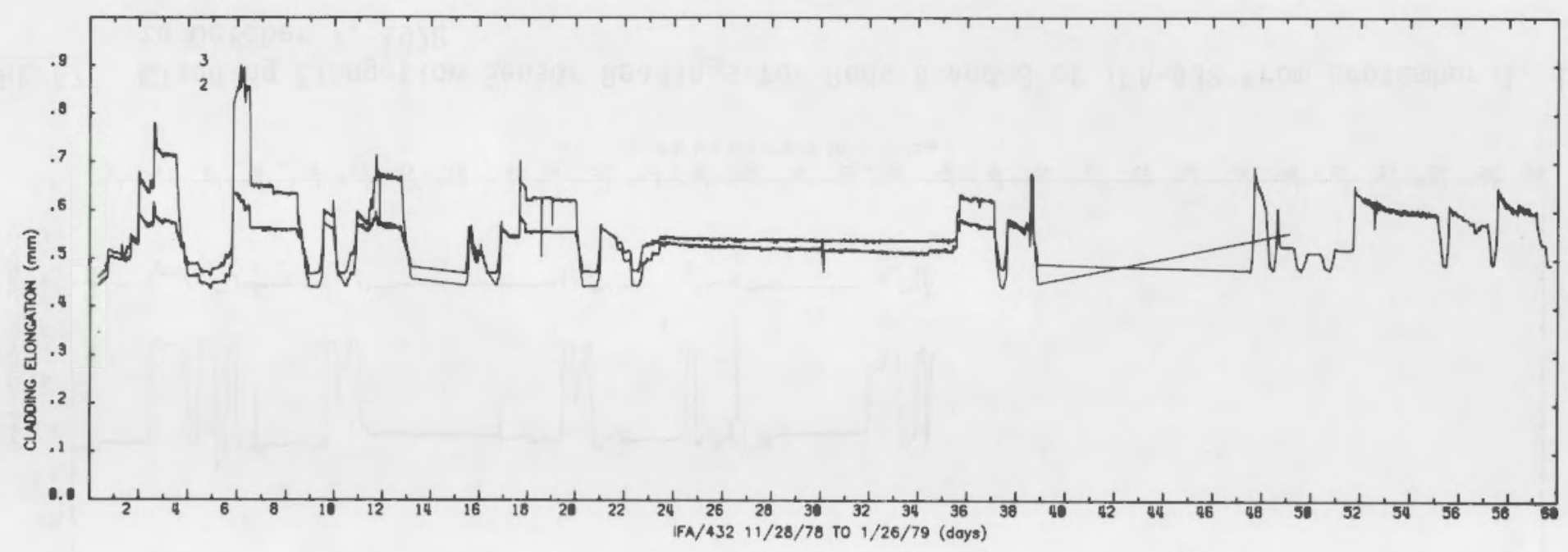

FIGURE 68. Cladding Elongation Sensor Readings for Rods 2 and 3 of IFA-432 from November 28, 1978, to January 26,1979

$\stackrel{\infty}{\infty}$

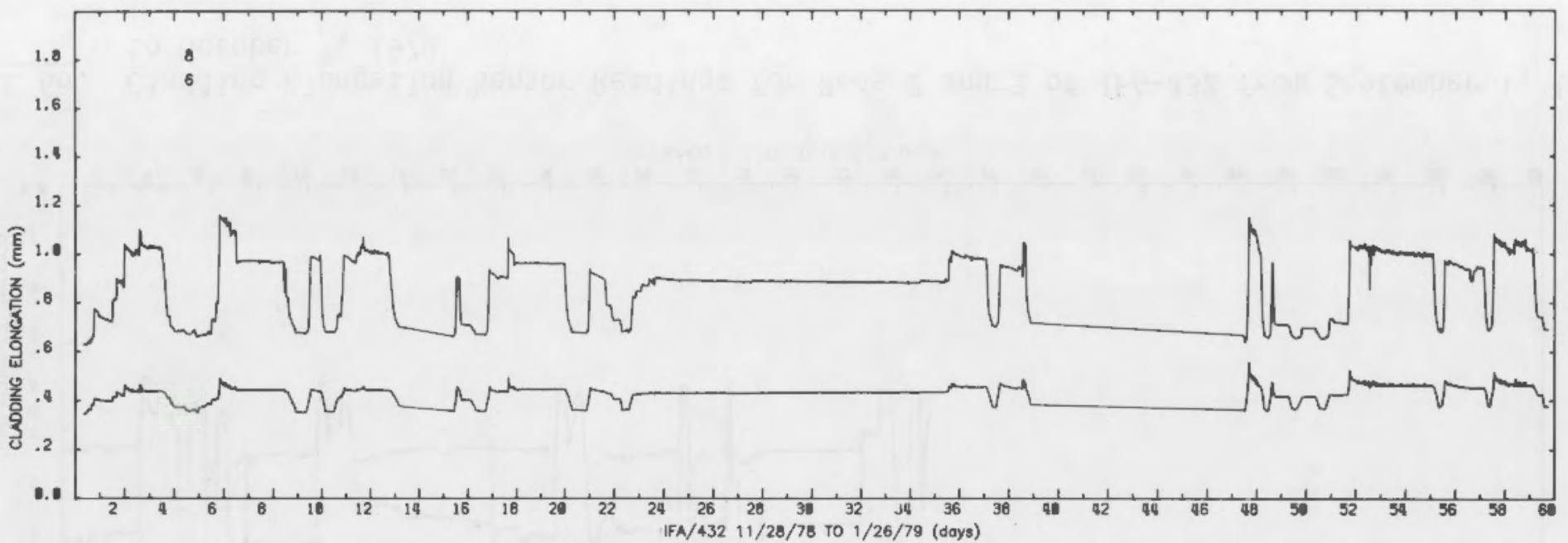

FIGURE 69. Cladding Elongation Sensor Readings for Rods 6 and 8 of IFA-432 from November 28, 1978, to January 26,1979 


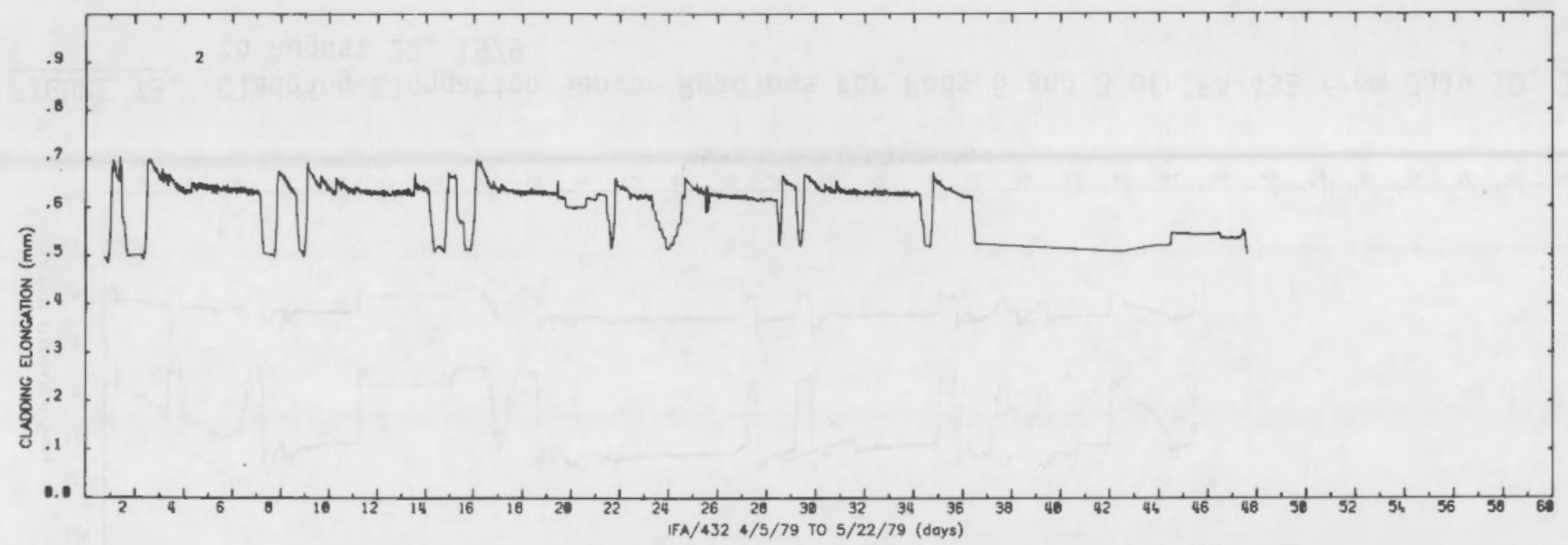

FIGURE 70. Cladding Elongation Sensor Readings for Rod 2 of IFA-432 from April 5, 1979, to May 22, 1979

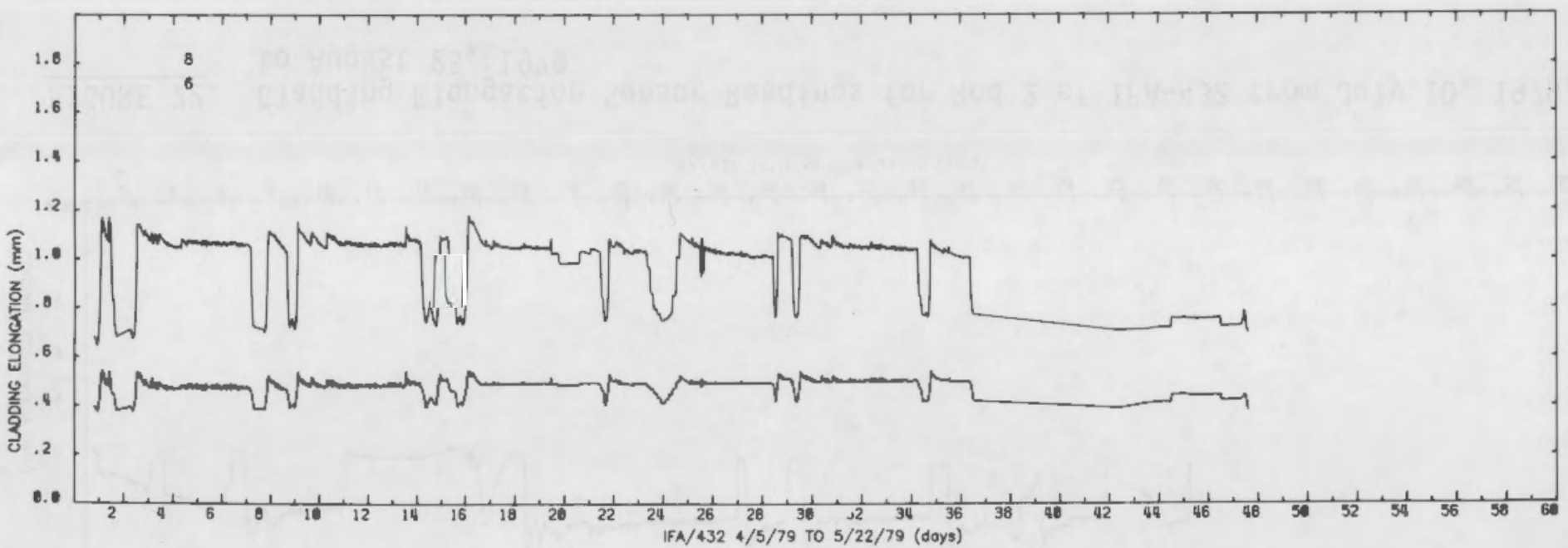

FIGURE 71. Cladding Elongation Sensor Readings for Rods 6 and 8 of IFA-432 from April 5, 1979 , to May 22, 1979 


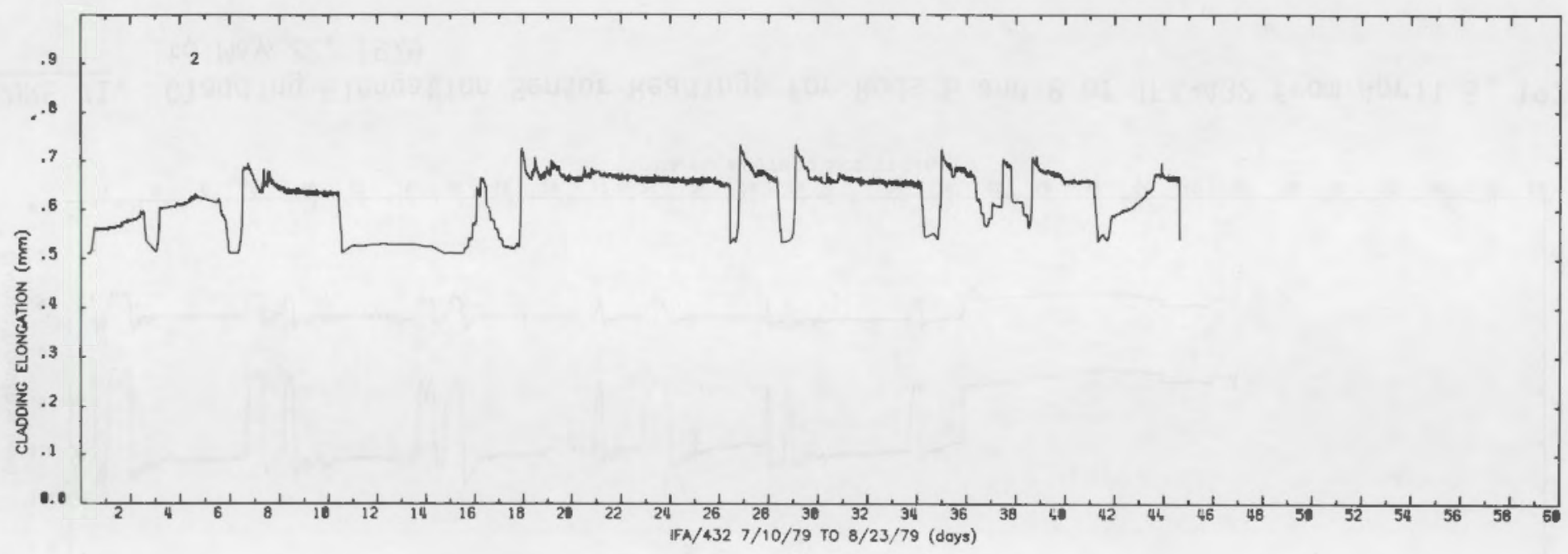

FIGURE 72. Cladding Elongation Sensor Readings for Rod 2 of IFA-432 from July 10, 1979, to August 23, 1979

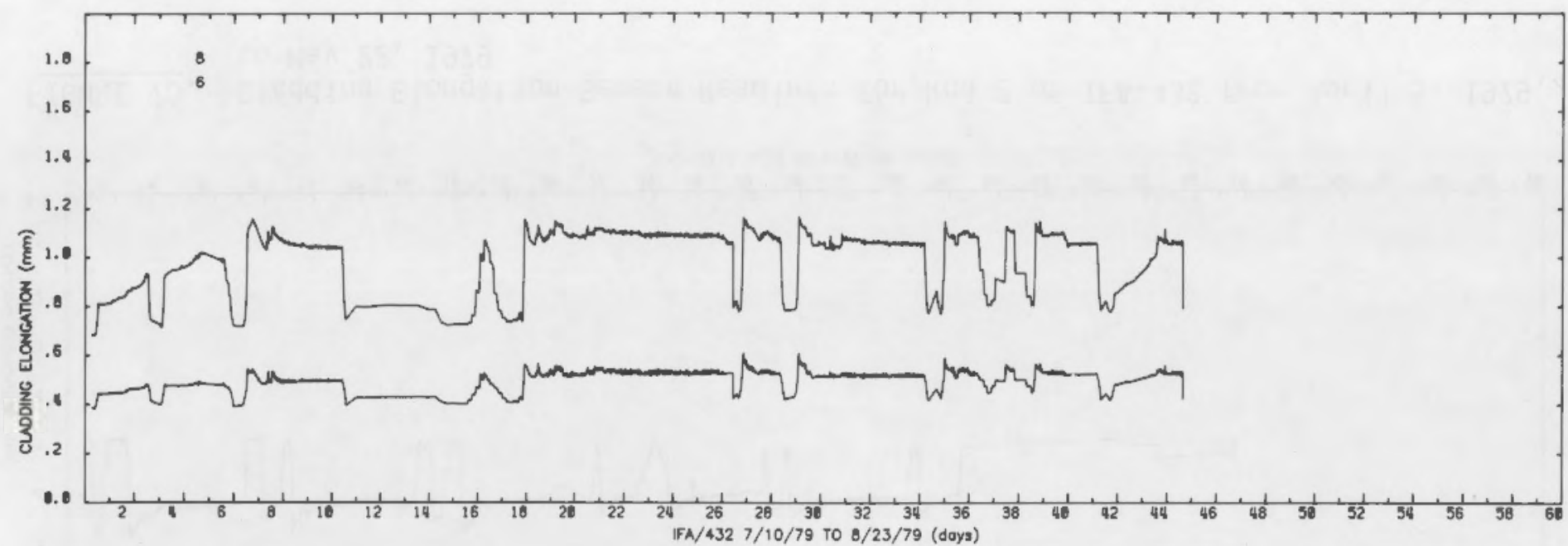

FIGURE 73. Cladding Elongation Sensor Readings for Rods 6 and 8 of IFA-432 from July 10, 1979, to August 23, 1979 


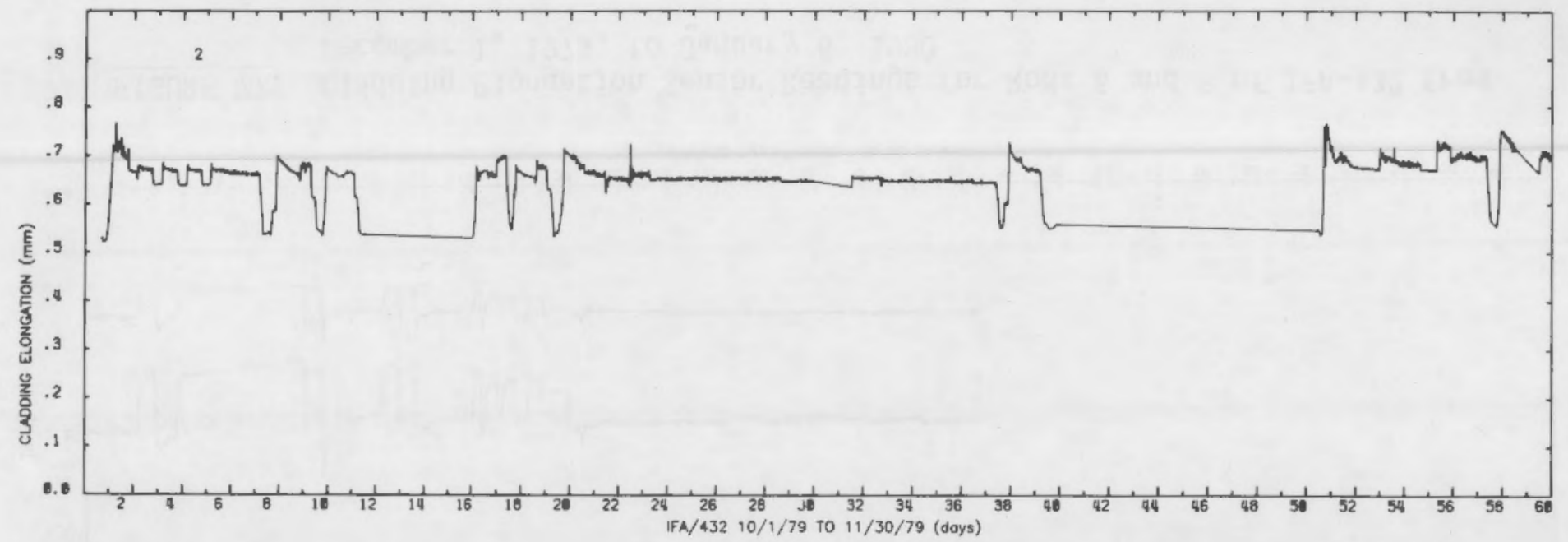

FIGURE 74. Cladding Elongation Sensor Readings for Rod 2 of IFA-432 from October 1, 1979, to November 30, 1979

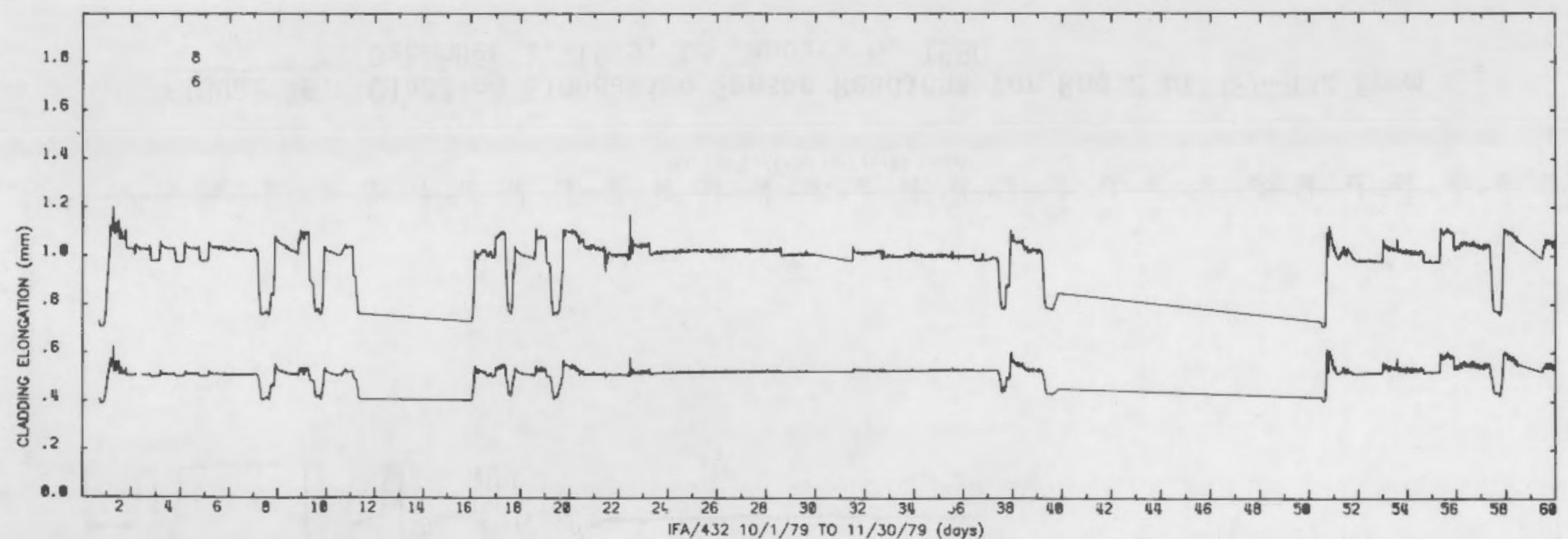

FIGURE 75. Cladding Elongation Sensor Readings for Rods 6 and 8 of IFA-432 from 0ctober 1, 1979, to November 30, 1979 


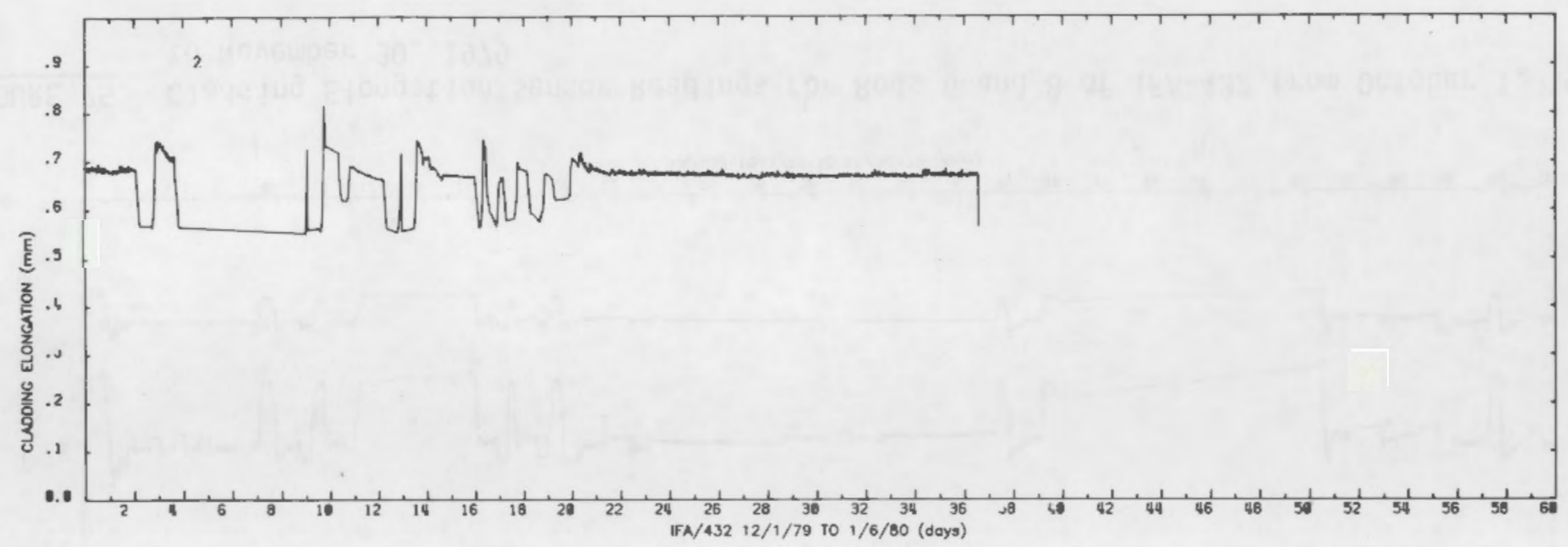

FIGURE 76. Cladding Elongation Sensor Readings for Rod 2 of IFA-432 from December 1, 1979, to January 6, 1980

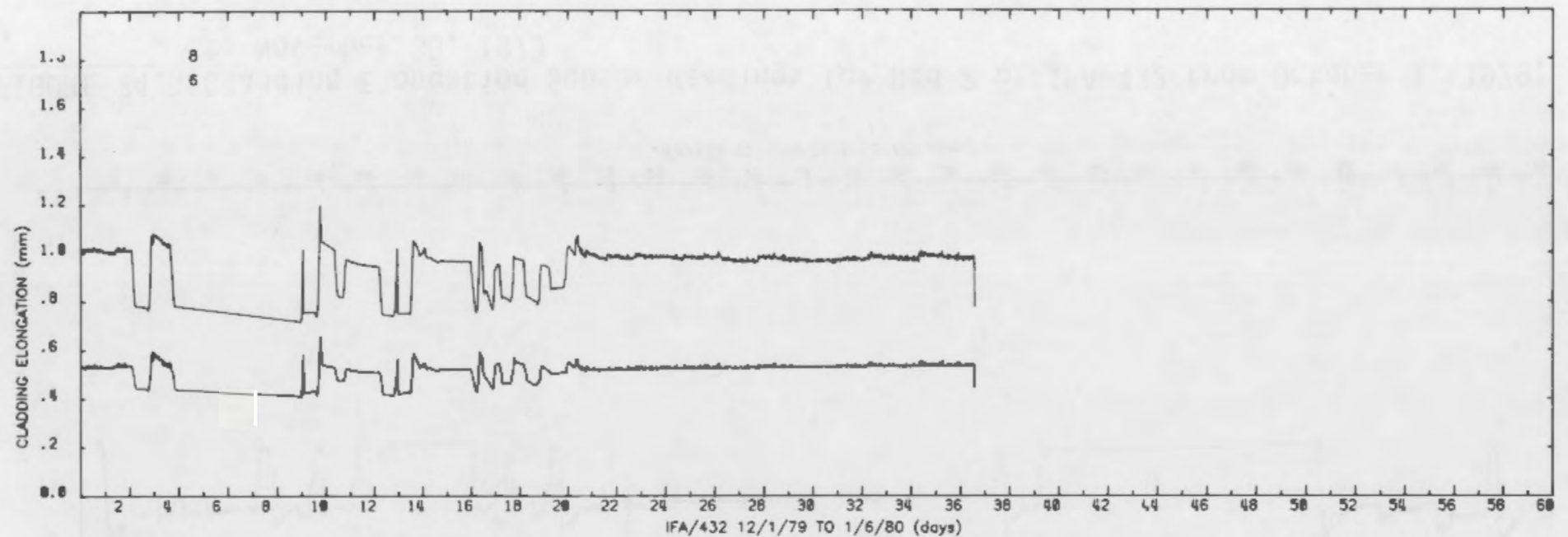

FIGURE 77. Cladding Elongation Sensor Readings for Rods 6 and 8 of IFA-432 from December 1, 1979, to January 6, 1980 


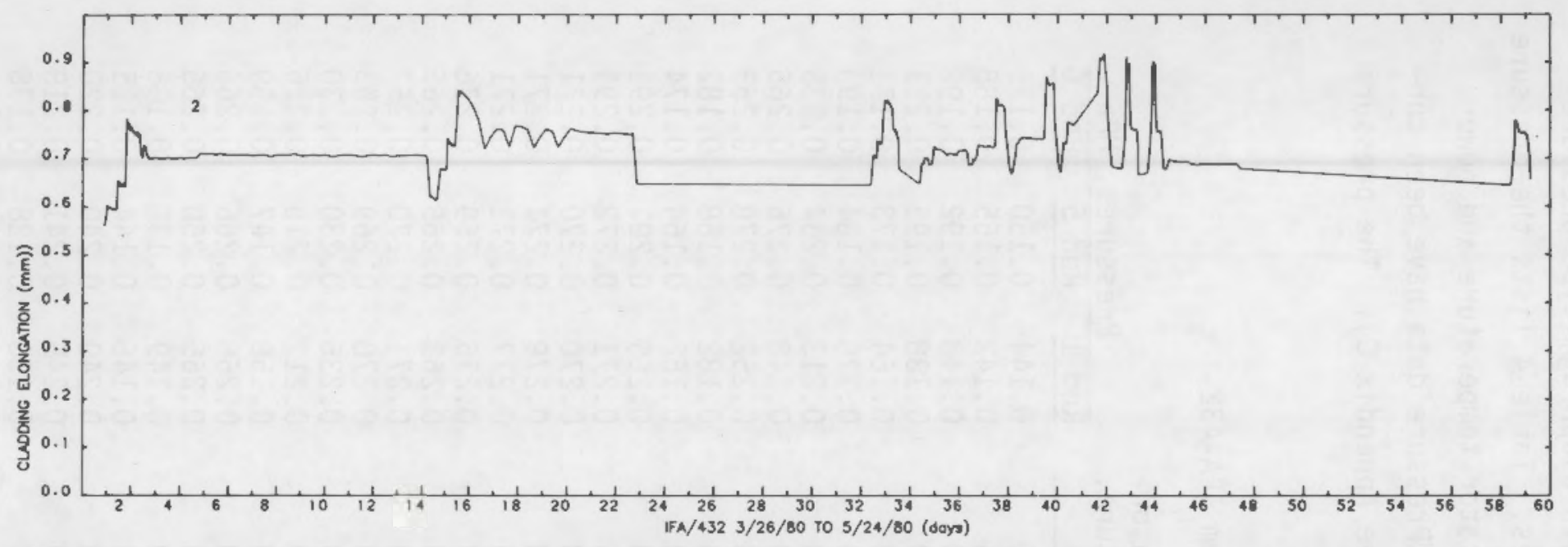

FIGURE 78. Cladding Elongation Sensor Readings for Rod 2 of IFA-432 from March 26, 1980, to May 24, 1980

ज

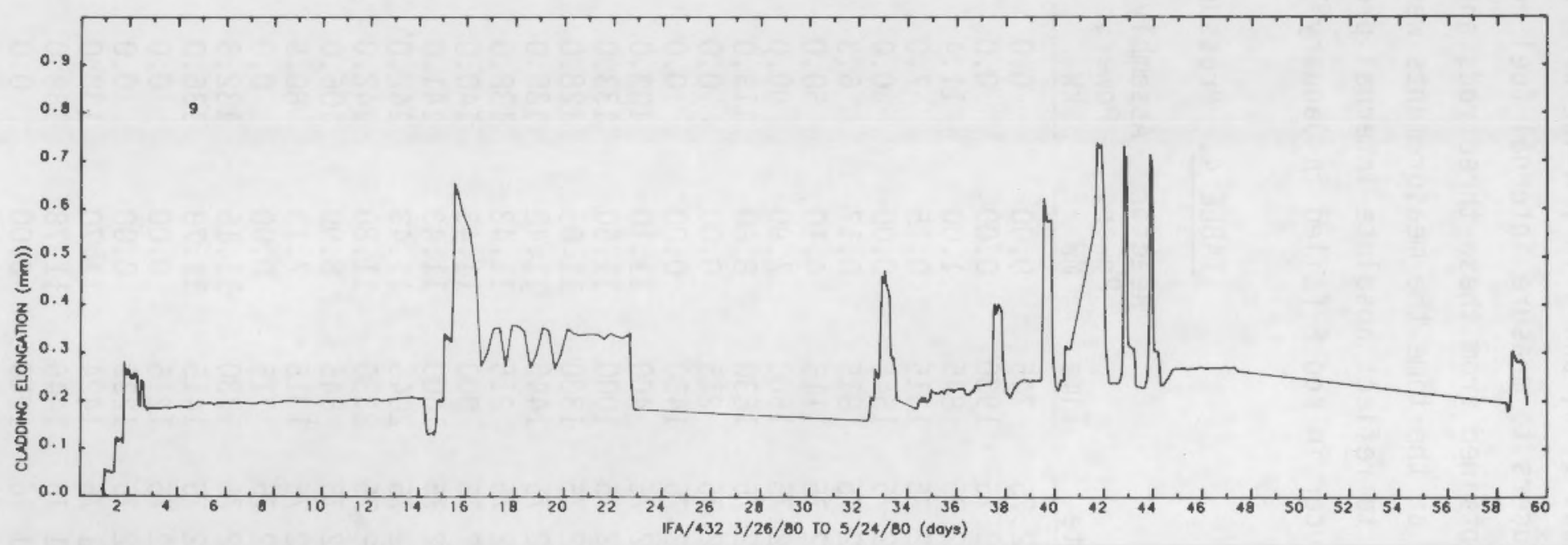

FIGURE 79. Cladding Elongation Sensor Readings for Rod 9 of IFA-432 from March 26, 1980, to May 24, 1980 
ROD INTERNAL PRESSURE HISTORIES

Rods 1, 5, and 6 in IFA-432 were equipped with diaphragm-type pressure transducers to measure internal fuel rod pressures. Table 4 lists the pressure data obtained from these three rods and the moderator temperature and power levels at the time the measurements were taken. Pressure data have been corrected to reflect absolute internal pressures (see Appendix $C$ ). The pressure transducer in rod 6 failed in January 1979.

TABLE 4. Pressure Data from IFA-432

\begin{tabular}{|c|c|c|c|c|c|c|c|}
\hline Date & Time & $\begin{array}{c}\text { Reactor } \\
\text { Power, } \\
\text { MW }\end{array}$ & $\begin{array}{l}\text { Assembly } \\
\text { Power, } \\
\text { kw }\end{array}$ & $\begin{array}{l}\text { Moderator } \\
\text { Temperature, } \\
{ }^{\circ} \mathrm{C}\end{array}$ & \multicolumn{3}{|c|}{ Pressures, MPa } \\
\hline 11275 & 745 & 0.00 & 0.0 & 150.0 & 0.144 & 0.150 & 0.175 \\
\hline 11275 & 1930 & 0.00 & 0.0 & 153.6 & 0.142 & 0.155 & 0.188 \\
\hline 21275 & 845 & 1.00 & 11.4 & 108.0 & 0.148 & 0.192 & 0.192 \\
\hline 71275 & 1315 & 0.15 & 7.0 & 240.0 & 0.138 & 0.193 & 0.211 \\
\hline 71275 & 1545 & 0.00 & 0.0 & 235.0 & 0.164 & 0.173 & 0.171 \\
\hline 81275 & 815 & 0.17 & 6.3 & 240.0 & 0.178 & 0.184 & 0.193 \\
\hline 81275 & 1115 & 4.10 & 50.0 & 238.0 & 0.213 & 0.234 & 0.235 \\
\hline 81275 & 1500 & 7.90 & 99.0 & 238.0 & 0.248 & 0.276 & 0.265 \\
\hline 81275 & 1630 & 8.80 & 113.0 & 232.0 & 0.252 & 0.278 & 0.253 \\
\hline 91275 & 215 & 0.00 & 0.0 & 221.0 & 0.182 & 0.168 & 0.182 \\
\hline 131275 & 1430 & 0.00 & 0.0 & 231.0 & 0.162 & 0.164 & 0.174 \\
\hline 151275 & 400 & 11.10 & 133.0 & 237.0 & 0.265 & 0.291 & 0.291 \\
\hline $15 \quad 1275$ & 1000 & 11.50 & 133.0 & 237.0 & 0.271 & 0.272 & 0.291 \\
\hline 151275 & 1330 & 11.05 & 128.0 & 237.0 & 0.270 & 0.270 & 0.271 \\
\hline $15 \quad 1275$ & 1445 & 11.42 & 135.0 & 237.0 & 0.279 & 0.271 & 0.271 \\
\hline $16 \quad 1275$ & 215 & 11.42 & 138.0 & 237.0 & 0.277 & 0.271 & 0.271 \\
\hline 161275 & 900 & 11.43 & 140.0 & 237.0 & 0.275 & 0.269 & 0.276 \\
\hline 161275 & 1600 & 11.43 & 141.0 & 237.0 & 0.263 & 0.265 & 0.265 \\
\hline $16 \quad 1275$ & 2045 & 11.43 & 142.0 & 237.0 & 0.271 & 0.270 & 0.257 \\
\hline 161275 & 2330 & 11.80 & 142.0 & 236.0 & 0.270 & 0.269 & 0.253 \\
\hline 171275 & 845 & 8.99 & 106.0 & 236.0 & 0.236 & 0.230 & 0.230 \\
\hline 171275 & 1315 & 7.13 & 80.5 & 237.0 & 0.217 & 0.216 & 0.216 \\
\hline 181275 & 715 & 0.00 & 0.0 & 229.0 & 0.158 & 0.147 & 0.159 \\
\hline $19 \quad 1275$ & 730 & 11.15 & 132.3 & 237.0 & 0.266 & 0.266 & 0.266 \\
\hline 191275 & 1415 & 11.78 & 136.0 & 236.0 & 0.265 & 0.250 & 0.265 \\
\hline $\begin{array}{lll}30 & 12 & 75\end{array}$ & 1215 & 0.00 & 0.0 & 222.0 & 0.149 & 0.138 & 0.108 \\
\hline $\begin{array}{lll}30 & 12 & 75\end{array}$ & 1230 & 0.00 & 0.0 & 222.0 & 0.146 & 0.144 & 0.115 \\
\hline 20176 & 1424 & 11.70 & 138.0 & 236.0 & 0.240 & 0.240 & 0.220 \\
\hline 20176 & 1446 & 11.78 & 138.0 & 236.0 & 0.245 & 0.241 & 0.218 \\
\hline 70176 & 1000 & 0.00 & 0.0 & 222.0 & 0.138 & 0.128 & 0.138 \\
\hline 70176 & 1015 & 0.00 & 0.0 & 220.0 & 0.142 & 0.136 & 0.142 \\
\hline 230176 & 2130 & 0.00 & 1.1 & 226.0 & 0.128 & 0.119 & 0.108 \\
\hline
\end{tabular}


TABLE 4. (contd)

\begin{tabular}{|c|c|c|c|c|c|c|c|}
\hline Date & Iime & $\begin{array}{l}\text { Reactor } \\
\text { Power, } \\
\text { MW }\end{array}$ & $\begin{array}{c}\text { Assembly } \\
\text { Power, } \\
\mathrm{KW} \\
\end{array}$ & $\begin{array}{l}\text { Moderator } \\
\text { Temperature, } \\
{ }^{\circ} \mathrm{C}\end{array}$ & Rod & Rod 5 & $\frac{M P a}{\operatorname{Rod} 6}$ \\
\hline $\begin{array}{lll}24 & 01 & 76\end{array}$ & 1630 & 11.30 & 138.0 & 236.0 & 0.210 & 0.210 & 0.210 \\
\hline 240176 & 1645 & 11.20 & 138.0 & $23 \mathrm{E}$ & 0.210 & 0.210 & 0.210 \\
\hline $\begin{array}{lll}502 & 76\end{array}$ & 1600 & 0.00 & 0.0 & 232.0 & 0.108 & 0.108 & 0.108 \\
\hline 60276 & 1440 & 9.30 & 113.0 & 235.0 & 0.179 & 0.189 & 0.199 \\
\hline 130276 & 530 & 7.20 & 84.0 & 235.0 & 0.179 & 0.189 & 0.189 \\
\hline $\begin{array}{lll}15 & 02 & 76\end{array}$ & 1500 & 0.00 & 0.0 & 232.0 & 0.119 & 0.119 & 0.119 \\
\hline $\begin{array}{lll}25 & 06 & 76\end{array}$ & 730 & 0.00 & 0.0 & 227.0 & 0.131 & 0.125 & \\
\hline $\begin{array}{lll}28 & 06 & 76\end{array}$ & 1500 & 12.21 & 140.0 & 240.0 & 0.157 & 0.185 & 0.190 \\
\hline 60876 & 1340 & 11.82 & 140.0 & 321.0 & 0.169 & 0.270 & 0.231 \\
\hline $10 \quad 0876$ & 1615 & 11.50 & 139.0 & 230.0 & 0.199 & 0.311 & 0.271 \\
\hline $\begin{array}{lll}18 & 08 & 76\end{array}$ & 730 & 0.00 & 0.0 & 225.0 & 0.128 & 0.210 & 0.19 \\
\hline $\begin{array}{lll}18 & 08 & 76\end{array}$ & 800 & 0.00 & 0.0 & 225.0 & 0.103 & 0.180 & 0.17 \\
\hline $\begin{array}{lll}22 & 09 & 76\end{array}$ & 1915 & 0.00 & 0.0 & 234.0 & 0.128 & 0.270 & 0.229 \\
\hline 71076 & 1300 & 0.00 & 0.0 & 227.0 & 0.138 & 0.280 & 0.240 \\
\hline $21 \quad 1076$ & 1300 & 12.30 & 140.0 & 238.0 & 0.280 & 0.695 & 0.52 \\
\hline 291076 & 1015 & 11.82 & 128.0 & 239.0 & 0.237 & 0.688 & 0.517 \\
\hline 291076 & 1930 & 0.00 & 0.0 & 233.0 & 0.138 & 0.356 & 0.31 \\
\hline 71276 & 505 & 2.90 & 9.3 & 238.7 & 0.167 & 0.412 & 0.343 \\
\hline 71276 & 1005 & 4.70 & 41.6 & 240.0 & 0.206 & 0.519 & 0.44 \\
\hline 71276 & 1333 & 9.20 & 109.2 & 240.1 & 0.265 & 0.686 & 0.510 \\
\hline 81276 & 2004 & 3.00 & 13.1 & 239.5 & 0.147 & 0.451 & 0.353 \\
\hline 91276 & 1938 & 11.60 & 123.5 & 240.4 & 0.274 & 0.715 & 0.53 \\
\hline $\begin{array}{lll}10 & 12 & 76\end{array}$ & 1933 & 12.50 & 146.4 & 239.9 & 0.274 & 0.735 & 0.55 \\
\hline $\begin{array}{lll}3 & 01 & 77\end{array}$ & 1434 & 12.40 & 144.0 & 240.1 & 0.304 & 0.843 & 0.70 \\
\hline $\begin{array}{lll}4 & 01 & 77\end{array}$ & 626 & 0.00 & 0.0 & 222.7 & 0.157 & 0.402 & 0.372 \\
\hline $\begin{array}{lll}17 & 01 & 77\end{array}$ & 1033 & 11.80 & 135.9 & 239.7 & 0.314 & 0.862 & 0.75 \\
\hline $\begin{array}{lll}19 & 01 & 77\end{array}$ & 1038 & 3.00 & 33.9 & 237.0 & 0.186 & 0.637 & 0.57 \\
\hline $\begin{array}{lll}19 & 01 & 77\end{array}$ & 1511 & 8.50 & 96.3 & 240.4 & 0.216 & 0.823 & 0.73 \\
\hline $\begin{array}{lll}27 & 01 & 77\end{array}$ & 930 & 11.90 & 144.1 & 239.3 & 0.333 & 0.921 & 0.84 \\
\hline $\begin{array}{lll}4 & 02 & 77\end{array}$ & 1324 & 4. & 66 & & & 94 & 0.73 \\
\hline $\begin{array}{lll}9 & 02 & 77\end{array}$ & 1023 & 11.10 & 139.9 & 239.9 & 0.363 & 0.804 & 0.892 \\
\hline $\begin{array}{lll}25 & 03 & 77\end{array}$ & 1628 & 1.50 & 4.0 & 203.1 & 0.216 & 0.500 & 0.48 \\
\hline $\begin{array}{lll}26 & 03 & 77\end{array}$ & 1233 & 6.50 & 54.8 & 239.3 & 0.314 & 0.784 & 0.71 \\
\hline $\begin{array}{lll}26 & 03 & 77\end{array}$ & 1728 & 12.00 & 116.6 & 239.7 & 0.314 & 0.951 & 0.86 \\
\hline $\begin{array}{lll}10 & 04 & 77\end{array}$ & 1034 & 11.70 & 136.6 & 239.4 & 0.392 & & 0.97 \\
\hline $\begin{array}{lll}14 & 04 & 77\end{array}$ & $14 !$ & 11.5 & 118.6 & 239.2 & 0.382 & 0.892 & 0.97 \\
\hline $\begin{array}{lll}18 & 04 & 77\end{array}$ & 143 & 12.20 & 143.2 & 239.0 & 0.421 & 0.931 & 0.88 \\
\hline $\begin{array}{ll}30577 \\
\end{array}$ & 131 & 6.20 & 85.8 & 238.7 & 0.441 & 0.931 & 0.90 \\
\hline $\begin{array}{lll}11 & 05 & 77\end{array}$ & 133 & 12.00 & 138.3 & 238.9 & 0.568 & 1.205 & 1.11 \\
\hline $\begin{array}{lll}16 & 05 & 77\end{array}$ & $13 !$ & 5.30 & 77.8 & 239.1 & 0.529 & 1.107 & 1.05 \\
\hline $\begin{array}{lll}19 & 05 \quad 77\end{array}$ & 23 & 12.50 & 143.1 & 239.3 & 0.627 & 1.313 & 1.24 \\
\hline $\begin{array}{lll}19 & 05 & 77\end{array}$ & 233 & 12.40 & 143.2 & 239.3 & 0.637 & 1.303 & 1.25 \\
\hline $20 \quad 05 \quad 77$ & 130 & 12.40 & 143.0 & 239.5 & 0.627 & 1.303 & 1.24 \\
\hline $\begin{array}{llll}20 & 05 & 77\end{array}$ & 150 & 12.30 & 144.0 & 239.4 & 0.637 & 1.303 & 1.23 \\
\hline $\begin{array}{lll}21 & 05 & 77\end{array}$ & 28 & 0.00 & 0.0 & 199.6 & 0.314 & 0.637 & 0.657 \\
\hline $\begin{array}{llll}21 & 05 & 77\end{array}$ & 218 & 0.00 & 0.0 & 198.9 & 0.294 & 0.647 & 0.65 \\
\hline
\end{tabular}


IABLE 4. (contd)

\begin{tabular}{|c|c|c|c|c|c|c|c|}
\hline Date & Time & $\begin{array}{l}\text { Power, } \\
\text { MW }\end{array}$ & $\begin{array}{l}\text { Power, } \\
\mathrm{kw}\end{array}$ & $\begin{array}{c}\text { Temperature, } \\
{ }^{\circ} \mathrm{C}\end{array}$ & Rod 1 & $\begin{array}{l}\text { essure } \\
\text { Rod } 5\end{array}$ & $\frac{M P^{2}}{\operatorname{Rod} 6}$ \\
\hline $\begin{array}{lll}21 & 05 & 77\end{array}$ & 1840 & 0.00 & 0.0 & 68.8 & 0.186 & 0.441 & 0.421 \\
\hline 210577 & 2056 & 0.00 & 0.0 & 70.4 & 0.176 & 0.431 & 0.392 \\
\hline $2205 \quad 77$ & 1950 & 0.00 & 0.0 & 70.6 & 0.245 & 0.461 & 0.500 \\
\hline $16 \quad 0677$ & 1931 & 0.00 & 0.0 & 79.0 & 0.245 & 0.421 & 0.441 \\
\hline 190677 & 2250 & 0.00 & 0.0 & 183.3 & 0.255 & 0.568 & 0.588 \\
\hline $\begin{array}{lll}22 & 06 & 77\end{array}$ & 1556 & 0.00 & 0.0 & 73.0 & 0.235 & 0.421 & 0.421 \\
\hline $\begin{array}{lll}23 & 06 & 77\end{array}$ & 555 & 0.00 & 0.0 & 153.1 & 0.284 & 0.519 & 0.519 \\
\hline $24 \quad 06 \quad 77$ & 921 & 2.90 & 2.1 & 215.7 & 0.412 & 0.862 & 0.853 \\
\hline $24 \quad 06 \quad 77$ & 1543 & 0.00 & 0.0 & 213.5 & 0.333 & 0.637 & 0.647 \\
\hline 280677 & 2234 & 2.50 & 21.5 & 200.2 & 0.372 & 0.853 & 0.833 \\
\hline $2906 \quad 77$ & 953 & 3.50 & 21.8 & 238.6 & 0.451 & 0.951 & 0.941 \\
\hline $2906 \quad 77$ & 1510 & 6.00 & 91.6 & 238.5 & 0.559 & 1.088 & 1.019 \\
\hline $\begin{array}{lll}7 & 07 & 77\end{array}$ & 1209 & 0.00 & 0.0 & 145.2 & 0.274 & 0.529 & 0.549 \\
\hline $\begin{array}{lll}8 & 07 & 77\end{array}$ & 1954 & 4.60 & 46.0 & 225.2 & 0.480 & 0.882 & 0.862 \\
\hline 90777 & 54 & 11.20 & 127.2 & 235.6 & 0.647 & 1.186 & 1.156 \\
\hline 90777 & 1543 & 11.50 & 139.7 & 237.7 & 0.627 & 1.235 & 1.196 \\
\hline $\begin{array}{lll}11 & 07 & 77\end{array}$ & 1151 & 12.10 & 138.0 & 238.4 & 0.647 & 1.245 & 1.225 \\
\hline $\begin{array}{lll}13 & 07 & 77\end{array}$ & 1204 & 12.40 & 159.6 & 234.8 & 0.627 & 1.245 & 1.225 \\
\hline $\begin{array}{lll}15 & 07 & 77\end{array}$ & 1309 & 0.00 & 0.0 & 206.5 & 0.265 & 0.627 & 0.657 \\
\hline 10877 & 1046 & 12.00 & 160.1 & 234.6 & 0.745 & 1.303 & 1.372 \\
\hline $\begin{array}{lll}308 & 77\end{array}$ & 1020 & 12.30 & 162.8 & 233.9 & 0.774 & 1.343 & 1.421 \\
\hline $\begin{array}{lll}3 & 08 & 77\end{array}$ & 1420 & 0.00 & 0.0 & 216.1 & 0.392 & 0.706 & 0.784 \\
\hline $\begin{array}{lll}3 & 08 & 77\end{array}$ & 1816 & 1.50 & 9.1 & 211.6 & 0.431 & 0.804 & 0.872 \\
\hline $\begin{array}{lll}5 & 08 & 77\end{array}$ & 1428 & 0.00 & 0.0 & 215.1 & 0.392 & 0.696 & 0.794 \\
\hline $\begin{array}{lll}17 & 08 & 77\end{array}$ & 1415 & 12.10 & 158.6 & 234.0 & 0.872 & 1.382 & 1.509 \\
\hline $10 \quad 08 \quad 77$ & 1026 & 12.00 & 161.3 & 233.9 & 0.882 & 1.352 & 1.490 \\
\hline $\begin{array}{lll}22 & 08 & 77\end{array}$ & 1200 & 12.00 & 160.4 & 234.0 & 0.892 & 1.372 & 1.568 \\
\hline $\begin{array}{lll}22 & 08 & 77\end{array}$ & 1314 & 11.90 & 161.0 & 233.8 & 0.902 & 1.362 & 1.548 \\
\hline $\begin{array}{lll}22 & 08 & 77\end{array}$ & 1410 & 11.90 & 160.8 & 234.0 & 0.902 & 1.382 & 1.539 \\
\hline $2608 \quad 77$ & 954 & 12.00 & 164.2 & 234.0 & 0.931 & 1.392 & 1.588 \\
\hline $\begin{array}{lll}26 & 08 & 77\end{array}$ & 1607 & 2.50 & 42.9 & 220.6 & 0.706 & 0.970 & 1.147 \\
\hline $26 \quad 08 \quad 77$ & 1659 & 1.80 & 15.7 & 220.1 & 0.598 & 0.951 & 0.960 \\
\hline $14 \quad 1077$ & 1622 & 9.20 & 106.7 & 238.4 & 0.862 & 1.352 & 1.568 \\
\hline $15 \quad 1077$ & 1434 & 10.00 & 128.7 & 238 & 0.911 & 1.441 & 1.646 \\
\hline 161077 & 1443 & 11.80 & 138.4 & 238 & 21 & 1.460 & 1.676 \\
\hline $16 \quad 1077$ & 1508 & 11.90 & 133.8 & 238.1 & 0.666 & 1.156 & 1.480 \\
\hline $\begin{array}{lll}17 & 10 & 77\end{array}$ & 752 & 12.00 & 131.6 & 238.5 & 0.911 & 1.421 & 1.646 \\
\hline 171077 & 1449 & 4.00 & 25.0 & 233.4 & 0.617 & 0.941 & 1.127 \\
\hline 181077 & 1208 & 12.70 & 0.7 & 234.3 & 0.549 & 0.833 & 0.990 \\
\hline 191077 & 2038 & 3.90 & 16.6 & 237.8 & 0.598 & 0.931 & 1.098 \\
\hline $\begin{array}{lll}19 & 10 & 77\end{array}$ & 2101 & 0.00 & 6.3 & 236.8 & 0.480 & 0.725 & 0.911 \\
\hline $24 \quad 10 \quad 77$ & 937 & 11.40 & 109.2 & 238.6 & 382 & 1.372 & 1.597 \\
\hline 291077 & 13 & 10.70 & 118.8 & 239.0 & 302 & 1.392 & 1.646 \\
\hline $31 \quad 1077$ & 808 & 15.20 & 170.5 & & 41 & 1.519 & 1.784 \\
\hline $\begin{array}{lll}31 & 1077\end{array}$ & 2028 & 15.30 & 174.4 & .8 & 60 & 1.529 & 1.803 \\
\hline 11177 & 745 & 1.70 & 4.3 & 238.0 & 0.559 & 0.794 & 1.000 \\
\hline
\end{tabular}


TABLE 4. (contd)

\begin{tabular}{|c|c|c|c|c|c|c|c|}
\hline Date & Time & $\begin{array}{c}\text { Reactor } \\
\text { Power, } \\
\text { MW }\end{array}$ & $\begin{array}{l}\text { Assembly } \\
\text { Power, } \\
\mathrm{kW}\end{array}$ & $\begin{array}{l}\text { Moderator } \\
\text { Temperature, } \\
{ }^{\circ} \mathrm{C}\end{array}$ & Rod I & $\begin{array}{l}\text { essures, } \\
\text { Rod } 5\end{array}$ & $\frac{\mathrm{MPa}}{\mathrm{Rod} 6}$ \\
\hline $\begin{array}{lll}1 & 11 & 77\end{array}$ & 832 & 1.70 & 0.6 & 236.0 & 0.500 & 0.715 & 0.941 \\
\hline $\begin{array}{lll}4 & 11 & 77\end{array}$ & 853 & 1.6 & 3. & 237 & 0.529 & 0.764 & 0.970 \\
\hline 41177 & 902 & 1.70 & 3.2 & 237.7 & 0.529 & 0.784 & 0.970 \\
\hline 41177 & 911 & 1.70 & 3.3 & 237.3 & 0.529 & 0.794 & 0.970 \\
\hline 41177 & 919 & 1.60 & 3.6 & 237.1 & 0.539 & 0.784 & 0.980 \\
\hline 41177 & 926 & 1.60 & 3.7 & 237.2 & 0.529 & 0.794 & 0.980 \\
\hline 41177 & 934 & 1.70 & 3.7 & 237.2 & 0.539 & 0.784 & 0.980 \\
\hline 71277 & 1312 & 0.00 & 0.1 & 159.4 & 0.431 & 0.588 & 0.74 \\
\hline $\begin{array}{lll}7 & 12 & 77\end{array}$ & 2224 & 0.00 & 0.2 & 180.8 & 0.421 & 0.627 & 0.80 \\
\hline $\begin{array}{lll}10 & 12 & 77\end{array}$ & 831 & 2.40 & 5.7 & 238.7 & 0.559 & 0.804 & 0.911 \\
\hline $\begin{array}{lll}10 & 12 & 77\end{array}$ & 916 & 2.20 & 13.6 & 206.2 & 0.559 & 0.823 & 0.872 \\
\hline $10 \quad 12 \quad 77$ & 924 & 2.20 & 14.2 & 207.5 & 0.559 & 0.853 & 0.87 \\
\hline $\begin{array}{lll}11 & 12 & 77\end{array}$ & 2105 & 12.40 & 152.4 & 239.2 & 0.862 & 1.411 & 1.66 \\
\hline $\begin{array}{lll}13 & 12 & 77\end{array}$ & 2033 & 2.60 & 8.1 & 238.7 & 0.568 & 0.833 & 0.94 \\
\hline $\begin{array}{lll}13 & 12 & 77\end{array}$ & 2044 & 2.60 & 7.9 & 238.9 & 0.559 & 0.843 & 0.95 \\
\hline $\begin{array}{lll}13 & 12 & 77\end{array}$ & 2056 & 2.60 & 7.5 & 238.8 & 0.568 & 0.823 & 0.95 \\
\hline $\begin{array}{lll}16 & 12 & 77\end{array}$ & 904 & 2.50 & 5.9 & 238.2 & 0.549 & 0.794 & 0.92 \\
\hline $\begin{array}{lll}17 & 12 & 77\end{array}$ & 859 & 11.60 & 137.8 & 238.7 & 0.960 & 1.382 & 1.64 \\
\hline $\begin{array}{lll}21 & 12 & 77\end{array}$ & 1022 & 11.90 & 137.4 & 238 & 0.941 & 1.333 & \\
\hline $21 \quad 1277$ & 1220 & 11.90 & 137.4 & 238.6 & 0.960 & 1.372 & 1.646 \\
\hline $\begin{array}{lll}4 & 01 & 78\end{array}$ & 1013 & 11.30 & 156.3 & 238.9 & 0.951 & 1.372 & 1.73 \\
\hline $\begin{array}{lll}5 & 0178\end{array}$ & 935 & 11.20 & 155.8 & 238.7 & 0.882 & 1.372 & 1.71 \\
\hline $\begin{array}{lll}50178 & \end{array}$ & 954 & 11.30 & 155.8 & 238.8 & 0.970 & 1.382 & 1.7 \\
\hline 50178 & 1050 & 11.30 & 153.8 & 238.8 & 0.970 & 1.372 & 1.72 \\
\hline 50178 & 1117 & 11.40 & 153.5 & 230.0 & 0.970 & 1.382 & 1.72 \\
\hline 50178 & 1151 & 11.40 & 153.7 & 23 & 0.970 & $1.39 ?$ & 1.72 \\
\hline $\begin{array}{lll}501 & 78\end{array}$ & 1211 & 11.30 & 153.7 & 23 & 0.872 & 1. & 1.72 \\
\hline $\begin{array}{lll}501 & 78\end{array}$ & 1224 & 11.20 & 153.5 & 23 & 0.970 & 1. & 1.7 \\
\hline 70178 & 931 & 11.60 & 155.6 & 23 & 0.872 & 1.372 & 1.72 \\
\hline 110178 & 848 & 1.50 & 7.3 & & 0.578 & 0.823 & 0.970 \\
\hline $\begin{array}{lll}12 & 01 & 78\end{array}$ & 1313 & 11.60 & 158.0 & 239.4 & 0.882 & 1.372 & 1.75 \\
\hline $\begin{array}{lll}12 & 01 & 78\end{array}$ & 1331 & 11.40 & 154.6 & & 0.882 & & 1.74 \\
\hline 130178 & 1452 & 1.70 & 8.5 & 23 & 0.568 & 0.861 & 1.000 \\
\hline 130178 & 150 & 1.70 & 8.5 & 23 & 0.568 & 0.843 & 1.000 \\
\hline $\begin{array}{lll}7 & 07 & 78\end{array}$ & 1630 & 0.00 & 0.4 & 72.4 & 0.402 & 0.490 & 0.608 \\
\hline $707 \quad 78$ & 1638 & 0.0 & 0.3 & 72.4 & 0.372 & 0.490 & 0.58 \\
\hline $\begin{array}{lll}7 & 07\end{array}$ & 164 & 0.1 & 0.3 & 72 & 0.372 & & 0.59 \\
\hline $\begin{array}{lll}707 & 78\end{array}$ & 1651 & 0.00 & 0.3 & 72.4 & 0.372 & 0.470 & 0.617 \\
\hline $\begin{array}{lll}10 & 07 & 78\end{array}$ & 911 & 0. & 0.2 & 200.2 & 0.557 & 0.706 & 0.931 \\
\hline $\begin{array}{lll}10 & 07 & 78\end{array}$ & 918 & 0.0 & 0.1 & & 0.578 & 0.7 & 0.931 \\
\hline $\begin{array}{lll}10 & 07 & 78\end{array}$ & 924 & 0.00 & 0.2 & 200 & 0.578 & 0.725 & 0.931 \\
\hline $\begin{array}{lll}10 & 07 & 78\end{array}$ & 931 & 0.00 & 0.1 & 200.3 & 0.568 & 0.813 & 0.90 \\
\hline $\begin{array}{lll}10 & 07 & 78\end{array}$ & 938 & 0.00 & 0.2 & 200.1 & 0.568 & 0.706 & 0.931 \\
\hline $\begin{array}{lll}10 & 07 & 78\end{array}$ & 2032 & 2.1 & 5.0 & & 0.647 & & 1.117 \\
\hline $\begin{array}{lll}10 & 07 & 78\end{array}$ & 2030 & 2.10 & 4.8 & 239.5 & 0.617 & 0.843 & 1.049 \\
\hline $\begin{array}{lll}10 & 07 & 78\end{array}$ & 2039 & 2.10 & 5.2 & 239.4 & 0.608 & 0.833 & 1.049 \\
\hline
\end{tabular}


TABLE 4. (contd)

\begin{tabular}{|c|c|c|c|c|c|c|c|}
\hline Date & Time & $\begin{array}{l}\text { Reactor } \\
\text { Power, } \\
\text { MW }\end{array}$ & $\begin{array}{l}\text { Assemb ly } \\
\text { Power, } \\
\mathrm{kW}\end{array}$ & $\begin{array}{l}\text { Moderator } \\
\text { Temperature, } \\
{ }^{\circ} \mathrm{C}\end{array}$ & Rod & $\begin{array}{l}\text { essures } \\
\text { Rod } 5\end{array}$ & $\frac{\mathrm{MPa}}{\text { Rod } 6}$ \\
\hline $07 \quad 78$ & 2050 & 2.00 & 5.1 & 239.1 & 0.617 & 0.872 & 1.049 \\
\hline $\begin{array}{lll}13 & 07 & 78\end{array}$ & 1250 & 3.30 & 11.8 & 239.9 & 0.706 & 0.960 & 1.235 \\
\hline 130778 & 1324 & 4.30 & 22.2 & 238.4 & 0.784 & 1.068 & 1.372 \\
\hline $1307 \quad 78$ & 1407 & 6.20 & 36.2 & 239.4 & 0.892 & 1.205 & 1.529 \\
\hline $\begin{array}{lll}13 & 07 & 78\end{array}$ & 1430 & 7.20 & 43.0 & 239.2 & 0.960 & 1.254 & 1 \\
\hline $\begin{array}{lll}13 & 07 & 78\end{array}$ & 1457 & 8.20 & 49.6 & 238.5 & 0.951 & 1.294 & 1.63 ? \\
\hline $1307 \quad 78$ & 1511 & 8.70 & 52.3 & 238.9 & 0.970 & 1.313 & 1.676 \\
\hline $1307 \quad 78$ & 1531 & 9.40 & 56.9 & 239.0 & 0.970 & 1.382 & 1.695 \\
\hline $1307 \quad 78$ & 1558 & 10.30 & 63.7 & 238. & 1.000 & 1.372 & 1.754 \\
\hline $\begin{array}{lll}13 & 07 & 78\end{array}$ & 1619 & 11.00 & 71.1 & 239.4 & 1.029 & 1.421 & 1.793 \\
\hline $\begin{array}{lll}13 & 07 & 78\end{array}$ & 1640 & 11.90 & 78.1 & 239.5 & 1.049 & 1.460 & 1.842 \\
\hline $\begin{array}{lll}24 & 07 & 78\end{array}$ & 945 & 12.30 & 83.1 & 239.9 & 1.049 & 1.490 & 1.852 \\
\hline $\begin{array}{lll}1 & 08 & 78\end{array}$ & 1355 & 12.50 & 87.4 & 235.5 & 1.058 & 1.509 & 1.89 \\
\hline $\begin{array}{lll}4 & 08 & 78\end{array}$ & 1450 & 12.70 & 88.8 & 235.7 & 0.980 & 1.519 & 1.89 \\
\hline $\begin{array}{lll}4 & 08 & 78\end{array}$ & 1505 & 12.70 & 88.5 & 235.8 & 1.078 & 1.519 & 1.911 \\
\hline $\begin{array}{lll}4 & 08 & 78\end{array}$ & 1512 & 12.70 & 88.3 & 235.8 & 1.058 & 1.529 & 1.911 \\
\hline $\begin{array}{lll}7 & 08 & 78\end{array}$ & 1822 & 12.30 & 97.0 & 235.7 & 1.088 & 1.519 & 1.950 \\
\hline $\begin{array}{l}70878 \\
\end{array}$ & 1829 & 12.40 & 96.8 & 235.9 & 1.078 & 1.539 & -- \\
\hline $\begin{array}{lll}9 & 08 & 78\end{array}$ & 747 & 2.00 & 5.5 & 239.7 & 0.598 & 0.833 & 1.186 \\
\hline 90878 & 755 & 2.00 & 4.5 & 239.5 & 0.627 & 0.833 & 1.127 \\
\hline 90878 & 1059 & 1.50 & 0.2 & 229.9 & 0.559 & 0.745 & 1.09 \\
\hline $14 \quad 0878$ & 1107 & 12.60 & 100.9 & 235.0 & 1.117 & 1.597 & 1.99 \\
\hline $1408 \quad 78$ & 1115 & 12.60 & 100.6 & 235.0 & 1.156 & 1.588 & 1.98 \\
\hline 150878 & 1440 & 5.20 & 44.7 & 235.3 & 0.921 & 1.294 & 1.66 \\
\hline $\begin{array}{lll}22 & 08 & 78\end{array}$ & 1634 & 3.90 & 48.7 & 234.9 & 0.951 & 1.303 & 1.68 \\
\hline $\begin{array}{lll}22 & 08 & 78\end{array}$ & 1650 & 4.70 & 50.3 & 235.2 & 0.960 & 1.333 & 1.715 \\
\hline $\begin{array}{lll}22 & 08 & 78\end{array}$ & 1706 & 6.30 & 56.2 & 235.3 & 1.019 & 1.372 & 1.784 \\
\hline 280878 & 746 & 12.30 & 101.7 & 23 & 1.254 & 1.5 & 2.01 \\
\hline 280878 & 758 & 12.40 & 101.6 & 233.5 & 1.147 & 1.578 & 2.01 \\
\hline $\begin{array}{lll}31 & 08 & 78\end{array}$ & 751 & 12.60 & 100.3 & & 1.176 & 1.568 & 2.03 \\
\hline 30978 & 2119 & 12.20 & 99.7 & 235.1 & 1.186 & 1.568 & 2.048 \\
\hline 30978 & 2138 & 12.10 & 99.7 & 235 & 1.186 & 1.558 & 2.048 \\
\hline 30978 & 2144 & 12.20 & 99.8 & 235.3 & 1.176 & 1.539 & 2.019 \\
\hline 40978 & 743 & 1.70 & 4.1 & 234.6 & 0.676 & 0.843 & 1.147 \\
\hline 40978 & 750 & 1.70 & 3.1 & 236 & 0.696 & 0.8 & 1.147 \\
\hline 80978 & 1048 & 12.40 & 96.8 & 235.5 & 1.186 & 1.558 & 1.99 \\
\hline 130978 & 759 & 11.20 & 98.3 & 235.0 & 1.196 & 1.548 & 1.98 \\
\hline 130978 & 808 & 11.60 & 98.3 & 234.9 & 1.196 & 1.558 & 2.00 \\
\hline $\begin{array}{lll}15 & 09 & 78\end{array}$ & 753 & 11.90 & 99.7 & 235.1 & 1.196 & 1.558 & 1.99 \\
\hline 200978 & 758 & 11.80 & 100.9 & 235.2 & 1.196 & 1.519 & 1.999 \\
\hline 200978 & 808 & 11.80 & 100.9 & 234.9 & 1.205 & 1.539 & 1.99 \\
\hline $25 \quad 0978$ & 755 & 11.70 & 101.0 & 235.0 & 1.215 & 1.539 & 1.96 \\
\hline $26 \quad 0978$ & 92 & 1.30 & 0.4 & 227.4 & 0.676 & 0.784 & 1.03 \\
\hline 260978 & 930 & 1.30 & 0.4 & 227.8 & 0.666 & 0.833 & 1.03 \\
\hline 31078 & 749 & 11.90 & 90.0 & 235.2 & 1.225 & 1.539 & 2.058 \\
\hline 10 & 756 & 11.90 & 90.0 & 235.3 & 1.235 & 1.548 & 2.038 \\
\hline
\end{tabular}


IABLE 4. (contd)

\begin{tabular}{|c|c|c|c|c|c|c|c|}
\hline & & Power, & Power, & Temperature, & & essures & $\mathrm{MPa}$ \\
\hline Date & Time & & & & Rod I & Rod 5 & \\
\hline $5 \quad 1078$ & 803 & 10.50 & 96.5 & 235.1 & 1.254 & 1.597 & 2.058 \\
\hline $23 \quad 1178$ & 1636 & 0.00 & & 71.7 & 0.529 & 0.598 & 0.725 \\
\hline 231178 & 1649 & 0.00 & 0.0 & 72.1 & 0.529 & 0.627 & 0.725 \\
\hline $27 \mathrm{il} 78$ & 838 & 2.70 & 7.1 & 239.5 & 0.637 & 0.755 & 0.784 \\
\hline $27 \quad 1178$ & 1244 & 2.80 & 7.0 & 238.7 & 0.794 & 0.715 & 0.921 \\
\hline 281178 & 745 & 2.60 & 6.0 & 238.8 & 0.902 & 0.833 & 1.117 \\
\hline $28 \quad 1178$ & 2056 & 8.90 & 65.9 & 239.9 & 1.186 & 1.480 & 1.891 \\
\hline 30 il 78 & 1027 & 13.10 & 89.0 & 240.2 & 1.264 & 1.597 & 1.960 \\
\hline $\begin{array}{lll}30 & 11 & 78\end{array}$ & 1115 & 13.30 & 90.8 & 240.3 & 1.313 & 1.656 & 2.038 \\
\hline $\begin{array}{lll}30 & 11 & 78\end{array}$ & 1404 & 13.00 & 89.6 & 240.4 & 1.264 & 1.646 & 2.029 \\
\hline $\begin{array}{lll}31278 & \end{array}$ & 1020 & 6.10 & 37.8 & 238.1 & 1.009 & 1.254 & 1.57 \\
\hline 41278 & 1029 & 13.60 & 96.1 & 240.3 & 1.284 & 1.656 & 2.07 \\
\hline $\begin{array}{lll}712 & 78\end{array}$ & 745 & 2.20 & 5.7 & 239.9 & 0.872 & 0.833 & 1.117 \\
\hline 91278 & 1719 & 13.00 & 90.5 & 239.9 & 1.264 & 1.607 & 2.019 \\
\hline $14 \quad 1278$ & 754 & 1.70 & 4.4 & 239.5 & 0.862 & 0.833 & .127 \\
\hline 181278 & 750 & 1.60 & 4.3 & 239.2 & 0.882 & 0.843 & 1.147 \\
\hline $\begin{array}{lll}20 & 12 & 78\end{array}$ & 745 & 1.60 & 4.8 & 238.9 & 0.882 & 0.960 & .147 \\
\hline $\begin{array}{lll}21 & 12 & 78\end{array}$ & 805 & 12.20 & 78.4 & 240.3 & 1.264 & 1.607 & 2.038 \\
\hline 20179 & 810 & 12.30 & 80.4 & 239.6 & -. & 1.548 & 1.96 \\
\hline 30179 & 920 & 11.90 & 89.5 & 240.1 & 1.264 & 1.607 & 2.097 \\
\hline 30179 & 939 & 12.10 & 89.6 & 240.3 & 1.264 & 1.607 & 2.097 \\
\hline 30179 & 953 & 12.00 & 89.4 & 240.3 & 1.284 & 1.617 & 2.107 \\
\hline 30179 & 1008 & 12.00 & 89.5 & 240.3 & 1.274 & 1.607 & 2.097 \\
\hline 30179 & 1021 & 11.90 & 89.4 & 240.0 & 1. 284 & 1.627 & 2.097 \\
\hline 30179 & 1049 & 12.00 & 89.6 & 240.0 & 1.284 & 1.617 & 2.087 \\
\hline 30179 & 1131 & 12.10 & 89.5 & 240.3 & 1.284 & 1.627 & 2.097 \\
\hline 30179 & 1203 & 11.90 & 89.6 & 239.9 & 1.284 & 1.607 & 2.097 \\
\hline $\begin{array}{lll}3 & 0179\end{array}$ & 1247 & 12.00 & 89.8 & 240.3 & 1.284 & 1.627 & 2.087 \\
\hline 30179 & 1308 & 12.00 & 89.7 & 239.9 & 1.284 & 1.617 & 2.097 \\
\hline $\begin{array}{lll}301 & 79\end{array}$ & 1318 & 12.00 & 89.7 & 240.0 & 1.294 & 1.637 & 2.097 \\
\hline 30179 & 1418 & 12.00 & 89.6 & 240.3 & 1.274 & 1.617 & 2.097 \\
\hline 30179 & 1436 & 12.00 & 89.7 & 240 & 1.284 & 1.617 & 2.097 \\
\hline $\begin{array}{lll}4 & 01 & 79\end{array}$ & 845 & 1.60 & 4.9 & 239.1 & 0.862 & 0.804 & 1.166 \\
\hline 40179 & 944 & 1.50 & 4.0 & 238.6 & 0.882 & 0.833 & 1.205 \\
\hline $\begin{array}{lll}5 & 01 & 79\end{array}$ & 1647 & 9.50 & 74.4 & 239.5 & 1.205 & 1.519 & $\begin{array}{l}1.999 \\
1.90\end{array}$ \\
\hline $\begin{array}{lll}5 & 01 & 79\end{array}$ & 1647 & 9.50 & 74.4 & 239.5 & 1.205 & 1.519 & 1.999 \\
\hline 150179 & 755 & 1.30 & 6.0 & 239.4 & 0.902 & 0.804 & 0.794 \\
\hline $\begin{array}{lll}16 & 01 & 79\end{array}$ & 2015 & 7.50 & 57.6 & 240.1 & 1.098 & 1.372 & - \\
\hline 90179 & 755 & 11.90 & 93.9 & 239.5 & 1.264 & 1.607 & $\ldots$ \\
\hline $22 \quad 01 \quad 79$ & 75 & 1.50 & 6.1 & 239.2 & 0.902 & 0.853 &.- \\
\hline $\begin{array}{lll}25 & 01 & 79\end{array}$ & 756 & 12.00 & 92.9 & 240.1 & 1.284 & 1.607 & - \\
\hline 20479 & 827 & 2.20 & 5.0 & 238.9 & 0.970 & 0.931 & $\ldots$ \\
\hline 20479 & 84 & 2.30 & 5.2 & 238.8 & 0.843 & 0.970 &.- \\
\hline $\begin{array}{lll}6 & 04 & 79\end{array}$ & 75 & 10.70 & 97.0 & 239.4 & 1.401 & 1.774 & \\
\hline $\begin{array}{lll}7 & 04 & 79\end{array}$ & 821 & 2.60 & 16.2 & 238.9 & 0.862 & 1.049 & $\ldots$ \\
\hline 70479 & 1253 & 11.10 & 99.4 & 239.6 & 1.421 & 1.774 & \\
\hline
\end{tabular}


TABLE 4. (contd)

\begin{tabular}{|c|c|c|c|c|c|c|c|}
\hline Date & Time & $\begin{array}{l}\text { Reactor } \\
\text { Power, } \\
\text { MW } \\
\end{array}$ & $\begin{array}{c}\text { Assembly } \\
\text { Power, } \\
\mathrm{KWH}\end{array}$ & $\begin{array}{l}\text { Moderator } \\
\text { Temperature, } \\
\text { oc }\end{array}$ & Rod & $\begin{array}{l}\text { essures } \\
\text { Rod } 5\end{array}$ & $\begin{array}{l}\text { MPa } \\
\text { Rod } 6\end{array}$ \\
\hline 0479 & 746 & 11.10 & 97.8 & 235.0 & 1.352 & 1.666 & $\cdots$ \\
\hline 0479 & 1553 & 2.20 & 9. & 229.7 & 0.794 & 0.902 & \\
\hline $22 \quad 04 \quad 79$ & 1811 & 10.80 & 95.7 & 230.0 & 1.352 & 1.637 & - \\
\hline $\begin{array}{lll}26 & 04 & 79\end{array}$ & 756 & 10.70 & 94.8 & 229.8 & 1.343 & 1.617 & - \\
\hline $\begin{array}{lll}27 & 04 & 79\end{array}$ & 858 & 10.60 & 95.8 & 230.6 & 1.411 & 1.695 & $\cdots$ \\
\hline $27 \quad 04 \quad 79$ & 0 & 10.50 & 95.6 & 230.3 & 0.098 & 0.098 & 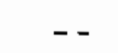 \\
\hline $27 \quad 04 \quad 79$ & 931 & 10.50 & 95.6 & 230.3 & 1.421 & 1.695 & -. \\
\hline $\begin{array}{lll}27 & 04 & 79\end{array}$ & 1208 & 10.50 & 95.1 & 230.4 & 1.411 & 1.666 & 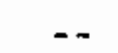 \\
\hline $\begin{array}{lll}30 & 04 & 79\end{array}$ & 754 & 10.70 & 97.4 & 229.9 & 1.431 & 1.686 & - \\
\hline $\begin{array}{lll}30 & 04 & 79\end{array}$ & 0 & 10.70 & 96.5 & 230.1 & 0.098 & 0.098 & - \\
\hline $\begin{array}{lll}30 & 04 & 79\end{array}$ & 1057 & 10.50 & 96.4 & 229.7 & 1.431 & 1.686 & -- \\
\hline 40579 & 746 & 1.40 & 16.2 & 229.5 & 0.911 & 1.009 & $\cdots$ \\
\hline $\begin{array}{lll}11 & 05 & 79\end{array}$ & 753 & 9.60 & 92.7 & 230.1 & 1.431 & 1.646 & -- \\
\hline $\begin{array}{lll}11 & 0579\end{array}$ & 1025 & 4.80 & 51.1 & 229.8 & 1.225 & 1.392 & -- \\
\hline $\begin{array}{lll}15 & 05 & 79\end{array}$ & 802 & 0.00 & 1.0 & 71.1 & 0.608 & 0.527 & -. \\
\hline $2105 \quad 79$ & 800 & 4.30 & 41.9 & 224.2 & 1.166 & 1.294 & .- \\
\hline $\begin{array}{lll}27 & 05 & 79\end{array}$ & 1043 & 0.00 & 1.1 & 74.2 & 0.412 & 0.431 & ـ- \\
\hline $\begin{array}{lll}9 & 07 & 79\end{array}$ & 1831 & 2.60 & 16.8 & 237.1 & 1.117 & 1.235 & -- \\
\hline $\begin{array}{lll}10 & 07 & 79\end{array}$ & 635 & 2.20 & 14.3 & 239.6 & 1.078 & 1.196 & -- \\
\hline $\begin{array}{lll}13 & 07 & 79\end{array}$ & 1400 & 10.10 & 88.1 & 238.9 & 1.656 & 1.921 & \\
\hline $\begin{array}{lll}15 & 07 & 79\end{array}$ & 1322 & 11.00 & 94.4 & 238.6 & 1.686 & 1.950 & - \\
\hline $\begin{array}{llll}16 & 07 & 79\end{array}$ & 806 & 1.70 & 12.5 & 238.9 & 1.058 & 1.176 &. \\
\hline $\begin{array}{lll}16 & 07 & 79\end{array}$ & 1934 & 12.10 & 101.3 & 239.3 & 1.695 & 1.980 & $\cdots$ \\
\hline $\begin{array}{lll}25 & 07 & 79\end{array}$ & 1242 & 1.70 & 13.0 & 238.7 & 1.000 & 1.107 & - \\
\hline $\begin{array}{llll}26 & 07 & 79\end{array}$ & 750 & 11.80 & 97.2 & 239.4 & 1.695 & 1.960 & -- \\
\hline 20879 & 814 & 11.40 & 102.5 & 225.0 & 1.627 & 1.891 & -- \\
\hline $\begin{array}{lll}7 & 08 & 79\end{array}$ & 748 & 11.40 & 100.3 & 225.3 & 1.627 & 1.862 & \\
\hline $\begin{array}{lll}10 & 08 & 79\end{array}$ & 754 & 11.70 & 100.5 & 234 & 1.666 & 1.931 & -- \\
\hline $\begin{array}{lll}15 & 08 & 79\end{array}$ & 925 & 11.30 & 97.0 & 234.8 & 1.666 & 1.882 & - \\
\hline $\begin{array}{lll}21 & 08 & 79\end{array}$ & 758 & 7.60 & 68.4 & 23 & 1.568 & 1.764 & -- \\
\hline $\begin{array}{lll}23 & 08 & 79\end{array}$ & 1433 & 11.80 & 97.9 & 235.7 & 1.637 & 1.940 & - \\
\hline $\begin{array}{lll}23 & 08 & 79\end{array}$ & 1448 & 11.60 & 97.8 & 235 & 1.646 & 1.931 & -- \\
\hline $\begin{array}{lll}23 & 08 & 79\end{array}$ & 1525 & 1.40 & 2.2 & 222.7 & 0.657 & 0.735 & -. \\
\hline $\begin{array}{lll}24 & 08 & 79\end{array}$ & 1225 & 1.90 & 5.4 & 233.8 & 0.960 & 1.058 & \\
\hline $\begin{array}{lll}5 & 10 & 79\end{array}$ & 1623 & 11.80 & 97.7 & 239.6 & 1.470 & 1.911 & -- \\
\hline $\begin{array}{lll}5 & 1070\end{array}$ & 1750 & 11.80 & 98.2 & 239.9 & 1.568 & 1.940 & -- \\
\hline $10 \quad 1079$ & 933 & 8.40 & 66.8 & 239.8 & 1.421 & 1. & -. \\
\hline $\begin{array}{lll}12 & 10 & 79\end{array}$ & 82 & 2.20 & 5.6 & 238.7 & 0.911 & 1.078 & \\
\hline $18 \quad 10 \quad 79$ & 6 & 11.90 & 99.7 & 239.9 & 1.548 & 1.989 & -- \\
\hline $25 \quad 1079$ & 835 & 12.40 & 98.9 & 239.9 & 1.617 & 2.009 & 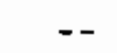 \\
\hline $\begin{array}{lll}25 & 10 & 79\end{array}$ & 1220 & 12. & 99 & 239 & 1.617 & 2.029 & 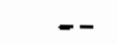 \\
\hline $\begin{array}{lll}26 & 10 & 79\end{array}$ & 1010 & 12.30 & 99.2 & 239.7 & 1.617 & 2.009 & -- \\
\hline $\begin{array}{lll}2 & 11 & 79\end{array}$ & 1203 & 12.40 & 99.2 & 239.8 & 1.588 & 1.989 & -- \\
\hline 81179 & 815 & 12.1 & 99.9 & 239.5 & 1.607 & 1.980 & - \\
\hline 241179 & 859 & 11.80 & 97.9 & 239.3 & 1.568 & 2.019 & -. \\
\hline $\begin{array}{lll}30 & 11 & 79\end{array}$ & 1821 & 12.20 & 99.8 & 239.8 & 1.519 & 1.950 & -- \\
\hline
\end{tabular}


IABLE 4. (contd)

\begin{tabular}{|c|c|c|c|c|c|c|c|}
\hline Date & Tine & $\begin{array}{l}\text { Reactor } \\
\text { Power, } \\
\text { Mw }\end{array}$ & $\begin{array}{l}\text { Assemb ly } \\
\text { Power, } \\
\mathrm{kW} \\
\end{array}$ & $\begin{array}{l}\text { Moderator } \\
\text { Temperature, } \\
{ }^{\circ} \mathrm{C}\end{array}$ & \multicolumn{3}{|c|}{ Pressures, MPa } \\
\hline 101279 & 929 & 0.00 & 0.4 & 205.8 & 0.902 & 0.813 & - \\
\hline 131279 & 816 & 2.60 & 5.9 & 239.8 & 0.853 & 1.058 & -- \\
\hline 161279 & 1930 & 11.60 & 92.9 & 239.2 & 1.539 & 1.931 & -- \\
\hline 191279 & 1229 & 4.50 & 33.1 & 210.1 & 1.088 & 1.362 & $=$ \\
\hline 231279 & 1805 & 12.10 & 96.5 & 239.7 & 1.539 & 2.009 & -- \\
\hline 271279 & 325 & 12.20 & 98.4 & 239.4 & 1.548 & 2.087 & - \\
\hline 20180 & 2121 & 12.10 & 98.5 & 239.2 & 1.529 & 1.960 & -- \\
\hline 140380 & 1826 & 0.00 & 0.5 & 84.4 & 0.666 & 0.951 & $\cdots$ \\
\hline 160380 & 1834 & 0.70 & 6.2 & 239.6 & 0.755 & 1.274 & - \\
\hline 160380 & 2054 & 0.00 & 0.3 & 228.3 & 0.833 & 1.068 & - \\
\hline $\begin{array}{lll}28 & 03 & 80\end{array}$ & 1405 & 11.50 & 83.9 & 240.0 & 1.470 & 2.323 & - \\
\hline 20480 & 1037 & 10.20 & 76.5 & 239.4 & 1.499 & 2.362 & -- \\
\hline 50480 & 2159 & 10.40 & 77.0 & 239.3 & 1.480 & 2.303 & - \\
\hline $1004 \quad 80$ & 2055 & 13.10 & 98.6 & 240.0 & 1.529 & 2.411 & -- \\
\hline 130480 & 957 & 13.20 & 88.2 & 240.0 & 1.470 & 2.293 & - \\
\hline $1604 \quad 80$ & 923 & 13.40 & 88.6 & 239.7 & 1.499 & 2.303 & -- \\
\hline $\begin{array}{lll}25 & 04 & 80\end{array}$ & 1835 & 0.10 & 0.8 & 74.2 & 0.412 & 0.892 & - \\
\hline $2704 \quad 80$ & 927 & 1.70 & 4.0 & 234.4 & 0.804 & 1.274 & - \\
\hline $\begin{array}{lll}30 & 04 & 80\end{array}$ & 806 & 8.00 & 47.8 & 234.7 & 1.274 & 1.960 & -- \\
\hline $\begin{array}{lll}5 & 05 & 80\end{array}$ & 1207 & 12.20 & 81.8 & 234.7 & 1.441 & -- & -- \\
\hline $\begin{array}{lll}5 & 05 & 30\end{array}$ & 2121 & 12.10 & 81.3 & 234.9 & 1.480 & 2.313 & $\ldots$ \\
\hline 80580 & 1835 & 9.40 & 62.4 & 229.4 & 1.411 & 2.156 & $\ldots$ \\
\hline 90580 & 1027 & 2.00 & 3.4 & 229.7 & 0.960 & 1.235 & -- \\
\hline 180580 & 1840 & 1.80 & 3.3 & 210.4 & 0.843 & 1.078 & -- \\
\hline
\end{tabular}


BURNUP

Calculated burnups at each TC location for each rod are presented in Table 5. These are the local burnups at the end of each month of operation and were calculated by numerically integrating the depletion-corrected power history over time. There was good agreement between these results using this method and PIE data from rod 6 of IFA-431 (Nealley et al. 1979).

TABLE 5. Burnup in GJ/kgu(a)

\begin{tabular}{|c|c|c|c|c|c|c|c|}
\hline onth-Year & Location & Rod 1 & Rod 2 & Rod 3 & Rod 8 & Rod 5 & Rod 6 \\
\hline $1-78$ & $\begin{array}{l}\text { UTC }(b) \\
\text { LTC }(c)\end{array}$ & $\begin{array}{l}1456.1 \\
1044.9\end{array}$ & $\begin{array}{l}1393.8 \\
1024.5\end{array}$ & $\begin{array}{l}1408.1 \\
1047.1\end{array}$ & $\begin{array}{r}1186.1 \\
877.9\end{array}$ & $\begin{array}{l}1484.2 \\
1091.0\end{array}$ & $\begin{array}{l}1481.7 \\
1077.3\end{array}$ \\
\hline $4-78$ & $\begin{array}{l}\text { UTC } \\
\text { LTC }\end{array}$ & $\begin{array}{l}1471.6 \\
1056.6\end{array}$ & $\begin{array}{l}1409.0 \\
1035.9\end{array}$ & $\begin{array}{l}1422.8 \\
1058.4\end{array}$ & $\begin{array}{r}1200.4 \\
889.1\end{array}$ & $\begin{array}{l}1499.0 \\
1102.7\end{array}$ & $\begin{array}{l}1497.1 \\
1089.2\end{array}$ \\
\hline $5-78$ & $\begin{array}{l}\text { UTC } \\
\text { LTC }\end{array}$ & $\begin{array}{l}1515.0 \\
1088.8\end{array}$ & $\begin{array}{l}1451.2 \\
1067.4\end{array}$ & $\begin{array}{l}1464.3 \\
1090.3\end{array}$ & $\begin{array}{r}1241.5 \\
921.4\end{array}$ & $\begin{array}{l}1541.4 \\
1135.9\end{array}$ & $\begin{array}{l}1540.5 \\
1122.2\end{array}$ \\
\hline $6-78$ & $\begin{array}{l}\text { UTC } \\
\text { LTC }\end{array}$ & $\begin{array}{l}1556.1 \\
1118.4\end{array}$ & $\begin{array}{l}1491.1 \\
1096.3\end{array}$ & $\begin{array}{l}1503.6 \\
1119.6\end{array}$ & $\begin{array}{r}1280.7 \\
951.0\end{array}$ & $\begin{array}{l}1581.9 \\
1166.4\end{array}$ & $\begin{array}{l}1582.0 \\
1152.5\end{array}$ \\
\hline $7-78$ & $\begin{array}{l}\text { UTC } \\
\text { LTC }\end{array}$ & $\begin{array}{l}1596.2 \\
1149.0\end{array}$ & $\begin{array}{l}1530.7 \\
1126.3\end{array}$ & $\begin{array}{l}1543.2 \\
1150.1\end{array}$ & $\begin{array}{r}1319.9 \\
981.7\end{array}$ & $\begin{array}{l}1621.8 \\
1198.0\end{array}$ & $\begin{array}{l}1622.2 \\
1183.9\end{array}$ \\
\hline $8-78$ & $\begin{array}{l}\text { UTC } \\
\text { LTC }\end{array}$ & $\begin{array}{l}1699.8 \\
1224.8\end{array}$ & $\begin{array}{l}1631.8 \\
1200.4\end{array}$ & $\begin{array}{l}1643.4 \\
1225.1\end{array}$ & $\begin{array}{l}1420.1 \\
1057.4\end{array}$ & $\begin{array}{l}1724.9 \\
1276.0\end{array}$ & $\begin{array}{l}1727.0 \\
1261.6\end{array}$ \\
\hline $9-78$ & $\begin{array}{l}\text { UTC } \\
\text { LTC }\end{array}$ & $\begin{array}{l}1803.1 \\
1299.4\end{array}$ & $\begin{array}{l}1731.7 \\
1273.4\end{array}$ & $\begin{array}{l}1741.8 \\
1298.3\end{array}$ & $\begin{array}{l}1518.6 \\
1130.7\end{array}$ & $\begin{array}{l}1827.2 \\
1351.6\end{array}$ & $\begin{array}{l}1831.5 \\
1337.5\end{array}$ \\
\hline $10-78$ & $\begin{array}{l}\text { UTC } \\
\text { LTC }\end{array}$ & $\begin{array}{l}1818.8 \\
1310.4\end{array}$ & $\begin{array}{l}1746.9 \\
1284.0\end{array}$ & $\begin{array}{l}1756.8 \\
1309.1\end{array}$ & $\begin{array}{l}1533.7 \\
1141.5\end{array}$ & $\begin{array}{l}1842.7 \\
1362.7\end{array}$ & $\begin{array}{l}1847.4 \\
1348.7\end{array}$ \\
\hline $11-78$ & $\begin{array}{l}\text { UTC } \\
\text { LTC }\end{array}$ & $\begin{array}{l}1825.1 \\
1315.7\end{array}$ & $\begin{array}{l}1753.3 \\
1289.3\end{array}$ & $\begin{array}{l}1763.1 \\
1314.4\end{array}$ & $\begin{array}{l}1540.0 \\
1146.9\end{array}$ & $\begin{array}{l}1849.0 \\
1368.2\end{array}$ & $\begin{array}{l}1853.7 \\
1354.1\end{array}$ \\
\hline $12-78$ & $\begin{array}{l}\text { UTC } \\
\text { LTC }\end{array}$ & $\begin{array}{l}1890.7 \\
1368.3\end{array}$ & $\begin{array}{l}1818.2 \\
1340.8\end{array}$ & $\begin{array}{l}1828.0 \\
1366.5\end{array}$ & $\begin{array}{l}1606.2 \\
1200.4\end{array}$ & $\begin{array}{l}1914.7 \\
1422.2\end{array}$ & $\begin{array}{l}1919.8 \\
1407.9\end{array}$ \\
\hline $1-79$ & $\begin{array}{l}\text { UTC } \\
\text { LTC }\end{array}$ & $\begin{array}{l}1933.3 \\
1400.5\end{array}$ & $\begin{array}{l}1859.8 \\
1372.4\end{array}$ & $\begin{array}{l}1869.2 \\
1398.6\end{array}$ & $\begin{array}{l}1648.4 \\
1233.2\end{array}$ & $\begin{array}{l}1957.2 \\
1455.4\end{array}$ & $\begin{array}{l}1963.0 \\
1440.9\end{array}$ \\
\hline $4-79$ & $\begin{array}{l}\text { UTC } \\
\text { LTC }\end{array}$ & $\begin{array}{l}2015.4 \\
1465.8\end{array}$ & $\begin{array}{l}1940.1 \\
1437.5\end{array}$ & $\begin{array}{l}1948.4 \\
1465.0\end{array}$ & $\begin{array}{l}1727.0 \\
1299.6\end{array}$ & $\begin{array}{l}2037.9 \\
1522.5\end{array}$ & $\begin{array}{l}2045.4 \\
1507.1\end{array}$ \\
\hline
\end{tabular}


TABLE 5. (contd)

\begin{tabular}{|c|c|c|c|c|c|c|c|}
\hline Month-Year & Location & Rod 1 & Rod 2 & Rod 3 & Rod 8 & Rod 5 & Rod 6 \\
\hline $5-79$ & $\begin{array}{l}\text { UTC } \\
\text { LTC }\end{array}$ & $\begin{array}{l}2059.5 \\
1501.5\end{array}$ & $\begin{array}{l}1983.3 \\
1473.0\end{array}$ & $\begin{array}{l}1991.0 \\
1501.1\end{array}$ & $\begin{array}{l}1769.2 \\
1335.3\end{array}$ & $\begin{array}{l}2081.2 \\
1558.6\end{array}$ & $\begin{array}{l}2089.6 \\
1543.0\end{array}$ \\
\hline $7-79$ & $\begin{array}{l}\text { UTC } \\
\text { LTC }\end{array}$ & $\begin{array}{l}2111.3 \\
1541.6\end{array}$ & $\begin{array}{l}2034.1 \\
1513.1\end{array}$ & $\begin{array}{l}2041.2 \\
1541.6\end{array}$ & $\begin{array}{l}1819.0 \\
1375.3\end{array}$ & $\begin{array}{l}2132.1 \\
1599.0\end{array}$ & $\begin{array}{l}2141.5 \\
1583.3\end{array}$ \\
\hline $8-79$ & $\begin{array}{l}\text { UTC } \\
\text { LTC }\end{array}$ & $\begin{array}{l}2188.2 \\
1600.8\end{array}$ & $\begin{array}{l}2109.6 \\
1572.2\end{array}$ & $\begin{array}{l}2116.0 \\
1601.6\end{array}$ & $\begin{array}{l}1893.3 \\
1434.8\end{array}$ & $\begin{array}{l}2208.0 \\
1659.0\end{array}$ & $\begin{array}{l}2218.6 \\
1642.9\end{array}$ \\
\hline $10-79$ & $\begin{array}{l}\text { UTC } \\
\text { LTC }\end{array}$ & $\begin{array}{l}2274.0 \\
1666.4\end{array}$ & $\begin{array}{l}2194.1 \\
1638.1\end{array}$ & $\begin{array}{l}2200.0 \\
1668.9\end{array}$ & $\begin{array}{l}1976.7 \\
1501.7\end{array}$ & $\begin{array}{l}2293.0 \\
1726.2\end{array}$ & $\begin{array}{l}2304.7 \\
1709.1\end{array}$ \\
\hline $11-79$ & $\begin{array}{l}\text { UTC } \\
\text { LTC }\end{array}$ & $\begin{array}{l}2338.2 \\
1716.5\end{array}$ & $\begin{array}{l}2257.2 \\
1688.3\end{array}$ & $\begin{array}{l}2262.6 \\
1720.0\end{array}$ & $\begin{array}{l}2039.0 \\
1552.4\end{array}$ & $\begin{array}{l}2356.6 \\
1777.2\end{array}$ & $\begin{array}{l}2369.2 \\
1759.5\end{array}$ \\
\hline $12-79$ & $\begin{array}{l}\text { UTC } \\
\text { LTC }\end{array}$ & $\begin{array}{l}2414.9 \\
1776.3\end{array}$ & $\begin{array}{l}2332.4 \\
1747.9\end{array}$ & $\begin{array}{l}2337.0 \\
1780.6\end{array}$ & $\begin{array}{l}2113.0 \\
1612.5\end{array}$ & $\begin{array}{l}2432.3 \\
1837.8\end{array}$ & $\begin{array}{l}2446.2 \\
1819.8\end{array}$ \\
\hline $1-80$ & $\begin{array}{l}\text { UTC } \\
\text { LTC }\end{array}$ & $\begin{array}{l}2436.3 \\
1792.9\end{array}$ & $\begin{array}{l}2353.4 \\
1764.6\end{array}$ & $\begin{array}{l}2357.9 \\
1797.5\end{array}$ & $\begin{array}{l}2133.8 \\
1629.4\end{array}$ & $\begin{array}{l}2453.5 \\
1854.8\end{array}$ & $\begin{array}{l}2467.8 \\
1836.6\end{array}$ \\
\hline $3-80$ & $\begin{array}{l}\text { UTC } \\
\text { LTC }\end{array}$ & $\begin{array}{l}2450.1 \\
1804.0\end{array}$ & $\begin{array}{l}2366.8 \\
1775.4\end{array}$ & $\begin{array}{l}2370.8 \\
1808.4\end{array}$ & $\begin{array}{c}14.8(d) \\
12.3\end{array}$ & $\begin{array}{l}2466.4 \\
1866.0\end{array}$ & $\begin{array}{l}2481.3 \\
1847.8\end{array}$ \\
\hline $4-80$ & $\begin{array}{l}\text { UTC } \\
\text { LTC }\end{array}$ & $\begin{array}{l}2508.6 \\
1851.4\end{array}$ & $\begin{array}{l}2423.8 \\
1821.9\end{array}$ & $\begin{array}{l}2425.3 \\
1855.0\end{array}$ & $\begin{array}{l}77.1 \\
64.8\end{array}$ & $\begin{array}{l}2520.9 \\
1913.9\end{array}$ & $\begin{array}{l}2538.6 \\
1895.9\end{array}$ \\
\hline $5-80$ & $\begin{array}{l}\text { UTC } \\
\text { LTC }\end{array}$ & $\begin{array}{l}2534.1 \\
1872.1\end{array}$ & $\begin{array}{l}2448.7 \\
1842.1\end{array}$ & $\begin{array}{l}2449.2 \\
1875.3\end{array}$ & $\begin{array}{r}104.5 \\
87.6\end{array}$ & $\begin{array}{l}2544.8 \\
1934.7\end{array}$ & $\begin{array}{l}2563.6 \\
1916.8\end{array}$ \\
\hline
\end{tabular}
(a) To convert to MWd/MTM multiply by 11.6 .
(b) Upper thermocouple.
(c) Lower thermocoup 1e.
(d) At this time rod 8 was replaced by rod 9 . 


\section{REFERENCES}

Beyer, C. E., et a1. November 1975. GAPCON-THERMAL-2: A Computer Program for Calculating the Thermal Behavior of an Oxide Fuel Rod. BNWL-1898, pacific Northwest Laboratory, Richland, Washington.

Bradley, E. R., et a1. 1979a. An Evaluation of the In-Pile Pressure Data from Instrumented Fuel Assemblies IFA-431 and IFA-432. NUREG/CR-1139, PNL-3206, Pacific Northwest Laboratory, Richland, Washington.

Bradley, E. R., et al. 1979b. "Burnup Dependent Fission Gas Release." Irans. ANS $33: 272-273$.

Brite, 0. W., et a1. June 1975. EEI/EPRI Fuel Densification Project-Research Project 131 Final Report. Prepared for the Electric Power Reserach Institute by Pacific Northwest Laboratory, Richland, Washington.

Crouthame1, C. E., and M. D. Freshley. October 1980. Fuel Performance Improvement Program: Semiannua I Progress Report, ApriT $1980-$ September 1980. DOE/ET/34215-19.

Cunningham, M. E., et a1. 1978. Stored Energy Calculation: The State of the Art. PNL-2581, Pacific Northwest Laboratory, Richland, washington.

*Cunningham, M. E., R. E. Williford, and C. R. Hann. 1979. Effects of Fill Gas Composition and Pellet Eccentricity; Compar isons Between Instrumented FueT Assemblies IFA-431 and IFA-432. NUREG/CR-0331, PNL-2729, Pacific Northwest Laboratory, Richland, Washington.

Hann, C. R., et al. November 1977. Test Design, Pre-Characterization and Fuel Assembly Fabrication for Instrumented Fuel AssembTies IFA-43I and IFA-432. BNWL-1988, Pacific Northwest Laboratory, Richland, Washington.

Hann, C. R., et a1. 1978a. Data Report for the NRC/PNL Halden Assembly IFA-431. PNL-2494, Pacific Northwest Laboratory, Richland, Washington.

*Hann, C. R., et a 1. 1978b. Data Report for the NRC/PNL Halden Assembly IFA-432, NUREG/CR-0560, PNL-2673, Pacific Northwest Laboratory, Richland, Washington.

Hann, C. R., and R. K. Marsha11. 1977. Comparative Analys is of PelletCladding Interaction from IFA-431 and IFA-432 HaTden Reactor Tests. BNWL-2240, Pacific Northwest Laboratory, Richland, Washington.

Lanning, D. D., B. 0. Barnes, and W. A. Scheffler. 1980. "Use of Fuel Thermocoup le Transient Response for Data Verification and Fuel Rod Modeling." Nuclear Tech. 50:95-107. 
*Lanning, D. D., B. 0. Barnes, and R. E. Williford. 1979. Manifestations of Non 1 inearity in Fuel Center Thermocouple Steady-State and Transient Data: Implications for Data Analysis. NUREG/CR-0220, PNL-2692, Pacific Northwest Laboratory, Richland, washington.

Lyons, M. F., et a1. 1964. UO, Pellet Thermal Conductivity from Irradiation with Central Me Iting. GEAP-4624, General Electric Company, San Jose, California.

* Nealley, C. et al. 1979. Postirradiation Data Analys is for NRC/PNL Halden Assemby IFA-431. NUREG/CR-0797, PNL-2975, Pacific Northwest Laboratory, Richland, Washington.

* Williford, R. E., et al. 1980. The Analys is of Fuel Relocation for the NRC/PNL Halden Assemb iies IFA-431, IFA-432, and IFA-513; An Interim Report. NUREG/CR-0588, PNL-2709, Pacific Northwest Laboratory, Richland, washington.

Williford, R. E., and C. R. Hann. July 1977. Effects of Fill Gas Composition and Pellet Eccentricity. BNWL-2285, Pacific Northwest Laboratory, Richland, Washington.

*These reports are available for purchase from the NRC/GPO Sales Program, U.S. Nuclear Regulatory Commission, Washington, D.C. 20555, and/or the National Technical Information Service, Springfield, VA. 22161. 
APPENDIX A

FUEL ROD AND FUEL COLUMN SCHEMATICS FOR IFA-432 


\section{APPENDIX A}

FUEL ROD AND FUEL COLUMN SCHEMATICS FOR IFA-432

This appendix illustrates the fuel rod and fuel column schematics for instrumented fuel assembly (IFA)-432, which is being irradiated in the Halden boiling water reactor (HBWR) in Halden, Norway.

A.1 


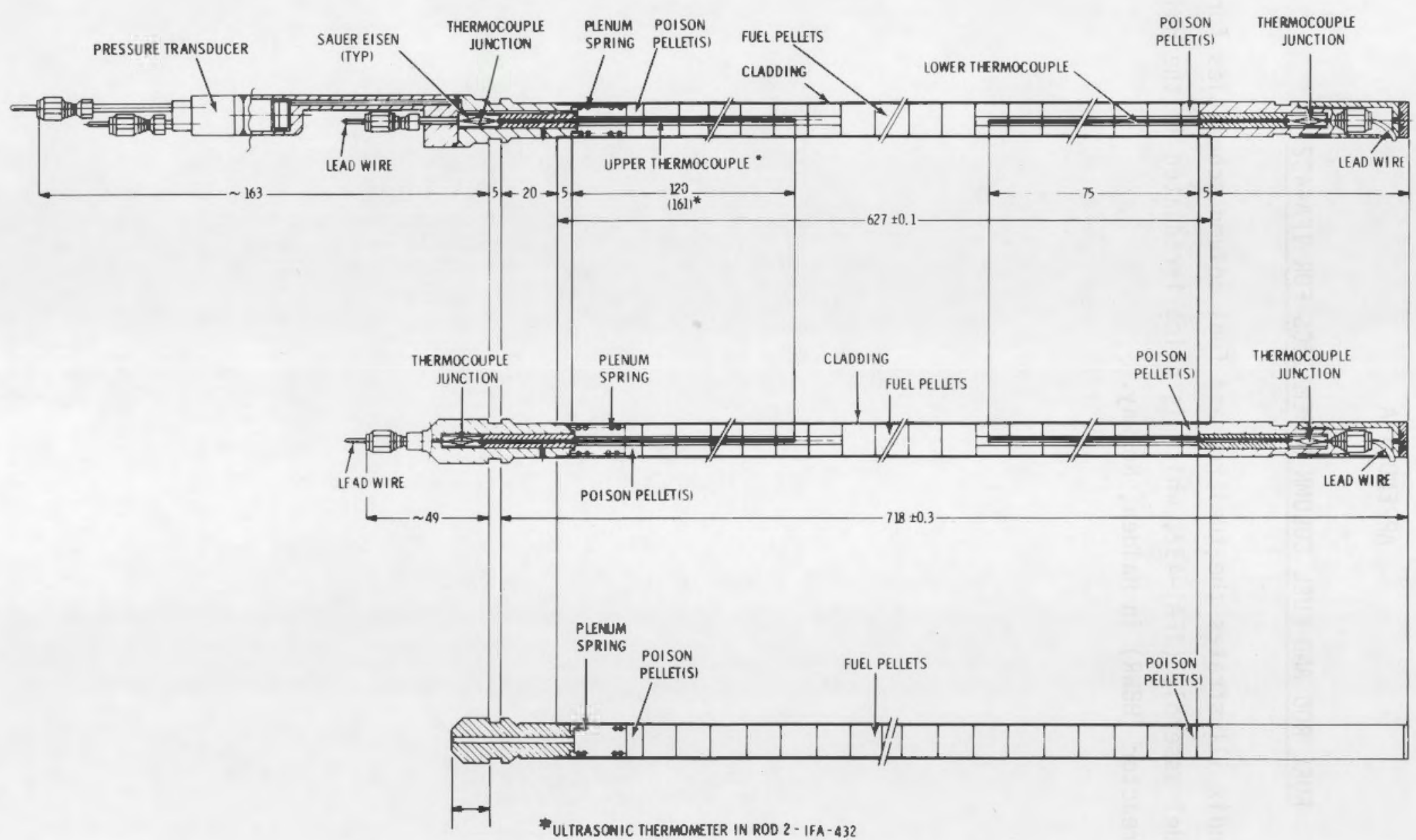

FIGURE A.1. Schematic Arrangement of Fuel Rods for IFA-432 


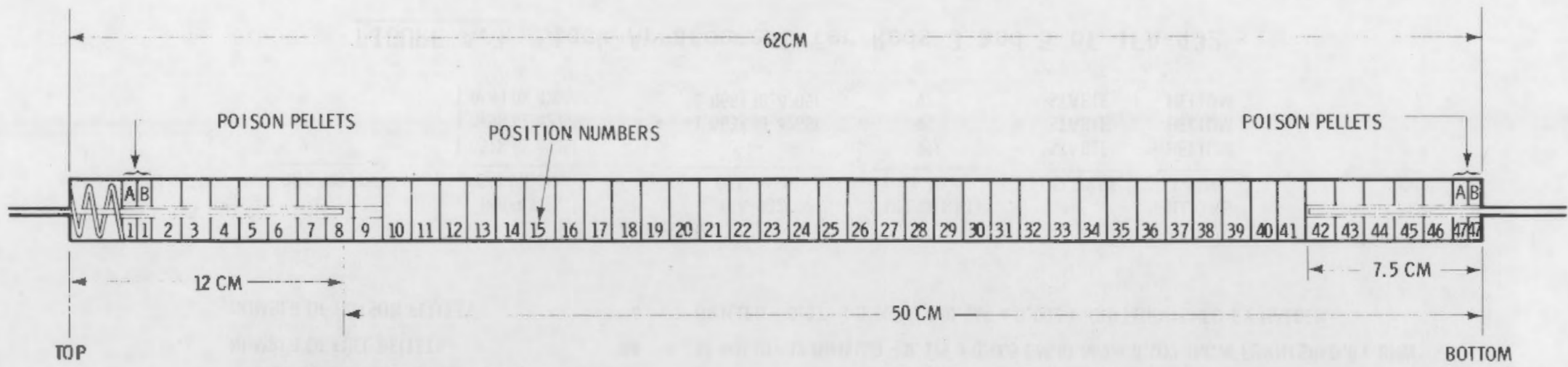

TOTAL NUMBER OF PELLETS IN EACH STACK - 49

NUMBER OF FUEL PELLETS - $\quad 4532$ SOLIO, 13 DRILLED $-0.175 \mathrm{CM} \pm 0.005 \mathrm{CM} 10.069 \pm 0.002$ INCHI FURNISHED BY BNW

NUMBER OF POISON PELLETS - $\quad 4$ DRILLED $-0.175 \mathrm{CM} \pm 0.005 \mathrm{CM}(0.069 \pm 0.002$ INCH) FURNISHED BY HALDEN

\begin{tabular}{|c|c|c|c|c|c|}
\hline \multirow[b]{2}{*}{ ROD NO. } & \multicolumn{2}{|c|}{ PELLET DIAMETER } & \multirow[b]{2}{*}{$\begin{array}{c}\text { FUEL DENSITY } \\
\text { \$ TD }\end{array}$} & \multirow[b]{2}{*}{ FUEL TYPE } & \multirow[b]{2}{*}{$\begin{array}{c}\text { FILL GAS } \\
\text { I ATM }\end{array}$} \\
\hline & $\begin{array}{l}\text { IFA-431 } \\
C M \text { (inch) }\end{array}$ & $\begin{array}{l}\text { IFA-432 } \\
\text { CM (inch) }\end{array}$ & & & \\
\hline 1 & $1.0681(0.4205)$ & $1.0681(0.4205)$ & 95 & STABLE & HELIUM \\
\hline 6 & $1.0681(0.4205)$ & $1.0681(0.4205)$ & 92 & UNSTABLE & HELIUM \\
\hline
\end{tabular}

FIGURE A.2. Stack Arrangement for Rods 1 and 6 of IFA-432 of IFA-432 


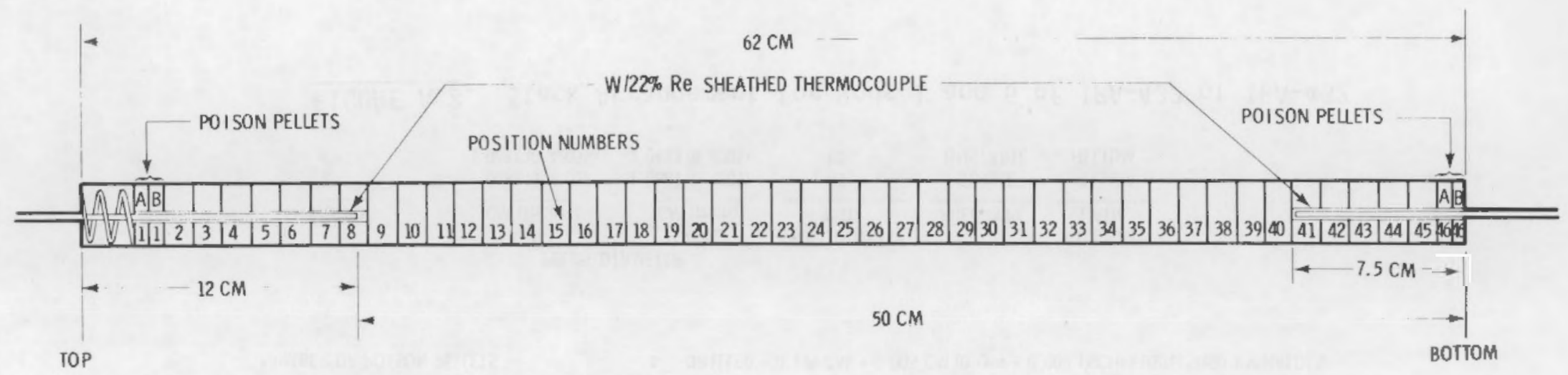

TOTAL NUMBER OF PELLETS IN EACH STACK - 48 NUMBER OF FUEL PELLETS -

4432 SOLID, 12 DRILLED $-0.175 \pm 0.005 \mathrm{CM}(0.069 \pm 0.002$ INCH) FURNISHED BY BNW NUMBER OF POISON PEUETS DRILLED $-0.175 \pm 0.005$ CM $(0.069 \pm 0.002$ INCH) FURNISHED BY HALDEN

\begin{tabular}{|c|c|c|c|c|c|}
\hline \multirow[b]{2}{*}{ ROD NO. } & \multicolumn{2}{|c|}{ PELLET DIAMETER } & \multirow[b]{2}{*}{$\begin{array}{l}\text { FUEL DENSITY } \\
\approx \mathrm{TD} \\
\end{array}$} & \multirow{2}{*}{ FUEL TYPE } & \multirow[b]{2}{*}{$\begin{array}{l}\text { FILLGAS } \\
\text { I ATM }\end{array}$} \\
\hline & $\begin{array}{l}\text { IfA-431 } \\
\text { CM (inch) }\end{array}$ & $\begin{array}{l}\text { IFA-432 } \\
\text { CM (inch) }\end{array}$ & & & \\
\hline 2 & 1.052810 .41 & -- & 95 & SIABLE & HELIUM \\
\hline 3 & $1.0858(0.42 \pi)$ & $1.0833(0.4265)$ & 95 & STABLE & HELIUM \\
\hline & $1.0681(0.4205)$ & $1.0681(0.4205)$ & & & \\
\hline
\end{tabular}

FIGURE A.3 Stack Arrangement for Rods 3 and 5 of IFA-432 


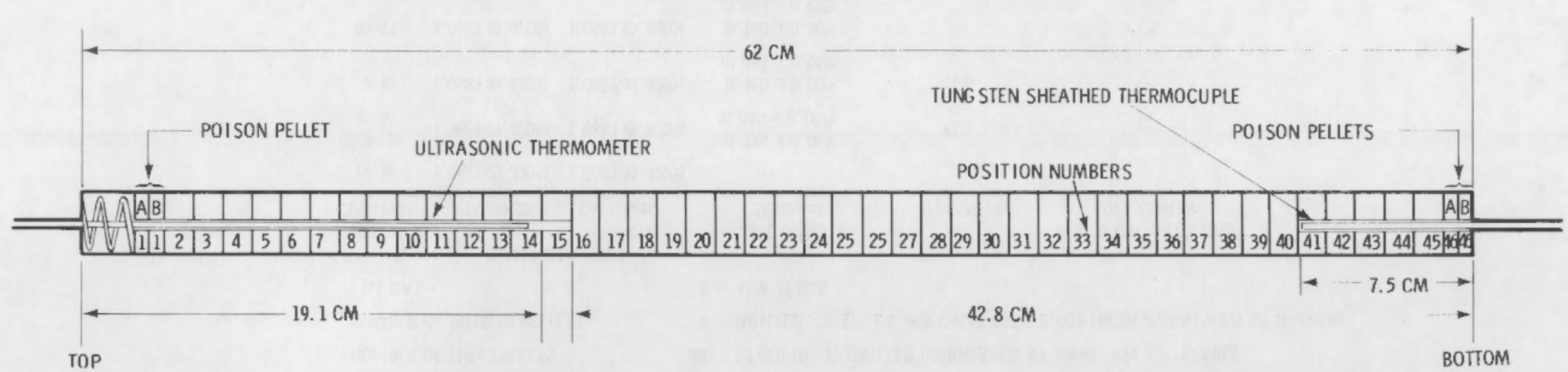

is

TOTAL NUMBER OF PELLETS IN EACH STACK - 48 NUMBER OF FUEL PELLETS NUMBER OF POISON PELLETS -
4432 SOLID. 12 DRILLED $-0.175 \pm 0.005 \mathrm{CM}(0.069 \pm 0.002$ INCH) FURNISHED BY BNW 4 DRILLED $-0.175 \pm 0.005 \mathrm{CM}(0.069 \pm 0.002$ INCH) FURNISHED BY HALDEN

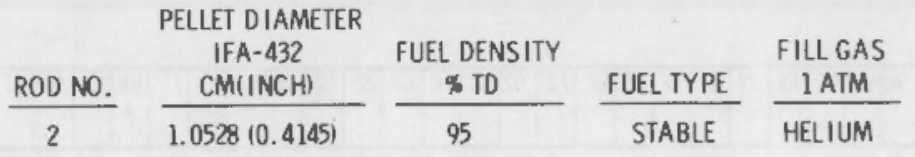

FIGURE A.4. Stack Arrangement for Rod 2 of IFA-432 


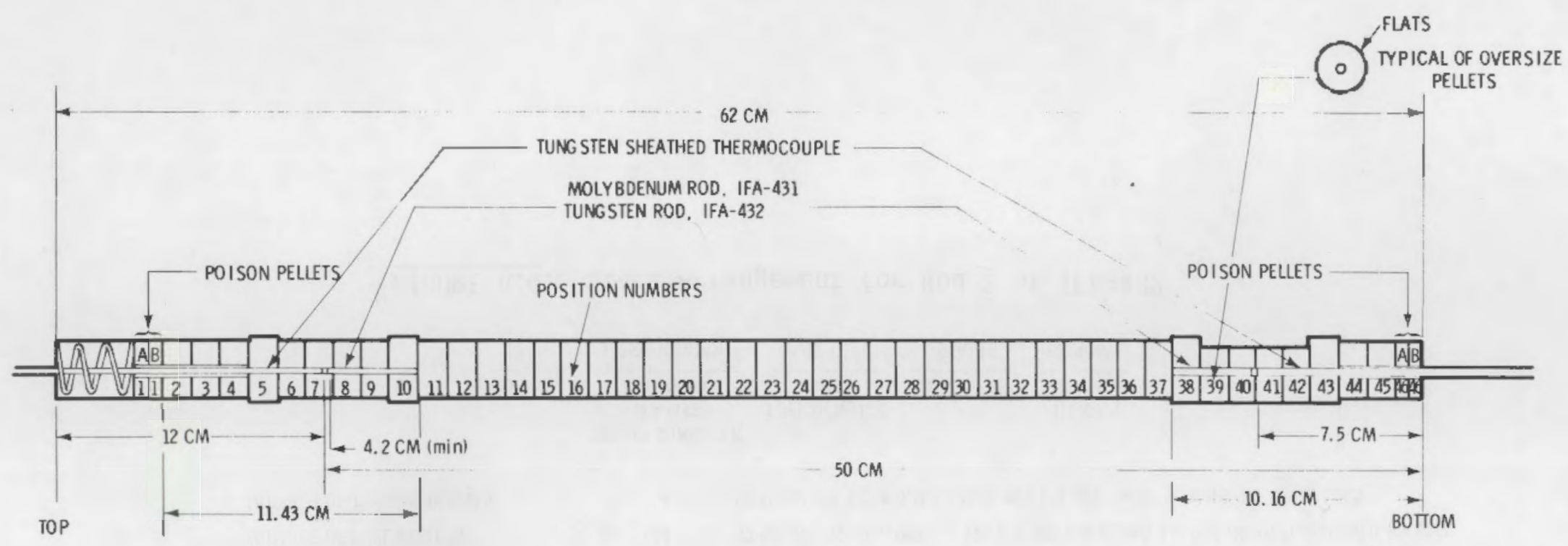

TOTAL NUMBER OF PELLETS IN STACK NUMBER OF FUEL PELLETS -

4427 SOLID, 17 DRILLFD (FURNISHED BY BNW), 95\% TD, STABLE

NUMBER OF POISON PELLEIS -

FILL GAS -

1 ATM XENON

\begin{tabular}{|c|c|c|c|c|c|}
\hline $\begin{array}{l}\text { PEUET } \\
\text { POSITION } \\
\end{array}$ & $\begin{array}{l}\text { IFA-431 } \\
\text { CM (inch) } \\
\end{array}$ & $\begin{array}{r}\text { IFA-432 } \\
\text { CM (inch) } \\
\end{array}$ & $\begin{array}{l}\text { HOLE DIAMETER } \\
\text { CM (inch) } \\
\end{array}$ & ON CENTER & $\begin{array}{l}0.0127 \mathrm{CM} 10.005 \text { INCH) } \\
\text { OFF CENTER }\end{array}$ \\
\hline $12-38$ & $1.0681(0.4205)$ & $1.0681(0.4205)$ & -- & -- & -- \\
\hline $\begin{array}{r}3-5 \\
45-46\end{array}$ & $1.0681(0.4205)$ & $1.0581(0.4205)$ & $\begin{array}{r}0.175 \pm 0.005 \\
10.069 \pm 0.002)\end{array}$ & YES & -- \\
\hline $7-10$ & $1.0681(0.4205)$ & $1.0687(0.4205)$ & $\begin{array}{c}0.160 \pm 0.005 \\
(0.063 \pm 0.002)\end{array}$ & YES & - \\
\hline $40-43$ & $1.0681(0.4205)$ & $1.0681(0.4205)$ & $\begin{array}{c}0.160 \pm 0.005 \\
10.063 \pm 0.0021\end{array}$ & -- & YES \\
\hline $\begin{array}{l}6,11 \\
39,44\end{array}$ & $1.0858(0.4275)$ & $1.0833(0.4265)$ & $\begin{array}{c}0.160 \pm 0.005 \\
10.063 \pm 0.002\end{array}$ & YES & - \\
\hline
\end{tabular}

FIGURE A.5. Stack Arrangement for Rod 4 of IFA-432 (Xenon Fill Gas) 


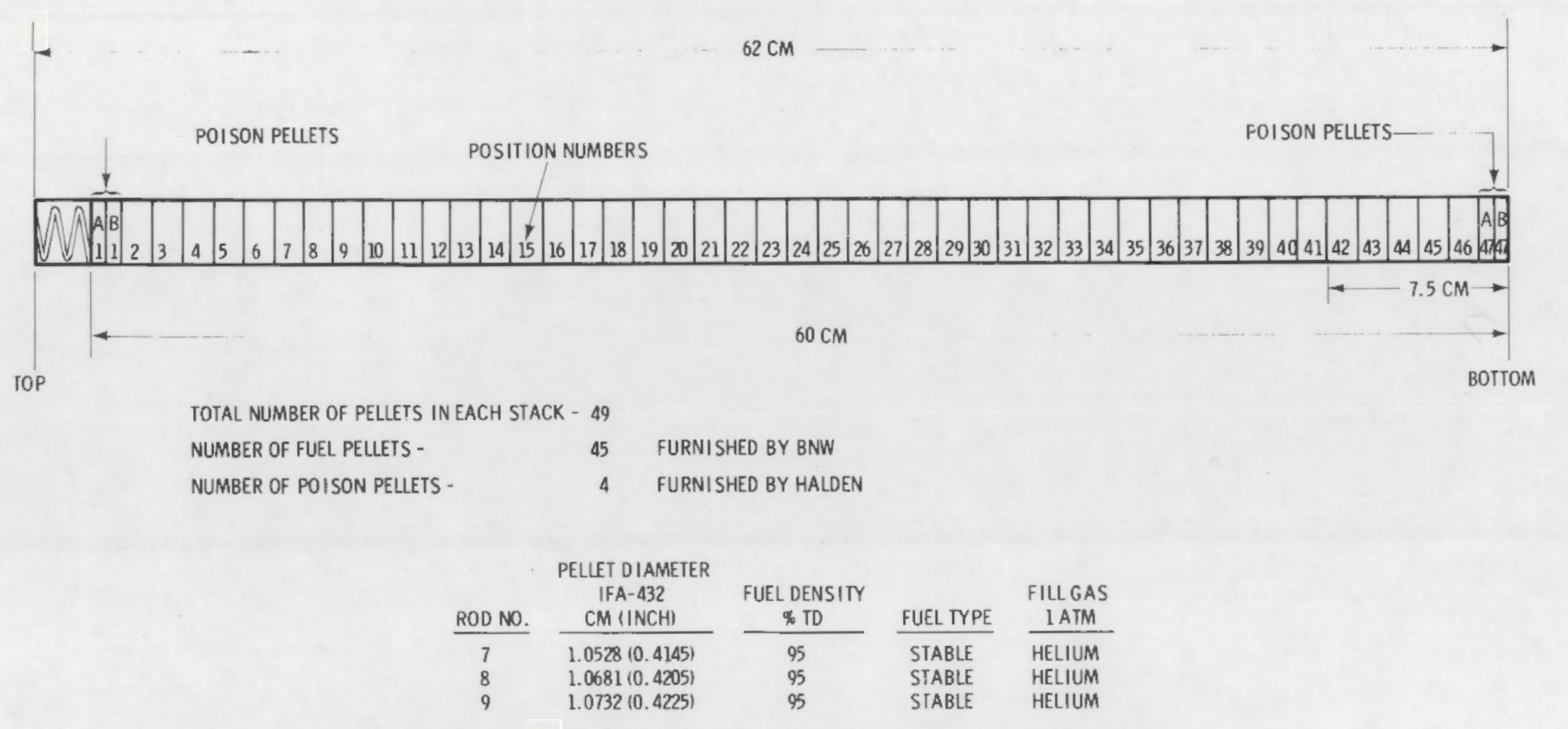

FIGURE A.6. Stack Arrangement for Noninstrumented Replacement Rods 7, 8, and 9 of IFA-432 


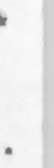


APPENDIX B

DATA PROCESSING 
APPENDIX B

\section{DATA PROCESSING}

The data received from Halden on magnetic tape are processed as shown in Figure B.1. After the data tapes are received, they are translated from the Halden IBM/1800 language (EBCDIC) to the PDP11/70 language (ANSI); the translated version is then stored on tape. The tape is formatted so that all data from a particular time on a particular date are in one block; all data are simultaneously stored on a disk file.

Once the raw data are stored on disk, another program corrects the rod local heat ratings at the thermocouple (TC) locations for radial flux tilt across the assembly. Rod local and assembly powers are corrected for axial flux shape and heat losses to the moderator, and corrections for local mass distributions of fissile material for each rod are made.

While this is being done, other checks are made on the data. A total heat balance check is made for the assembly and rod average powers during application of the axial correction factor to account for the difference between the average and true mean of the axial flux distribution. The first attempt at this uses an axial profile that represents normal operating conditions. If the heat balance for this profile does not check, a second attempt is made with an axial flux shape that represents a disturbed flux profile. This occurs when a nearby control rod is partially inserted.

After this step, another program corrects burnups and heat ratings for depletion of ${ }^{235} \mathrm{U}$. 


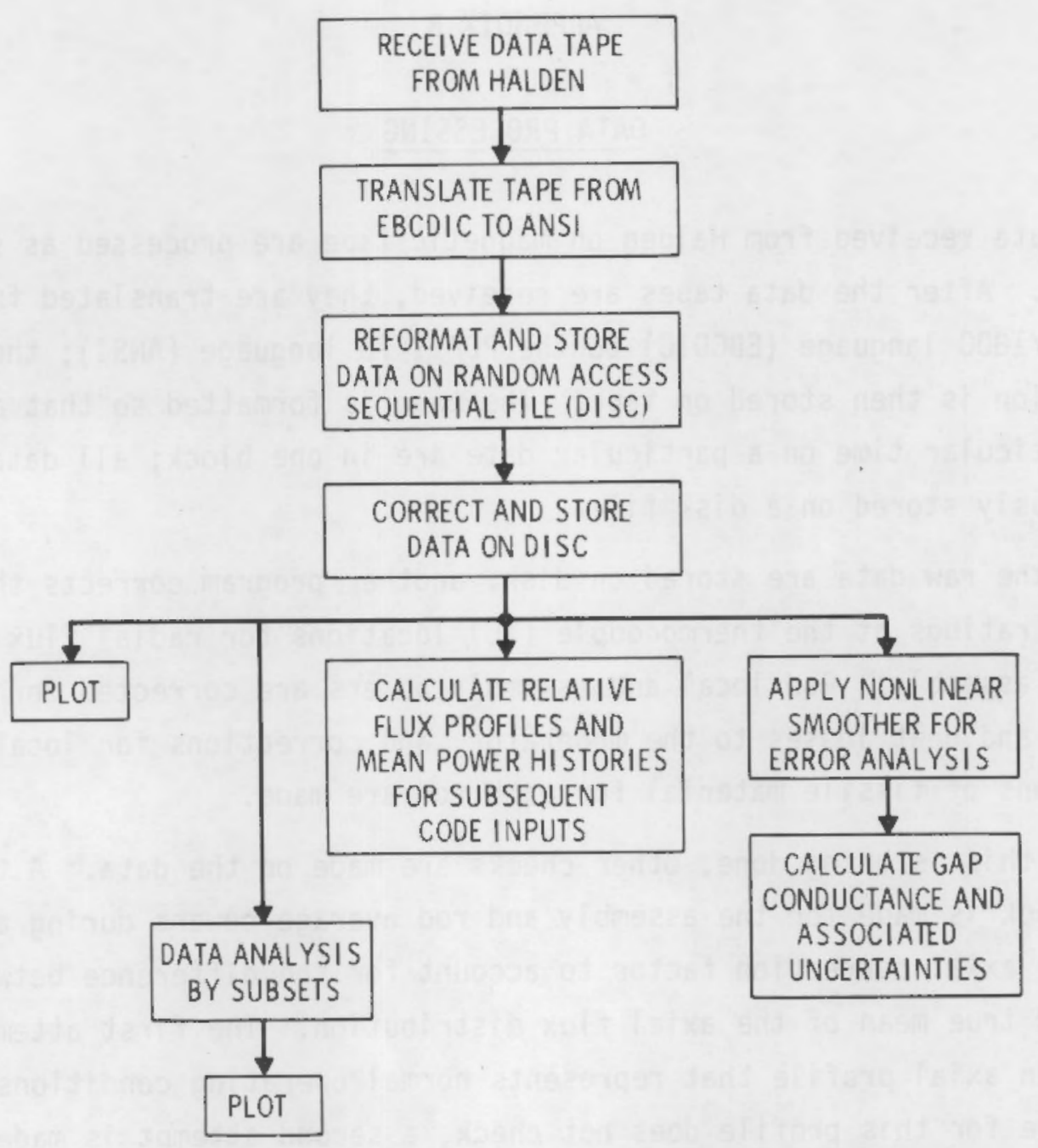

FIGURE B.1. Flow Diagram for Processing Halden Data 


\section{APPENDIX C}

INSTRUMENT DESCRIPTIONS AND CALIBRATION 


\section{APPENDIX C}

\section{INSTRUMENT DESCRIPTIONS AND CAL IBRATION}

Instrumented fue 1 assembly (IFA)-432 was equipped with a comprehensive array of in-pile instrumentation to collect data (see text Figures 1 and 2, pp. 6 and 7). The most important of these instruments were:

- 6 vanadium beta emitter self-powered neutron detectors (SPNDS)

- 1 cobalt fast-response SPND

- $11 \mathrm{~W} 5 \% \mathrm{Re} / \mathrm{W} 26 \%$ Re-sheathed fuel centerline thermocouples (TCS)

- 1 ultrasonic thermometer

- 6 linear variable differential transformer (LVDT) cladding elongation monitors

- 3 diaphragm-type rod internal pressure transducers.

Each of these is briefly disccused below. The accuracy and uncertainty of the ir respective outputs is discussed more completely in Hann et al. (1977).

\section{NEUTRON DETECTORS}

IFA-432 is equipped with six vanadium self-powered beta current neutron detectors (Figure C.1) to monitor the power in the fuel assembly after the initial thermal-hydraulic calibration. Each detector is $100 \mathrm{~mm}$ (3.93 in.) long and is positioned so that the center of the detector and the TC junction are located on essentially the same plane.

The neutron detectors used in IFA-432 were not calibrated. Their precisions were based on the results of the irradiation of 30 similar vanadium neutron detectors in the Studsvik R2-0 Reactor in Sweden. The 30 detectors were irradiated in a thermal neutron flux of $1.1 \times 10^{14} \mathrm{n} / \mathrm{m}^{2}-\mathrm{s}$. The error 1 imits for the outputs of the detectors were estimated to be $\pm 2.5 \%$ at a neutron flux of $1.1 \times 10^{14} \mathrm{n} / \mathrm{m}^{2}-\mathrm{s}$. 


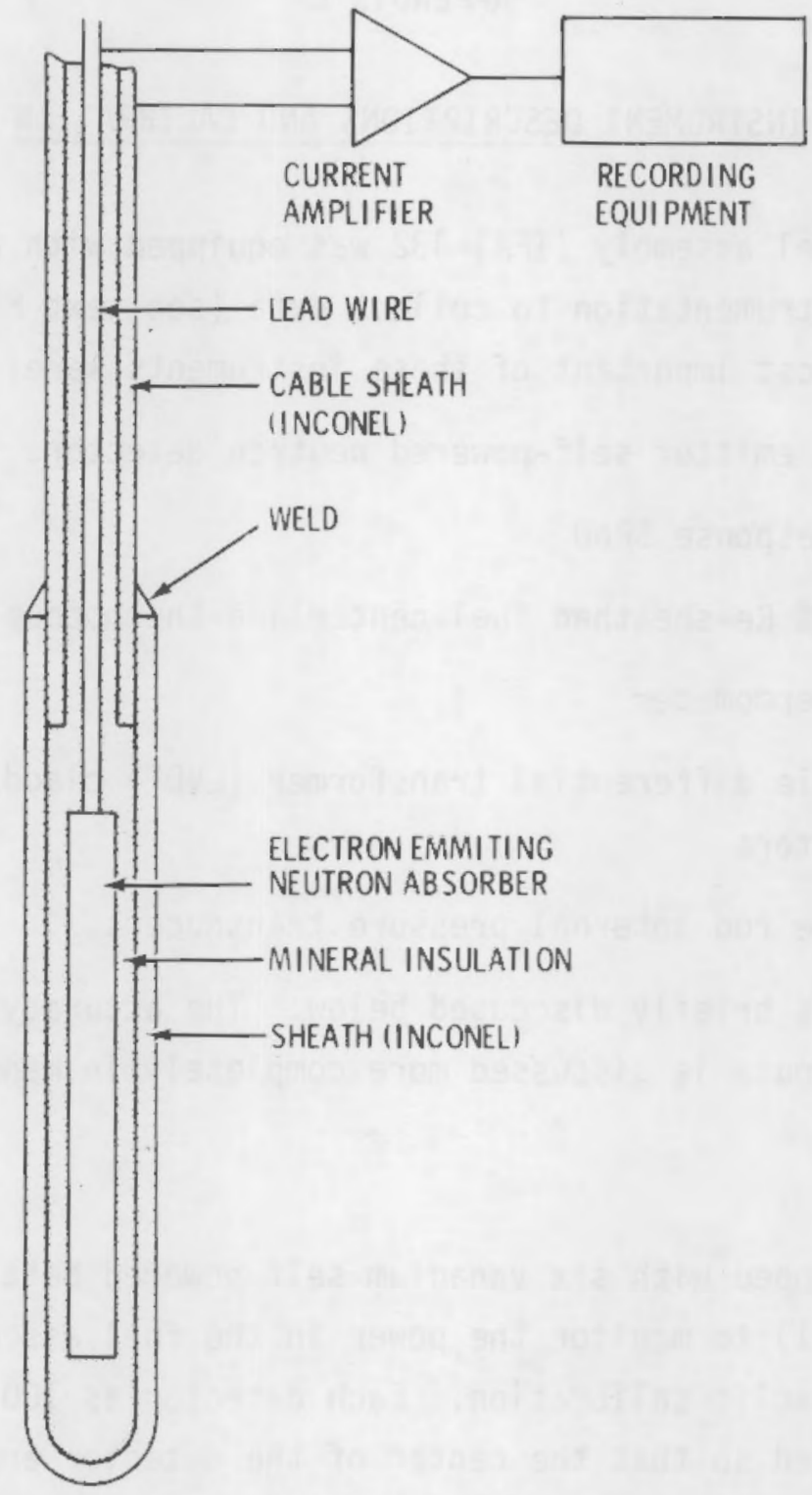

FIGURE C.1. Schematic of Self-Powered Beta Current Neutron Detector

In addition to correlating the detector outputs to the neutron flux in the Studsvik Reactor, Halden has conducted long-term tests of similar neutron detectors in the Halden boiling water reactor (HBWR). These tests have established the detectors as reliable and accurate instruments without a measurable change in sensitivity at the higher flux levels. 
The sensitivities of the test assembly neutron detectors were calculated from the sensitivities of the calibrated detectors and the physical characteristics of the test assembly detectors supplied by the manufacturer. The gamma sensitivity was not measured and is considered to be negligible by Halden.

The vanadium detectors have a calculated burnup rate of $0.013 \%$ per month at a neutron flux of $1 \times 10^{17} \mathrm{n} / \mathrm{m}^{2}-\mathrm{s}$. Based on this rate, the neutron detector end-of-life (EOL) burnup for IFA-432 is $0.3 \%$. Because of this low value, the neutron detector outputs were not corrected for burnup. However, it should be noted that during up and down power ramps a correction factor should be considered for the output values because of the slow response time of the vanadium detectors. (a)

The cobalt detector, which is similar in appearance to the vanadium detector but $200 \mathrm{~mm}$ long, was placed in the center of the assembly to monitor average assembly power during transient tests (Lanning and Hann 1977).

\section{FUEL THERMOCOUPLES}

The 11 TCs that were used in IFA-432 to measure the central fuel temperatures had grounded junctions with $1.575-\mathrm{mm}(0.062-$ in.) outside diameter (OD) tungsten $/ 22 \%$ rhenium sheaths and $\mathrm{W} 5 \% \mathrm{Re} / \mathrm{W} 26 \%$ Re seven-stranded TC wires with thorium oxide insulators (Figure C.2). The sensor in the top of rod 2 was an ultrasonic thermometer (Lynnworth et a1. 1969) that failed immediately.

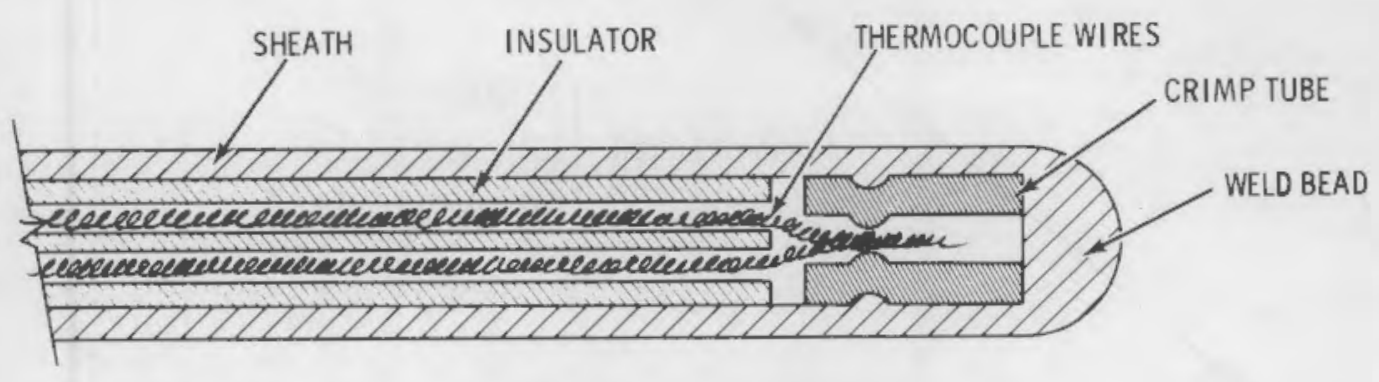

FIGURE C.2. Schematic of $W 5 \% \mathrm{Re} / \mathrm{W} 26 \%$ Re Thermocouples with Grounded Junction

(a) $5.5 \mathrm{~min}, 0$ to $63 \%$. 
The TCs were fabricated and calibrated by the Idaho National Engineering Laboratory (INEL); the calibration curve for the tungsten-rhenium TCs is shown in Figure C.3. Calibration of the TCS over the range of use produces a brittle assembly that is fragile and subject to breakage; consequently, only one TC, which was not used in the in-reactor test, was calibrated.

The tungsten-rhenium TC was calibrated against a reference TC of bare W 5\% $\mathrm{Re} / \mathrm{W} 26 \% \mathrm{Re}$ and an optical pyrometer (as a second reference). The reference TC and the optical pyrometer agreed within $295 \mathrm{~K}\left(40^{\circ} \mathrm{F}\right)$ up to $2477 \mathrm{~K}\left(4000^{\circ} \mathrm{F}\right)$; but as the temperature approached $2755 \mathrm{~K}\left(4500^{\circ} \mathrm{F}\right)$, the difference between the two widened. The optical pyrometer was thought to be closer since the $2755 \mathrm{~K}$ temperature is above that given in most calibration tables for W/Re TCs. The calibrated TC had the following limits of error:
- ambient to $811 \mathrm{~K}\left(1000^{\circ} \mathrm{F}\right)$
$= \pm 5.5 \mathrm{~K}\left(10^{\circ} \mathrm{F}\right)$
- 811 to $2477 \mathrm{~K}\left(1000\right.$ to $4000^{\circ} \mathrm{F}$ )
$= \pm 1 \%$ of reading
- 2477 to $2755 \mathrm{~K}\left(4000\right.$ to $\left.4500^{\circ} \mathrm{F}\right)= \pm 2 \%$ of reading.

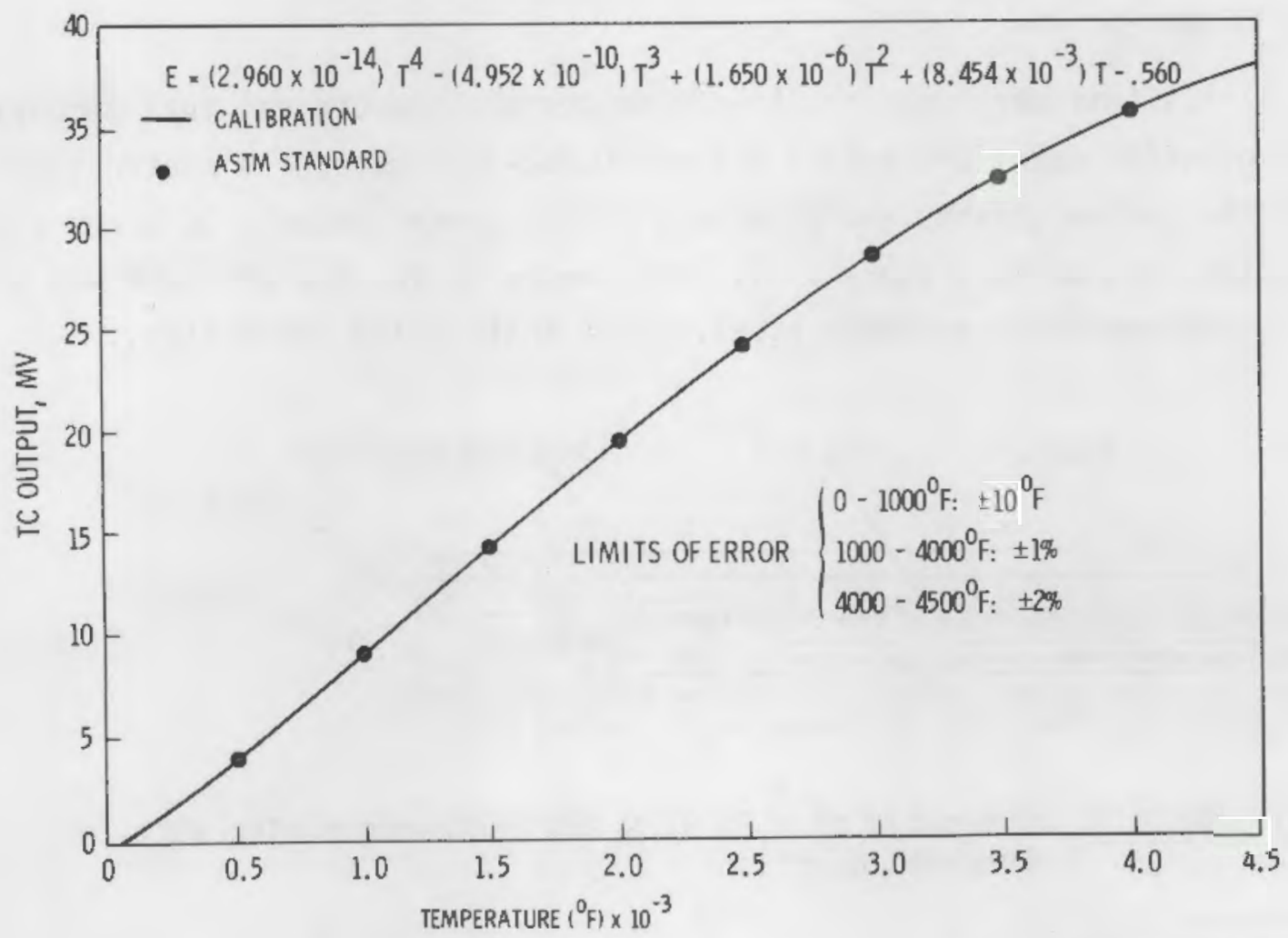

FIGURE C.3. Calibration Curve for W $5 \%$ Re/W $26 \%$ Re Thermocouples 
Irradiation of the TCS will have long-term effects caused by the shunting of the EMFs by conduction across the insulators, transmutations in the TC materials, and temperature gradients along the TC wires. The insulator shunting effect was reduced to a negligible level by using thorium oxide insulators.

Decalibration of TCs during irradiation is not well defined at the present time. Experimental data from Halden and analysis of the IFA-432 transient data suggest possible decalibration of up to $1 \% / 100 \mathrm{GJ} / \mathrm{kgU}$ burnup. Consequently, the measured fuel temperatures could be $20 \%$ lower than the actual temperatures at the end of the current reporting period; and, therefore, TC decalibration should be considered when using these data.

\section{CLADDING ELONGATION MONITORS}

Figure C.4 is a schematic of the LVDT cladding elongation sensors used in IFA-432. These instruments are mounted upside down at the bottom of the assembly with the core extension contacting the lower end plug of the rod. The ferromagnetic core is attached to the extension and moves inside a coil system with the central primary coil carrying 50-mA 400- $\mathrm{Hz}$ excitation. A secondary coil consisting of two balanced halves flanks the primary coil. The output voltage is zero when the core is in its central position and increases linearly when the cladding elongation moves the core. Sample calibration curves for these instruments may be found in Hann et al. (1978).

\section{FISSION GAS PRESSURE TRANSDUCERS}

Figure C.5 shows a schematic of the diaphragm-type pressure transducer used to measure the internal rod pressures due to fission gas release during irradiation. It is essentially an on-off measurement. The thin platinum alloy membrane is exposed to the rod internal gases on one side, while the other side is connected to an external pressure manifold. When the external pressure equals the internal pressure, the deflection of the membrane causes it to make an electrical contact. The step increase in voltage signals a null pressure balance. Over a range of $10 \mathrm{MPa}\left(100 \mathrm{~kg} / \mathrm{cm}^{2}\right)$, the sensitivity of the instrument is $0.01 \mathrm{MPa}\left(0.1 \mathrm{~kg} / \mathrm{cm}^{2}\right)$ and the accuracy and repeatability are $\pm 0.1 \mathrm{MPa}\left( \pm 1 \mathrm{~kg} / \mathrm{cm}^{2}\right)$ and $\pm 0.04 \mathrm{MPa}\left( \pm 0.4 \mathrm{~kg} / \mathrm{cm}^{2}\right)$, respectively. 


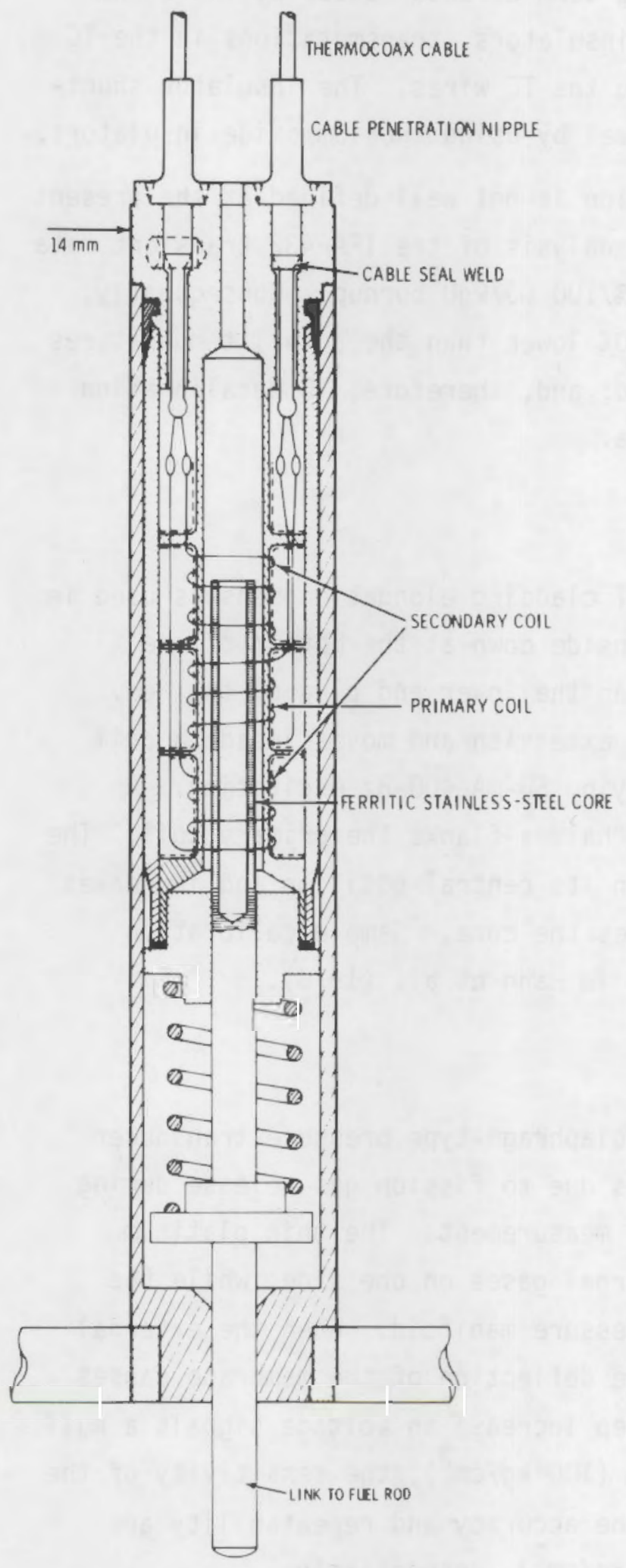

FIGURE C.4. Cladding Elongation Monitor (Halden Project Design) 


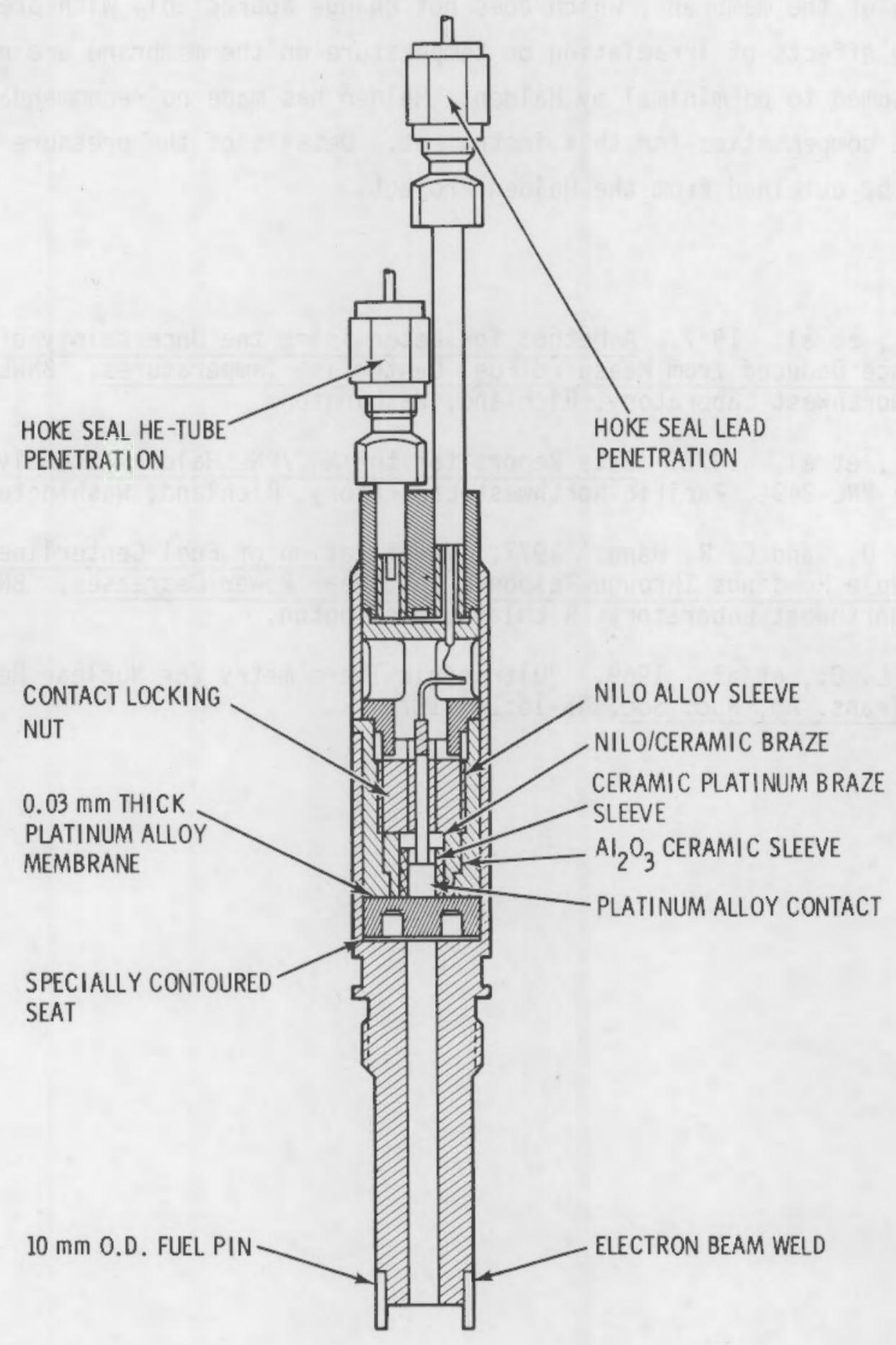

FIGURE C.5. Fission Gas Pressure Transducer (Halden Project Design) 
Calibration is done out-of-reactor and consists of checking the deflection sensitivity of the membrane, which does not change appreciably with pressure level. The effects of irradiation or temperature on the membrane are not known but are assumed to be minimal by Halden. Halden has made no recommendation for temperature compensation for this instrument. Details of the pressure transducer must be obtained from the Halden Project.

\section{REFERENCES}

Hann, C. R., et al. 1977. A Method for Determining the Uncertainty of Gap Conductance Deduced from Measured Fuel Centerline Temperatures. BNWL-2091, Pacific Northwest Laboratory, Richland, Washington.

Hann, C. R., et al. 1978. Data Report for the NRC/PNL Halden Assembly IFA-431. PNL-2494, Pac if ic Northwest Laboratory, Richland, Washington.

Lanning, D. D., and C. R. Hann. 1977. Verification of Fuel Centerline Thermocouple Readings Through Response to Linear Power Decreases. BNWL-2189, Pacific Northwest Laboratory, Richland, Washington.

Lynnworth, L. C., et al. 1969. "Ultrasonic Thermometry for Nuclear Reactors." In IEEE Trans. Am. NuC. Soc. NS-16:184-187. 


\section{APPENDIX D}

ASSEMBLY POHER CALIBRATION 


\section{ASSEMBLY POWER CALIBRATION}

The data report for the instrumented fuel assembly (IFA)-431 briefly explained the usual method for calibrating assemblies in the Halden reactor. (a) This procedure was not used in the case of IFA-432 because the calibration flow valve (text Figure 2, p. 7) failed in the norma? operating position, allowing only natural circulation. However, both assemblies were in the core simultaneously at the time of IFA-432 startup. The second assembly was calibrated by comparisons of total assembly power and rod 3 (small gap) power. The uncertainty in assembly power for IFA-432 was estimated to be $\pm 6 \%$.

(a) Hann, C. R., et a]. 1978. Data Report for the NRC/PNL Ha lden Assembly IFA-431. PNL-2494, Pacific Northwest Laboratory, RichTand, Washington. 



\section{DISTRIBUTION}

No. of

Copies

OFFSITE

\author{
A. A. Churm \\ DOE Patent Division \\ $9300 \mathrm{~S}$. Cass Avenue \\ Argonne, IL 60439 \\ 400 U.S. Nuclear Regulatory \\ Commission \\ Division of Technical \\ Information and Document \\ Control \\ 7920 Norfolk Avenue \\ Bethesda, MD 20014 \\ 2 DOE Technical Information Center \\ 4 G. P. Marino \\ Chief, Fuel Behavior Research \\ Branch \\ Division of Reactor Safety \\ Research \\ U.S. Nuclear Regulatory \\ Commission \\ Washington, DC 20555 \\ H. H. Scott \\ Division of Reactor Safety \\ Research \\ U.S. Nuclear Regulatory \\ Comunission \\ Washington, DC 20555
}

No, of

Copies

R. Van Houton

Fuel Behavior Research Branch

Division of Reactor Safety Research

U.S. Nuclear Regulatory Cominission

Washington, DC 20555

ONSITE

50 Pacific Northwest Laboratory

W. J. Bailey

J. 0. Barner

E. R. Bradley (7)

M. E. Cunningham (20)

S. K. Edler

M. D. Freshley

R. L. Goodman

R. J. Guenther

C. R. Hann

D. D. Lanning

R. K. Marsha 11

C. L. Mohr

C. Nealley

F. E. Panisko

W. N. Rausch

R. E. Schreiber

M. S. Smith

R. E. Williford

Technical Information (5)

Publishing Coordination BE (2) 

NRC FOAM 335

$(7.7)$
W.S. NUCLEAR REGULATORY COMMISSION

BIBLIOGRAPHIC DATA SHEET

4. TITLE AND SUBTITLE (Ado Volume No., if apropriore)

Data Report for the NRC/PNL Halden Assembly IFA,-432:

April 1978-May 1980

\begin{tabular}{lll}
\hline 7. AUTHOR(S) & E.R. Bradley & M.E. Cunningham \\
& D.D. Lanning & R.E. Williford
\end{tabular}

9. PERFORMING ORGANIZATION NAME AND MAILING ADDRESS (Inc/ude Zip Code)

Pacific Northwest Laboratory

Richland, WA 99352

12. SPONSORING OAGANIZATION NAME AND MAILING ADDRESS (Inciude $Z$ ip Code)

U.S. Nuclear Regulatory Commission

Division of Reactor Safety Research

Office of Nuclear Regulatory Research

Washington, DC 20555

1. REPORT NUMBER (Assigneo bV DOC)

NUREG/CR -1950

PNL -37 C9

2. (Leave biank)

3. RECIPIENT'S ACCESSION NO.

5. DATE REPORT COMPLETED

\begin{tabular}{l|l}
\hline MONTH & YEAA
\end{tabular}

February 1981

DATE REPORT ISSUED

MONTH YYEAR

Apri 1

1981

6. (Leave bank)

8. (Leave blank)

10. PROJECT/TASK/WORK UNIT NO

11. CONTRACT NO.

FIN No. B2043

PERIOD COVEREO (tnclusive adres)

Apri1 1978 - Hay 1980

15. SUPPLEMENTAAY NOTES

14. (Leave biank)

16. ABSTRACT (200 words or less)

This report presents the in-reactor data collected from the PNL Halden test assembly IFA-432. The irradiation test is part of an experimental program entit]ed "Experimental Support and Development of Single-Rod Fuel Codes" sponsored by the Fuel Behavior Research Branch of the NRC. The purpose is to reduce the uncertainties of predicting the thermal and mechanical behavior of an operating nuclear fuel rod. Fuel centerline temperatures, cladding elongation, internal fuel rod pressures, and local powers at the thermocouple (TC) positions are shown as a function of time. The local powers were derived from neutron detector readings while the other variables were measured directly. Detailed analysis of the data is not made, but topical reports discussing certain aspects of the data are referenced. Descriptions of the assembly, instrumentation and calibration, and data processing methods are also presented.

17. KEY WORDS ANO DOCUMENT ANALYSIS

17a. DESCRIPTORS

17b. IDENTIFIERS/OPEN-ENDED TERMS

18. AVAILABILITY STATEMENT

Unlimited

\begin{tabular}{|c|c|}
\hline $\begin{array}{c}\text { 19. SE CURITY CLASS (This report) } \\
\text { Unclassified }\end{array}$ & 21. NO OF PAGES \\
\hline 20. SECURITYCLASS (Thus ooge) & $\begin{array}{l}22 \text { PRICE } \\
5\end{array}$ \\
\hline
\end{tabular}


